\author{
Universid Ade De SÃo PaUlo \\ Faculdade de Filosofia, Letras e Ciências Humanas \\ Departamento de Sociologia
}

\title{
O lugar da Nação: estudo da abordagem da Nação no Dual-estruturalismo de Celso Furtado e nos Estudos sobre a dependência de Femando Henrique Cardoso
}

\author{
F ábio Ricardo Kalvan
}

Dissertação de Mestrado apresentada ao Departamento de Sociologia da Faculdade de Filosofia, Letras e Ciências Humanas da Universidade de São Paulo, para a obtenção do título de Mestre em Sociologia, sob a orientação do Prof. Dr. Francisco Maria Cavalcanti de O liveira.

São Paulo

2000. 
A meus pais, por este e outros, muitos outros apoios.

A Patrícia, por tudo e pela paciência. 


\section{AgradeCiMENTOS}

Ao levar adiante o Mestrado e fazer esta dissertação, tornei-me devedor de um bom número de pessoas. Não posso me furtar de mencionar algumas.

Desde um ponto mais recuado no tempo, devo aos professores Laymert Garcia dos Santos, Niuvenius Junqueira Paoli e Josué Pereira da Silva, todos do IFCH/Unicamp, o incentivo para o aprofundamento do estudo da Sociologia e para a muito salutar mudança de ares acadêmicos.

Já no Mestrado, minha maior dívida é com o Professor Francisco de Oliveira, que através de uma orientação segura e tranqüila contribuiu sobremaneira para o aprimoramento de um projeto de pesquisa então bastante incipiente, da mesma maneira que me deu a possibilidade de desfrutar da bagagem teórica e das considerações críticas que só um especialista no tema pode oferecer. Não posso esquecer também dos professores Plínio de Arruda Sampaio Jr., do IE/Unicamp, e Brasílio Sallum Jr., da FFLCH/USP, que por ocasião de meu exame de qualificação teceram críticas preciosas e exortaram-me a entrar decididamente no debate acadêmico (a "entrar na briga") e fazer um trabalho rigoroso. Se consegui incorporar e aproveitar tudo o que me foi dito, tenho minhas dúvidas.

Todavia, no trajeto do Mestrado e da pesquisa as dívidas foram se avolumando, de modo que é impossível agradecer a cada pessoa nominalmente. Nesse rol, devo mencionar os colegas e funcionários do Programa de Pós-graduação em Sociologia da FFLCH/USP. Por outro lado, quero destacar os colegas, agora amigos, do Programa de Formação de Quadros Profissionais (os "bolsistas") do Centro Brasileiro de Análise e Planejamento (Cebrap), anos 1999 e 2000. Mesmo sem o saber, eles colaboraram imensamente por meio da experiência ímpar e extremamente frutífera de um grupo multidisciplinar em que a regra é o ambiente de discussões, debates e seminários coletivos. Meu crescimento intelectual ali 
foi notável, crescimento que de alguma maneira se reflete (espero) nesta dissertação. Este obrigado é extensivo aos pesquisadores, funcionários e pessoas outras com quem tive contato no Cebrap. Por fim, sou devedor também dos amigos de Campinas e, sobretudo, dos de Paulínia.

A todos gostaria de agradecer indistintamente, se não na medida em que devo, ao menos na que posso.

$$
* * *
$$

A pesquisa de que esta dissertação é resultado contou com o imprescindível apoio financeiro, primeiro, do Conselho Nacional de Desenvolvimento Científico e Tecnológico (CNPq) e, depois, da Fundação de Amparo à Pesquisa do Estado de São Paulo (Fapesp). 


\section{SUMÁRIO}

Capítulo 1 - A defesa da nação: Celso Furtado E a superação do SUBDESENVOLVIMENTO

Considerações preliminares

A interpretação do subdesenvolvimento $\quad 20$

Subdesenvolvimento versus Nação _.................................... 31

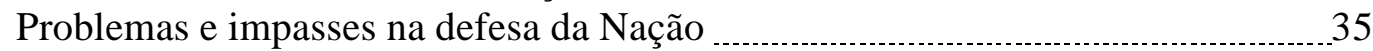

CAPítulo 2 - A SUbordinaÇÃo da NaÇão: FERnANdo Henrique Cardoso E A MANUTENÇÃO DA DEPENDÊNCIA

Revisões do dual-estruturalismo e origens dos estudos sobre a dependência _ $\quad 47$

Do subdesenvolvimento à dependência: política e economia em primeiro plano 54

Desaparecimento dos obstáculos internos e externos: sociedade nacional apesar da dependência 65

CAPÍTULO 3 - SUBDESENVOLVIMENTO, DEPENDÊNCIA E DESENVOLVIMENTO NACIONAL

A Nação entre o subdesenvolvimento e a dependência 82

A distinção reeditada: Nação, subdesenvolvimento, dependência e globalização 91 


\title{
RESUMO
}

Este trabalho aborda as interpretações de Celso Furtado e de Fernando Henrique Cardoso a respeito do desenvolvimento capitalista brasileiro. O objetivo é ver como cada autor incorpora e lida com a idéia de Nação — sociedade nacional, Estado nacional - e que importância confere a ela em suas análises. Nesse sentido, trata-se de comparar como a Nação é entendida em sua relação com a noção de subdesenvolvimento (Furtado) e com a noção de dependência (Cardoso). O que fica evidenciado é que, enquanto Furtado compreende o subdesenvolvimento como antítese da consolidação nacional, Cardoso sublima esse mesmo antagonismo e julga possível conciliar algum desenvolvimento nacional com dependência. No limite temos que, em Furtado, a consolidação nacional exige a superação do subdesenvolvimento, ao passo que, no caso de Cardoso, uma inserção subordinada do Brasil no sistema capitalista internacional já basta, distinção essa que está refletida nas posições e considerações mais recentes de Furtado e de Cardoso.

Palavras-chave: Celso Furtado; Fernando Henrique Cardoso; subdesenvolvimento; dependência; Nação; desenvolvimento nacional; Brasil; pensamento social brasileiro.

\begin{abstract}
The present text focuses on the Celso Furtado's and Fernando Henrique Cardoso's interpretations about Brazilian capitalist development. It itends to understand how each one of these authors approach the idea of Nation in his works and to compare their views. The main result is that for Furtado Nation and underdevelopment are antagonistic words and realities, so it's necessary to extinguish the underdevelopment, and for Cardoso dependency is not a problem to the national issue and a subordination to the international capitalism is a reasonable way of development.
\end{abstract}

Keywords: Celso Furtado; Fernando Henrique Cardoso; underdevelopment; dependency; Nation; national development; Brazil; Brazilian social thinking. 


\section{INTRODUÇÃO}

Tomando uma observação feita de um ponto de vista mais geral, é possível dizer que, por razões várias, o interesse pela questão do desenvolvimento capitalista brasileiro tem sido retomado ultimamente, seja nos ambientes acadêmicos, seja na sociedade em geral. Embora a explicação desse "renascimento" demande mais espaço do que ora disponível, não podemos deixar de reconhecer que o atual processo de "globalização" pelo qual passa o sistema capitalista internacional desempenha aí papel preponderante; diante de um capitalismo que se financeiriza cada vez mais, que reformula em considerável medida as bases sobre as quais se assentou o período de desenvolvimentos nacionais ( grosso modo, após 1945), que impõe aos Estados nacionais desafios econômicos, políticos e sociais não desprezíveis, diante disso tudo a posição do Brasil nesse torvelinho é de novo centro das atenções. Um país com marcadas desigualdades econômicas e sociais, de tradição políticosocial autoritária, subdesenvolvido e dependente tem chance de se realizar enquanto projeto nacional nessa nova quadra capitalista? Ou, pelo contrário, será justamente esta quadra que abre novas possibilidades de superação das agruras de um país periférico? Internamente, por outro lado e de modo não menos importante, fatores de ordem econômica (os altos e baixos da economia brasileira nas décadas de 1980 e 1990) e político-social (transição democrática, persistência das desigualdades sociais) contribuem para o feixe de motivos que explicam a ressignificação teórica e prática da questão do desenvolvimento capitalista brasileiro.

Naturalmente que o movimento de retomada dos estudos sobre o desenvolvimento capitalista brasileiro não pode ser entendido como uma tentativa direta de responder às indagações formuladas pelo quadro retratado acima, mas é inegável que este é um pano de fundo - às vezes mais, às vezes menos evidente — daquele. De qualquer modo, o que importa ressaltar é que a referida temática vem ganhando força no âmbito acadêmico, o que pode ser visto pela crescente recuperação e análise crítica de um período extremamente fértil da produção das Ciências Sociais brasileiras e latino-americanas, que vai dos anos 
1950 até início dos anos 1980, aproximadamente. Período no qual o tema em voga era precisamente o desenvolvimento nacional: sua caracterização, sua explicação, diagnósticos e prognósticos. Período no qual são lapidadas as noções (ou se se quiser, dos conceitos) do Brasil como um país subdesenvolvido ou dependente, expediente pleno de significado: primeiro porque não se tratava da mera importação de esquemas analíticos prontos, no mais das vezes de molde neoclássico, mas sim da construção de um arcabouço interpretativo original, criativo e rigoroso que desse conta das especificidades regionais; depois porque se tratava de compreender e registrar a especificidade do trajeto e do traquejo do desenvolvimento capitalista brasileiro (e latino-americano, no geral) no bojo do sistema capitalista internacional, distinguindo-o qualitativamente do que ocorreu com os países centrais. Marca maior deste período e da produção teórica daí derivada é a Comissão Econômica para a América Latina e Caribe (Cepal): ali é que foi forjada quiçá a primeira explicação precisa e articulada - um pensamento mesmo - sobre o desenvolvimento capitalista desta região e que foi largamente utilizada e ensejou desdobramentos posteriores vários.

Assim, o estudo da Cepal ou então daquilo que escreveram Raúl Prebisch, Caio Prado Júnior, Celso Furtado, Fernando Henrique Cardoso, Rui Mauro Marini, Theotônio dos Santos, Florestan Fernandes etc. e das linhas de pensamento a que deram origem não deixa de ser uma maneira de retratar e questionar a produção brasileira e latino-americana daquele período, recuperando-a e submetendo-a a análises detidas, a enfoques que privilegiam este ou aquele aspecto, a comparações. E, no fundo de tais tarefas, a pretensão maior de compreender melhor o Brasil, a América Latina e sua démarche capitalista. É esse movimento, pois, que parece estar ganhando impulso hoje nos círculos acadêmicos nacionais através de discussões, palestras, debates, artigos, dissertações, teses e livros.

Esta dissertação é (ou pretende ser) uma peça neste fluxo. Ela versa sobre o referido período áureo das Ciências Sociais nacionais, porém como não é possível abarcar toda a imensidão do tema, restringe-se a um trecho específico: as interpretações que, de um lado, Celso Furtado e, de outro, Fernando Henrique Cardoso ofereceram e oferecem do desenvolvimento capitalista brasileiro, o primeiro através de seu "dual-estruturalismo", o segundo constituindo uma das vertentes daquilo que depois ficou conhecido como "teoria da dependência" (ou "estudos sobre a dependência", como se verá adiante). De novo, em 
vista da envergadura do pensamento de cada um deles, a mira deste trabalho está num aspecto dado e preciso: o lugar que a Nação — sociedade nacional, Estado nacional — tem nas interpretações de Furtado e de Cardoso. O objetivo aqui é, portanto, buscar ver como cada autor referido opera em seu pensamento a questão da Nação e, feito isso, comparar tais perspectivas entre si, retirando daí algumas considerações. Nesse sentido, este não é um trabalho monográfico, que pretende dar conta do pensamento de um autor, mas sim que tenciona, partindo de uma visão geral sobre o que Furtado e Cardoso escreveram e pensaram, salientar e comparar um ponto determinado, qual seja, o lugar da Nação. Está visto que não se trata de investigar o que cada autor entende como Nação nem de, a partir de uma definição que sirva de parâmetro, dizer que o entendimento deste ou daquele está mais correto ou mais incorreto, mas sim apenas de comparar como um e outro vê e equaciona a "questão nacional" na problemática do desenvolvimento capitalista brasileiro. Numa palavra, ver como a Nação é incorporada na noção de subdesenvolvimento e na de dependência.

Para tanto, as obras de Furtado e de Cardoso são tomadas em blocos, sem dar maiores atenções para nuanças e variações no interior de cada uma delas. No caso de Furtado, embora as obras do chamado "auge do desenvolvimentismo" (1950-1964) tenham peso destacado, escritos posteriores são igualmente incorporados, mesmo porque acentuam ou ajudam a esclarecer pontos recorrentes da interpretação furtadiana. Para Cardoso, parto de seu trabalho conjunto com Enzo Faletto (de 1969) e passo a seus trabalhos posteriores, tanto aqueles dedicados a reafirmar suas posições originais quanto aqueles visando a criticar a "corrente marxista" da teoria da dependência.

Assim, o primeiro capítulo da dissertação é dedicado a Celso Furtado e a sua noção de subdesenvolvimento. Como será visto, a Nação é a preocupação precípua de Furtado, como o demonstra a centralidade das idéias de desenvolvimento nacional e integração nacional. Deste ponto de vista particular, não há como não reconhecer que ele se inscreve na linhagem de autores como Caio Prado Júnior, Sérgio Buarque de Holanda e Gilberto Freyre, pois, para além de seus temas específicos, é para a formação do Brasil enquanto Nação que todos eles estão olhando. Quanto ao subdesenvolvimento, Furtado o caracteriza como um desenvolvimento capitalista sui generis, que segue caminho diverso daquele dos países capitalistas centrais e que destila uma série de efeitos deletérios e estruturais na 
economia e na sociedade brasileiras, inclusive o de fazer com que apenas uma pequena parcela da população opine e usufrua da utilização do excedente econômico aqui produzido. Ou seja, o subdesenvolvimento é um processo que nasce e se mantém graças, entre outros motivos, à "privatização dos benefícios" e à "socialização das perdas" da atividade econômica nacional levados adiante por uma parcela ínfima da população. Daí é que, para Furtado, a superação do subdesenvolvimento faz-se necessariamente pela construção e consolidação nacional ou, inversamente, a constituição efetiva da Nação somente pode se dar se desatadas as amarras do subdesenvolvimento. Nação e subdesenvolvimento são, pois, termos antagônicos na interpretação de Furtado.

Em sequiência, o segundo capítulo da dissertação tem como objeto o pensamento de Fernando Henrique Cardoso. Partindo de uma crítica às "promessas não cumpridas" pelo desenvolvimentismo e da indagação das razões desse descumprimento, Cardoso - a princípio junto com Faletto - indica a necessidade de compreender o processo de desenvolvimento como, de um lado, político e econômico a um só tempo e, de outro, simultaneamente condicionado externa e internamente. Daí que a noção de dependência seria mais adequada, ainda segundo Cardoso, para perceber aquilo que o pensamento cepalino-furtadiano não houvera entendido, que o capitalismo entrava em nova fase, na qual as oposições de interesses capitalistas centrais e periféricos assumiam ares mais articulados. Ora, é nessa articulação que Cardoso vê a possibilidade de, apesar da dependência, lograr algum desenvolvimento; ou seja, mesmo sob os auspícios da dependência, o Brasil pode se desenvolver nalguma medida - ter um "desenvolvimento dependente-associado". A questão aqui é que existe sim a idéia de Nação no esquema analítico de Cardoso, como ele mesmo frisa, porém nem essa Nação é um empecilho à dependência nem a dependência impede o caminho da sociedade nacional. No pensamento de Cardoso, portanto, Nação e dependência são termos que não conflitam.

Diante do exposto nos dois primeiros capítulos, o terceiro resume-se a retirar algumas considerações do lugar da Nação em cada um dos autores examinados. De modo geral, o que procuro indicar é que, enquanto a interpretação de Furtado a respeito do desenvolvimento capitalista brasileiro pode ser compreendida como uma teoria da consolidação da Nação pela superação do subdesenvolvimento, a interpretação de Cardoso pode ser lida como uma teoria da acomodação subordinada da Nação no sistema capitalista 
internacional. Ou seja, de Furtado a Cardoso há uma diferença de radicalidade quanto ao lugar da Nação que é notável. Daí que, entre continuidades e rupturas que há entre um e outro, esta é decerto um dos maiores pontos de distanciamento entre eles. Essa percepção é examinada também e por fim nos escritos e abordagens mais recentes que os referidos autores têm feito sobre o Brasil diante da "globalização". Tentando respeitar o estatuto do discurso de cada um - um ainda mais acadêmico, outro envolvido no mundo políticopartidário —, penso que fica evidente que tais posições atuais são alimentadas pelas respectivas interpretações originais; ou seja, Furtado ainda deposita grande ênfase no fortalecimento da Nação como escudo contra as injunções do capitalismo internacional e Cardoso vê na globalização a chance de pôr o Brasil, ainda que subordinadamente, em sintonia com os países capitalistas centrais. É preciso reconhecer pois que, para o bem ou para o mal, há considerável continuidade e coerência na trajetória de nossos autores estudados.

É importante voltar a dizer que, com esta dissertação, não tenho a mínima pretensão de esgotar o tema ou o pensamento de Furtado e de Cardoso neste aspecto preciso. Quero tão-somente abordar um ponto estrito e, com isso, tentar compreender e talvez contribuir nalguma medida para a compreensão do período da produção das Ciências Sociais brasileiras e latino-americanas em que o desenvolvimento capitalista da região ocupou de modo notável o centro das atenções. Essa é a pretensão mais imediata que me anima, se bem que, reconheço, fazendo isso procuro tentar compreender os meandros do próprio Brasil, ontem e hoje. 


\section{Capítulo 1 \\ A defeSa da NAÇão: Celso Furtado e a SUPERAÇÃO DO SUBDESENVOLVIMENTO}

\section{Considerações preliminares}

Antes de entrarmos em definitivo na questão que é propriamente a deste capítulo a saber, a teorização furtadiana sobre o subdesenvolvimento (sobretudo o brasileiro) e as possibilidades de superação deste subdesenvolvimento, processo no qual a Nação ocupa lugar de destaque —, convém abordar alguns pontos que servem para esclarecer melhor o pensamento de Celso Furtado, nuançando-o.

O período compreendido entre os anos 1940 e 1970 foi de uma produção ímpar nas Ciências Sociais latino-americanas, quando germinaram e consolidaram-se ali esquemas teóricos e analíticos que alcançaram inaudita repercussão regional e mundial. Penso na Comissão Econômica para a América Latina e Caribe, a Cepal, órgão ligado à Organização das Nações Unidas e situado no Chile, que reuniu intelectuais da envergadura de Aníbal Pinto, Juan Noyola, José Medina Echevarría, Aníbal Quijano, Raúl Prebisch — seu mais prestigiado diretor - e o economista brasileiro Celso Furtado, entre outros. O objetivo mais primordial da instituição, este é conhecido: através do "dual-estruturalismo" compreender e questionar o desenvolvimento capitalista da América Latina, tentando mesmo influir em seus caminhos. Nessa tarefa é que se consubstanciou o chamado “pensamento cepalino", para o qual Furtado tanto contribuiu quanto representou tão bem.

Não foram poucos os temas sobre os quais debruçou-se Furtado: questões sobre as economias brasileira e latino-americana; também questões outras como, por exemplo, sobre as relações entre teoria e prática, sobre mudança social e política, sobre o planejamento econômico, sobre as relações entre Estado e economia, sobre o papel dos intelectuais no 
mundo (especialmente no mundo subdesenvolvido) etc. (Cepêda, 1998: 06). No entanto, a pedra de toque de Furtado, quer dizer, a liga que unifica sua obra, está antes de tudo na questão do desenvolvimento capitalista no Brasil — ou melhor, do subdesenvolvimento e de sua inserção, enquanto parte do mundo periférico, no movimento mais amplo do sistema capitalista internacional, ou, de modo mais geral mas que vem a dar no mesmo, a formação econômica do Brasil. Essa constatação tem a virtude de apontar um aspecto de monta: que as análises econômicas de Furtado não se efetivam a desmedro de elementos políticos e sociais, pelo contrário requerem este arcabouço mais amplo. Nesse sentido, é mister reconhecer que no Furtado economista há um pensador político e social ${ }^{1}$; como se verá, em seu pensamento os aspectos econômicos, políticos e sociais informam-se reciprocamente, às vezes como virtude, outras como pecado. Daí que o analista que quiser conhecer melhor as idéias de Furtado terá necessariamente que vencer uma primeira barreira, aquela levantada pelo linguajar econômico do qual o economista brasileiro se serve. Não que ele acredite numa suposta supremacia das categorias econômicas, mas é que ali está a âncora teórica e conceitual que lhe permite interpelar e interpretar o Brasil e o mundo.

Está visto que, diante de tal variedade e complexidade de temas, este capítulo da dissertação não quer reproduzir e, muito menos, dar conta de todos eles. O centro do trabalho é mais preciso: procurar ver como Furtado entende o desenvolvimento capitalista brasileiro e tentar indicar que nesse processo a Nação tem assento especial; quer dizer, a intenção aqui é apontar que a interpretação que Furtado oferece do desenvolvimento capitalista nacional confere importância e busca implementar a construção nacional, o que, pelo que veremos, implica numa necessária superação do nosso subdesenvolvimento. Noutras palavras, subdesenvolvimento e construção nacional (ou Nação) são termos incompatíveis. Para tanto, faço uso tanto da primeira fase da produção furtadiana, aquela em que a análise do subdesenvolvimento é originalmente estruturada e que engloba o período de 1950 a 1964, que C. Mallorquín chama de "apogeu e declínio do discurso

\footnotetext{
${ }^{1}$ Algumas interpretações têm a qualidade, à parte os resultados a que chegam, de indicar as "raízes políticas" do pensamento furtadiano, como, por exemplo, Cepêda (1998), Moraes (1995) e Oliveira (1997). Para que fique desde já esclarecido para este capítulo e os subseqüentes, as citações retiradas de títulos em outros idiomas que não o português têm a minha tradução.
} 
desenvolvimentista" (Mallorquín, 1993: VIII)², quanto de livros gerados depois, que expandem aquela análise. Voltarei às obras mais recentes, as produzidas nos anos $1990 \mathrm{em}$ diante, no final da dissertação, justamente para ver como a questão da Nação ainda é relevante para Furtado, ainda mais diante das últimas transformações do sistema capitalista internacional.

Ora, para aquilatar devidamente o pensamento de Furtado, é valioso verificar em que fontes o economista brasileiro bebeu suas principais influências e contra quais interlocutores ele se contrapôs. Vejamos isso.

\section{Algumas influências e a Cepal}

Que a Nação — ou a sua formação — está na dianteira do pensamento de Furtado é fato certo e que veremos adiante mais detalhadamente. Por isso, por pensar na esteira da tradição das grandes explicações à escala de Gilberto Freyre, Caio Prado Júnior e Sérgio Buarque de Holanda, é que Furtado, sem favor algum, pode ser tomado como legítimo um "penseur" (Pécault, 1998), isto é, como um pensador preocupado nada menos com a explicação do Brasil por inteiro. Todavia, diversamente de seus antecessores, Furtado recorreu a uma linguagem nova - à economia política —, até então pouco usada, para tentar compreender o processo histórico-social de formação do Brasil. Esse expediente é interessante, dentre outros motivos, por deixar de lado interpretações de cunho biológico, racial, climático etc. em favor de uma explicação racional e objetiva da estrutura social, política e econômica do país. E já aqui a reverberação em Furtado do pensamento da Cepal é patente: é na economia que se vai buscar explicações para o "atraso" brasileiro e latinoamericano.

\footnotetext{
${ }^{2}$ Além dessa primeira fase, Mallorquín anota duas outras: uma, de 1964 a 1975, que marca a incursão acadêmica e a procura de novas respostas à situação de regimes ditatoriais pela qual a América Latina passava na época; e outra, de 1975 a 1992 (que é o último ano que a análise de Mallorquín contempla), marcada pelo esforço tentativo de reconstrução teórica do estruturalismo e retorno à vida pública
} 
"Pode-se dizer, portanto, que Prebisch e a Cepal estão entre os principais construtores de uma linhagem interpretativa que afirma a centralidade do econômico na construção das nações latinoamericanas";

Donde que o prestígio desta interpretação espalhou-se:

“A especificidade latino-americana não era mais procurada no racial, em fatores climáticos e geográficos, no cultural, no caráter do povo ou mesmo no social, como o fora até anteriormente. (...) Esse enfoque 'culturalista' foi praticamente esquecido, como uma fase ultrapassada ou muito particular do pensamento brasileiro, e o enfoque centrado no economicismo tornou-se o discurso 'natural' para a análise da sociedade". (Macedo, 1994: 62).

É justamente este o trunfo de Furtado na interpretação da formação do Brasil: a tentativa de descer à estrutura econômica do Brasil com vistas a acompanhar de que maneira e por quais motivos nosso processo histórico-social assume a forma do subdesenvolvimento. Mas na "fermentação" desta perspectiva são várias as influências. Fiquemos apenas com as mais essenciais.

Uma figura cuja presença é marcante no eclético instrumental teórico de Furtado (Sampaio Jr., 1997: 76) é Max Weber. Disso é exemplo a constante preocupação furtadiana com a racionalidade dos processos econômicos — ou então com a falta de racionalidade nesses processos, como é o caso dos países subdesenvolvidos como o Brasil. Aliás, é precisamente a irracionalidade do desenvolvimento capitalista no Brasil que engendra e mantém o subdesenvolvimento. Sobre a centralidade da racionalidade na interpretação de Furtado, Sampaio Jr. escreve que

“(...) o objetivo de Furtado é elucidar a 'racionalidade econômica' que preside o processo de industrialização - a espinha dorsal dos sistemas econômicos nacionais (...) A análise de Furtado é um esforço de revelar a 'irracionalidade' deste processo [de subdesenvolvimento] como meio de impulsionar a construção da Nação” (Sampaio Jr., 1997: 76-77 e 205). 
Nesse sentido, a resolução do subdesenvolvimento significaria, para Furtado, a quebra da referida irracionalidade econômica e a sintonização do Brasil com o processo de racionalização do mundo, tão bem estudado por Weber. ${ }^{3}$

Uma outra influência, um tanto ligada a essa de Weber, vem de Karl Mannheim e expressa-se na idéia notadamente furtadiana da intervenção urgente e necessária do intelectual na realidade, da capacidade desse intelectual de alçar-se por sobre a realidade para ver melhor e para escapar às injunções políticas e sociais diversas e, por fim, na idéia do planejamento econômico ${ }^{4}$. Esse "mannheimianismo" de Furtado fica evidente quando ele escreve sobre a reconstrução da Europa após 1945, a que ele assistiu:

\begin{abstract}
"Como estudioso de Mannheim, estava convencido de que um amplo esforço de reconstrução institucional tornava-se indispensável, se o objetivo era preservar a liberdade do homem. Cabia prevenir as crises e neutralizar os efeitos da instabilidade inerente às economias de mercado (...) A solução estava na introdução de uma dupla racionalidade, ao nível dos fins e dos meios, o que exige a planificação. Meus estudos de organização das atividades do setor público, com base em autores norte-americanos e as idéias de Mannheim em seu Man and society in age of reconstruction (...), haviam moldado minha visão das opções com que se defrontava a Europa em reconstrução" (Furtado, 1985: 17).
\end{abstract}

Quer dizer, Furtado vê claramente a possibilidade de colocar-se a serviço de algo acima dos interesses particulares e de classe, isto é, a serviço dos "interesses da Nação" 5.

Uma outra natureza do pensamento furtadiano, que é fortíssima, é a de ser um efeito direto da "revolução keynesiana". Num mundo ainda marcado pela crise de 1929 e dilacerado pela experiência da Guerra, em que a doutrina do laissez-faire estava em franco descrédito e se lhe debitava grande parte de culpa das agruras daquele momento, o aporte de J. M. Keynes era extremamente sedutor, tanto mais para aqueles que igualmente

\footnotetext{
${ }^{3}$ Sobre esse assunto, não é demais lembrar que Furtado foi, no início de sua carreira, um técnico do DASP (Departamento de Administração do Serviço Público), experiência que certamente marcou-o muito, especialmente no papel a ser desempenhado pelo Estado. Em seu alentado estudo sobre Furtado, Mallorquín (1993) indica dois artigos desse período: "A estrutura da Comissão do Serviço Civil dos Estados Unidos". Revista do Serviço Público, ano VII, vol. I, n. 2, 1944; "Notas sobre a administração de pessoal no governo federal americano". Revista do Serviço Público, ano VII, vol. III, nº 1, 1944.

4 "Do ponto de vista do planejamento, a perspectiva de Mannheim vem a ser particularmente útil a Furtado" (Santos*, 1998: 59). O “*” que segue a referência a "Santos" aparecerá sempre para distinguir Maria Odete Santos de Theotônio dos Santos; o que ocorre é que ambos têm textos de 1998, assim sempre que aparecer "Santos*”, refiro-me a Maria Odete Santos. Esta distinção aparecerá também nas referências bibliográficas ao final deste trabalho.

5 "Seguindo a Mannheim, eu tinha uma certa idéia do papel social da Intelligentsia, particularmente nas épocas de crise. Sentia-me acima dos condicionantes criados por minha inserção social e estava convencido de que o desafio consistia em instilar um propósito social no uso dessa liberdade" (Furtado, 1985: 18). Sobre a atividade de Furtado enquanto homem de ciência que encara tarefas públicas, veja Iglésias (1971: 159-231).
} 
recusavam o radical caminho da revolução ou os excessos do marxismo tornado pobre e mecânico (Chilcote, 1983). De Lord Keynes Furtado — assim como a Cepal — retém a premência do controle das forças econômicas, que não poderiam ser deixadas ao livre talante dos mecanismos do mercado e que deveriam ser direcionadas em benefício da preservação e do incremento da atividade econômica, tarefas delegadas, como é bem sabido, ao Estado e ao investimento público ${ }^{6}$. Será pois com esses olhos, assumidamente heterodoxos, que Furtado interpretará o Brasil e prognosticará medidas corretivas, como Formação econômica do Brasil, de 1959, cristaliza muito bem (Oliveira, 1983).

É certo, no entanto, que as influências de Furtado não provêm só do exterior. Dos grandes pensadores brasileiros ele não deixou de assimilar algo, como por exemplo de Sérgio Buarque de Holanda e de Gilberto Freyre (Furtado, 1992c; 1998: 09-10). Já o caso de Caio Prado Jr. é específico: se reconhece nele méritos historiográficos, aponta insuficiências do ponto de vista econômico que engessariam a análise. Embora não assuma (Caio Prado simplesmente não é citado em Formação econômica do Brasil), a questão é que o parentesco entre o tratamento que Furtado dá ao Brasil colonial e os trabalhos de Caio Prado sobre o mesmo assunto é muito evidente, deixando claro, como Cepêda indica, que o primeiro é descendente teórico e intelectual do segundo (Cepêda, 1998: 52 e ss.) ${ }^{7}$.

A lista de influências maiores ou menores de Furtado poderia continuar, mas o que foi escrito é quanto nos basta, tanto mais porque, ainda que outras fossem aqui agregadas, serviriam para demonstrar o mesmo ponto, isto é, como o pensamento furtadiano serve-se de diversos elementos para angariar um arsenal teórico considerável e armar uma perspectiva eclética sobre o desenvolvimento capitalista brasileiro e mesmo para inaugurar uma economia política brasileira ${ }^{8}$. Uma dessas matrizes, porém, deve ganhar destaque especial, primeiro porque fornece as bases sobre as quais Furtado monta sua análise do subdesenvolvimento brasileiro e, segundo, porque adianta já ali aquilo que interessa ressaltar em Furtado, vale dizer, a idéia de que a construção da Nação passa forçosamente pela superação do subdesenvolvimento. Refiro-me à Cepal. É na Cepal que as influências

\footnotetext{
${ }^{6}$ Sobre a influência de Keynes em Furtado, veja Guimarães (1999: 60-71 e 100-113) e Reino (1994: 19-20).

${ }^{7}$ Sobre o assunto pode-se consultar Bielschowsky (1996: 132-179), Guimarães (1993: 13-42) e Mallorquín (1993: capítulos 1 e 3). Já o artigo de Oliveira (1997) tenta indicar a existência de um "diálogo não escrito" entre Furtado e os clássicos do autoritarismo brasileiro (Oliveira Vianna e Alberto Torres, basicamente).
} 
várias de Furtado vão ganhar forma e força para a consolidação de seu esquema interpretativo e para a defesa da Nação contra o subdesenvolvimento, tanto no campo da teoria quanto, sobretudo, no da prática.

Seguramente a Cepal não foi a primeira a falar em subdesenvolvimento, porém contribuiu em larga medida para que este termo alcançasse rigor de conceito. O processo de descolonização iniciado no pós-Segunda Guerra Mundial vem reforçar algo que então vai ganhando aspecto de certeza, que vários países estavam livres porém pobres, o que vale dizer que a igualdade política de pouco valeria se não fosse acompanhada de modificações também na distribuição hierarquizada das riquezas das Nações. Dizendo com outras palavras, a referida descolonização acabou por deixar mais evidente uma preocupação existente desde antes de 1945 com o atraso econômico de alguns países. Surgem assim as primeiras reflexões sobre as Nações subdesenvolvidas e a concepção do desenvolvimento nacional como necessária superação do atraso econômico (Cepêda, 1998: 145) ${ }^{9}$. Nesse sentido, economistas como P. Rosenstein-Rodan e H. Singer, ligados à Comissão Econômica para a Europa, são alguns dos estudiosos que, de alguma maneira, chegaram à idéia de subdesenvolvimento — no caso deles, voltada à situação específica de países como Portugal, Espanha e Grécia (periféricos diante de uma vizinhança que estava "dando certo" $)^{10}$. Do mesmo modo os trabalhos de R. Nurkse e G. Myrdal, que também perseguem explicações alternativas (não neoclássicas) para o atraso econômico de certos países e para a quebra do "círculo vicioso da pobreza" (Mantega, 1995: 50-57; Myrdal, 1960, 1962; Nurkse, 1970). Ora, é dessa ambiência que provém a Cepal ${ }^{11}$.

\footnotetext{
8 “(...) pode-se dizer que a economia política brasileira passa a existir efetivamente, enquanto ciência sistemática e abrangente, munida de um arcabouço teórico específico para interpretar a dinâmica da economia brasileira, com a obra de Celso Furtado". Mantega (1995: 87).

${ }^{9}$ Sobre isso Belluzzo diz que, naquele momento pós-1945, "A concepção de um desenvolvimento nacional, no marco de uma ordem internacional estável e regulada, não era uma fantasia idiossincrática, mas decorria do 'espírito do tempo', forjado na reminiscência da experiência terrível das primeiras quatro décadas deste século. Tampouco era fortuito o papel atribuído à ação do Estado no estímulo ao crescimento, na prevenção das instabilidades da economia e na correção dos desequilíbrios sociais” (Belluzzo, 1995: 12).

${ }^{10}$ Aliás, é interessante não esquecer que Singer e Prebisch formularam praticamente ao mesmo tempo a chamada "teoria da deterioração dos termos de troca", por isso também conhecida como teoria SingerPrebisch. Os textos em que tal teoria está lançada são, de Singer, "The distribution of gains between investing and borrowing countries", e de Prebisch, El desarrollo económico de América Latina y algunos de sus principales problemas, ambos de 1950 (Gurrieri, 1982: 48 e ss.).

11 "O surgimento daquilo que comumente se denomina 'pensamento econômico da Cepal' coincide, no tempo, com os ventos democratizantes que varreram o mundo no imediato pós-guerra de 1945, ventos esses que precipitaram a queda de várias ditaduras em muitos países, bem como o início do desmantelamento de vários regimes coloniais até ali solidamente estabelecidos" (Figueiredo, 1990: 138). De modo similar, R. M.
} 
$\mathrm{O}$ pensamento cepalino estrutura-se, portanto, nesse período fértil ${ }^{12}$ e como mais uma tentativa de compreensão não ortodoxa das "sociedades atrasadas". Mas o que há nesse pensamento cepalino afinal e que Furtado utilizará como base de sua interpretação do desenvolvimento capitalista brasileiro?

Parece-me que aqui estamos pisando terreno razoavelmente conhecido e explorado (Rodríguez, 1981 e 1988; Cardoso, 1993: 27-80; Mantega, 1995: 32-48; Moraes, 1995), mas convém ver mais detidamente os pontos principais do pensamento cepalino porque fazendo isso estaremos avançando no pensamento do próprio Furtado. Desta feita, devemos nos ater às duas idéias-força sobre as quais e em torno das quais o pensamento da Cepal se fundamenta: a "teoria da deterioração dos termos de troca (ou intercâmbio)" e o "sistema centro-periferia" 13 .

Em linhas bastante gerais, a teoria (ou se se preferir, "tese") da deterioração dos termos de troca (Rodríguez, 1981: 51-66) procura ser a contraposição à teoria das vantagens comparativas, segundo a qual ao longo do processo de trocas internacionais haveria a distribuição mais eficiente dos frutos do crescimento econômico: haveria aqueles países cujas vantagens comparativas repousariam na produção agrícola, enquanto outros estariam naturalmente destinados à produção industrial; as diferenças entre uma atividade e outra não representariam problemas, pois o emprego de quantidades diferentes de capital, as produtividades diversas, as rendas distintas, tudo isso acabaria sendo equiparado pelo movimento do mercado e o resultado seria a confirmação da tendência ao equilíbrio econômico, em que todos receberiam seu justo quinhão do produto geral. A consideração subjacente a esta teoria é a de que os países não precisam transformar suas estruturas produtivas, antes todos lucrarão se os países agro-exportadores dedicarem-se com denodo a sua atividade e se os países industriais executarem bem o que sabem. Ora, no entender da Cepal o que ocorre é que nas relações internacionais de comércio, ao fim e ao cabo, os

Marini diz: "Essa teoria teria, então, um propósito definido: responder à inquietude e à inconformidade manifestadas pelas novas nações que emergiam à vida independente, à raiz dos processos de descolonização, ao dar-se conta das enormes desigualdades que caracterizavam as relações econômicas internacionais" (Marini, 1994: 136).

${ }^{12}$ Sobre a história da Cepal, Furtado (1985 e 1989) e Hodara (1987) são indicações suficientes.

${ }^{13}$ Pode-se dizer que há dois textos seminais que marcam o "nascimento" da Cepal e nos quais as referidas idéias estão originalmente contidas: El desarrollo económico de América Latina y algunos de sus principales problemas e Estudio económico de América Latina, 1949, ambos escritos por Raúl Prebisch (1982). Sobre o caráter fundador destes textos para a interpretação da América Latina, veja Macedo (1994: 15-19). É de se 
países industriais desfrutam de muito mais capacidade e muito mais poder de reter rendas que os países primário-exportadores; e importante, isso se dá não somente por conta dos méritos próprios do centro capitalista, que possui um grande potencial científico e tecnológico (daí maiores produtividades), mas também e em larga medida através da transferência de rendas da periferia para o centro capitalista. Ou seja, o progresso e o desenvolvimento do centro fazem-se às expensas dos países exportadores de produtos primários — um achado que, pode-se inferir, tem um significado político imenso. É todo um processo de múltiplas faces que causa a maior capacidade de retenção do excedente econômico pelos países centrais: no centro capitalista a mão-de-obra é marcada por uma imobilidade relativa, ao contrário da periferia, o que faz com que os aumentos de rendas tenham que ser mais bem distribuídos, haja vista o maior poder de pressão desses trabalhadores; em decorrência disso, nos momentos de alta dos ciclos expansivos, os trabalhadores e os capitalistas do centro conseguem reter mais rendas, processo que não é proporcional nos ciclos recessivos, isto é, no centro capitalista ganha-se mais na expansão e perde-se menos na recessão; do ponto de vista tecnológico, os produtos da periferia só têm a perder, pois o progresso técnico joga a favor dos produtos manufaturados, seja porque a demanda de produtos primários tem pouca elasticidade (a elasticidade-renda: o consumo de produtos primários aumenta menos que os aumentos de renda), seja porque muitos deles vão sendo substituídos por produtos sintéticos; por fim, sempre há as políticas de taxação alfandegária deliberadamente adotadas pelo países centrais (Prebisch, 1982,passim). Sobre isso escreve Gurrieri:

\footnotetext{
"Em síntese, os centros são capazes de impulsionar incrementos de produtividade muito superiores aos da periferia por seu potencial científico-técnico e de acumulação de capitais; especializam-se na produção daqueles bens que têm uma demanda crescente em relação com a renda; controlam o dinamismo econômico pela posição de liderança que ocupa a demanda de bens industriais em relação com a dos primários; possuem uma estrutura econômico-social que favorece a capacidade de retenção por seus agentes econômicos em relação com os da periferia devido a sua maior homogeneidade e diversificação produtiva e superior organização empresarial e sindical e, finalmente, aplicam medidas diretas para proteger seu nível de renda da competição externa" (Gurrieri, 1982: 25-26).
}

ressaltar que os textos tiveram viva repercussão no Brasil, sendo que o primeiro deles saiu aqui ainda em 1949 na Revista Brasileira de Economia (ano 3, n⿳. 3) por conta da tradução e do empenho de Furtado. 
Ou seja, o mundo equilibrado, estável e equânime preconizado pela teoria econômica liberal revela-se hierarquizado, concentrado e assimétrico e as vantagens comparativas, estas metamorfoseiam-se em "desvantagens reiterativas" (Oliveira, 1983: 08). Assim diz o próprio Prebisch:

\begin{abstract}
"A falha desta premissa [das vantagens comparativas] consiste em atribuir caráter geral ao que em si é muito circunscrito. Se por coletividade só se entende o conjunto dos grandes países industriais, é certo que o fruto do progresso técnico se distribui gradualmente entre todos os grupos e classes sociais. Mas se o conceito de coletividade também se estende à periferia da economia mundial, aquela generalização carrega em si um grave erro. As ingentes vantagens do desenvolvimento da produtividade não têm chegado à periferia em medida comparável à que tem logrado desfrutar a população desses grandes países. Daí as diferenças, tão acentuadas, nos níveis de vida das massas destes e daquela, e as notórias discrepâncias entre suas respectivas forças de capitalização, posto que a margem de poupança depende primordialmente do aumento na produtividade" (Prebisch, 1982: 99100) ${ }^{14}$.
\end{abstract}

Assim, com a teoria da deterioração dos termos de troca temos identificada a dinâmica do comércio entre os países capitalistas e como aí é produzido e reproduzido o que o pensamento cepalino denomina como "condição periférica". A centralidade desta teoria para a Cepal, bem como sua repercussão para os estudos subseqüentes do subdesenvolvimento, não pode ser subestimada, posto que aí se demarca o território cepalino e é fundada sua genuína pièce de resistence ${ }^{15}$. Como se vê, esta é uma perspectiva pouco idílica das relações internacionais de comércio e, de modo geral, de todo o sistema capitalista internacional, de tal modo que, se levada ao limite, poderia mesmo chegar a questionar este sistema - limite que a Cepal, cordata com o decoro exigido de um órgão da ONU, absteve-se de tocar. Posto isso, convém deixar claro que a tese da deterioração dos termos de troca assume e explicita sua percuciência e relevância se atrelada à outra idéia-força cepalina, o "sistema centro-periferia” (Rodríguez, 1981: 36-50).

De acordo com esta proposição, os países do mundo dividem-se entre um centro capitalista e uma periferia conforme a modalidade de sua inserção na divisão internacional do trabalho, ou seja, nessa ordem, ou como produtores de bens manufaturados dotados de

\footnotetext{
${ }^{14}$ Veja também p. 114 do mesmo texto.

15 “(...) a tese da deterioração do termo de intercâmbio tornou-se a pièce de resistence da teoria cepalina, confrontando-se diretamente com a Teoria Tradicional das Vantagens Comparativas, e fornecendo sólidos subsídios para toda uma vertente teórica de extração marxista que se iria ocupar com o 'intercâmbio desigual"' Mantega (1995: 45). Interessante ressaltar que Mantega assinala a influência da tese cepalina nos trabalhos de André Gunder Frank, Arghiri Emmanuel, Samir Amin, entre outros.
} 
alto conteúdo tecnológico, ou como produtores de artigos primários, produtos naturais em geral. Todavia, até aqui o sistema centro-periferia aparentemente não agrega nada ou não se diferencia da teoria neoclássica do comércio internacional, como a de Paul Samuelson, por exemplo (Mantega, 1995: 34-35). Apenas aparentemente, porque bem analisados todos os termos, há uma distinção angular: a tese cepalina não toma a divisão do mundo entre centro e periferia como uma emanação da vocação natural de cada país nem crê que tal organização da economia internacional termine por satisfazer a todos, mas a vê assimétrica, hierarquizada e eivada de relações de poder que acabam fazendo com que as relações internacionais apresentem-se sob a forma de um estado de coisas que favorece os países centrais a desmedro dos periféricos. Bem entendido isso, já aqui podemos ver que, na perspectiva cepalina e contrariamente à "boa ciência" econômica liberal, a posição dos países da periferia capitalista em relação aos do centro não é uma questão de "retardo" naturalmente determinado num caminho único; pelo contrário, trata-se do resultado do tipo de inserção destes países no sistema capitalista internacional, vale dizer, desde sempre como apêndices numa estrutura cujo movimento beneficia estes países industriais (Cardoso, 1993: 34). Referindo-se a Prebisch, Gurrieri faz considerações licitamente extensivas a todo o pensamento cepalino acerca do sistema centro-periferia:

\footnotetext{
"Em suma, Prebisch considera que, por um lado, o sistema centro-periferia em seu conjunto funciona primordialmente para satisfazer as necessidades e interesses dos centros industriais, nos quais o progresso técnico se originou ou propagou com rapidez; por outro lado, os países periféricos se inserem no sistema na medida em que podem servir àqueles interesses e necessidades, como abastecedores de matérias-primas ou alimentos e receptores de produtos manufaturados e capitais; e finalmente, essa inserção não apenas é insuficiente para equiparar o nível de renda da periferia ao do centro, senão que impõe à estrutura produtiva periférica dois traços negativos — heterogeneidade estrutural [o dualismo] e especialização - como conseqüência da penetração lenta e irregular do progresso técnico. De tudo isso derivam-se três desigualdades principais entre centro e periferia: na posição e função que ocupam dentro do sistema, em suas estruturas produtivas e em seus níveis médios de produtividade e renda" (Gurrieri, 1982: 19).
}

Estamos no coração do pensamento cepalino. Esta perspectiva cepalina representa pois não apenas um modo singular de ver uma realidade, mas sim um modo singular de ver uma realidade singular — modo de ver singular justamente porque a realidade assim o é. Com isso temos o que Rodríguez chama de “concepção originária” ou "inicial” da Cepal, em cuja órbita trafegam raciocínios e conceitos, categorias analíticas e indicações práticas. 
"Esta concepção [originária ou inicial] postula que a economia mundial está composta por dois pólos, o centro e a periferia, e que as estruturas produtivas dos mesmos diferem de modo substancial. A estrutura produtiva da periferia se diz heterogênea, para indicar que nela coexistem atividades onde a produtividade do trabalho é elevada, como no setor exportador, com outras de produtividade reduzida, como a agricultura de subsistência. Ademais, indica-se que dita estrutura é especializada, em um duplo sentido: as exportações se concentram em um ou em poucos bens primários; a diversificação horizontal, a complementaridade intersetorial e a integração vertical da produção possuem escasso desenvolvimento, de tal modo que uma gama muito ampla de bens - sobretudo manufaturas - deve obter-se mediante importações" (...). Assim, pois, os conceitos de centro e periferia não se definem como base em uma diferenciação estática de suas estruturas produtivas, mas envolvem as idéias já assinaladas de interconexão e mudança estrutural. Dito de outro modo: centro e periferia conformam um sistema único, que é dinâmico por sua própria natureza" (Rodríguez, 1988: 57-58 e 59, nessa ordem).

Nesta "concepção originária" assume evidência o traço forte que faz do pensamento da Cepal o ícone do "dual-estruturalismo": uma interpretação que busca na estrutura produtiva da periferia as causas e os efeitos do modus operandi do desenvolvimento capitalista latino-americano. Este aspecto é explorado por Rodríguez:

\begin{abstract}
"Com efeito, essa concepção privilegia as peculiaridades da estrutura produtiva da periferia, entre as quais destaca-se o nível de produtividade do trabalho dos diferentes setores produtivos e o grau de complementaridade existente entre eles; tais peculiaridades definem-se por contraposição com as que possui a estrutura produtiva dos centros, o que implica que, simultaneamente, está sendo definido um sistema, o centro-periferia; a desigualdade é vista como inerente à sua dinâmica: as estruturas produtivas dos dois pólos fazem-se mais amplas e complexas, mas as diferenças entre essas estruturas (e entre os respectivos níveis de renda real média) tendem a perdurar" (Rodríguez, 1981: 235).
\end{abstract}

Dessa condição periférica, que é a de uma estrutura produtiva periférica, derivam efeitos econômicos, políticos e sociais que são nossos conhecidos: a heterogeneidade estrutural, que faz com que, no mesmo país, coexistam setores econômicos e sociais atrasados, voltados basicamente à produção para a subsistência, e setores ditos modernos, dedicados à exportação de produtos primários, separação da qual derivam as camadas populares e as "elites dominantes", as primeiras vivendo do mínimo necessário à sobrevivência e as segundas, com seu padrão de vida e de consumo afinado de acordo com o diapasão europeu e norte-americano - eis o dualismo; a larga desocupação dos "fatores produtivos", quer dizer, abundância de mão-de-obra e de terras, anverso da carência de progresso técnico; em decorrência disso, o desemprego estrutural, a baixa produtividade, 
logo baixa acumulação de excedentes; a má distribuição desse pequeno excedente; o acentuado desequilíbrio externo; e finalmente no campo das relações internacionais a frouxíssima capacidade de pressão da periferia sobre o centro capitalista.

Bem, é evidente que o pensamento cepalino não se detém aí: o arcabouço teórico da Comissão continua — é bem sabido — com a aposta na industrialização deliberada pelo Estado como meio de superar a condição periférica (Rodríguez, 1981: 67-183), com o papel do planejamento econômico (Macedo, 1994: 97) e com a expressão prática do dualestruturalismo em políticas econômicas nacionais em grande parte da América Latina - o desenvolvimentismo (Bielschowsky, 1996) - etc. Porém, para o que fora premeditado o esboço feito é suficiente. É suficiente para demonstrar que a Cepal organiza um engenho teórico inovador, que se põe como cunha entre o mecanicismo determinista do marxismo envelhecido pelo estalinismo e o etapismo a-histórico das conhecidas "teorias da modernização" ${ }^{16}$, inovação que, naturalmente, não passou incólume pelas críticas. E os representantes neoclássicos foram os que fizeram as maiores cargas contra o pensamento cepalino, como por exemplo os economistas G. Haberler e J. Viner (Cardoso, 1993: 40$44)^{17}$. Mas é suficiente sobretudo para apontar um outro aspecto: o de que, bem aquilatado, o pensamento cepalino já nos permite ver que, se o que interessa é o desenvolvimento capitalista nacional, este desenvolvimento somente pode ser levado a cabo se os laços do sistema centro-periferia forem questionados e o mecanismo da deterioração dos termos de troca, desmontado. Ou seja, patenteia-se que a modificação da "condição periférica" (e de suas características, que vimos linhas acima) exige a superação do subdesenvolvimento.

Ora, é justamente este o ponto sobre o qual Furtado labora. A questão do desenvolvimento nacional - entendida como integração social e econômica das diversas

\footnotetext{
${ }^{16}$ Teorias da modernização das quais Rostow (1978) é exemplo máximo.

${ }^{17}$ Um adendo: Cardoso sustenta que, apesar dos equívocos de partida das críticas de Haberler e de Viner e de seu travo abertamente conservador, sobretudo o primeiro toca num ponto de fato discutível do pensamento cepalino: o da sugerida inexorabilidade do fosso entre o centro e a periferia capitalistas, que só se moveria num sentido, o de seu aumento. Para Cardoso, tal inevitabilidade é passível de questionamento, embora essa visão estática e catastrófica só fosse ser plenamente desenvolvida tempos depois, não pela Cepal. Com isso Cardoso deixa implícito que não haveria irredutibilidade ou incompatibilidade entre a periferia e o desenvolvimento capitalista (Cardoso, 1993: 41). Do mesmo modo, Cardoso aponta inconsistências no pensamento cepalino quando ele pretende esclarecer as transferências de ganhos da periferia para o centro; não que a Cepal explique erroneamente, antes não há explicação adequada: faltaria uma análise das relações internacionais de exploração entre países e mesmo no interior de cada país (Cardoso, 1993: 38-39). Ora, será precisamente na prospecção destes flancos deixados desguarnecidos pela Cepal que a "teoria da dependência" na vertente representada por Cardoso medra e procura "superar hegelianamente", segundo o próprio Cardoso, o legado cepalino. Veremos isso mais detidamente no capítulo seguinte.
} 
regiões de um país periférico e como aumento do bem-estar geral — está contida, como vimos, no pensamento cepalino e, mais ainda, está ali contida a percepção de que este desenvolvimento somente será factível se o próprio estatuto periférico dos países latinoamericanos no sistema capitalista internacional for questionado. Furtado toma essa problemática cepalina (mesmo porque ele, como integrante da Comissão, ajudou a discriminá-la) e procura explorá-la ainda mais, alcançando uma noção qualificada de "subdesenvolvimento". Ou seja, os trabalhos da Cepal, que lograram arquitetar uma original e percuciente interpretação econômica da América Latina (talvez possamos dizer que em grande medida a "América Latina" passou a existir com a Cepal ${ }^{18}$ ) dão a base sobre a qual Furtado monta seu esquema analítico: o sistema centro-periferia e a tese da deterioração dos termos de troca estão em Furtado, bem como as consequiências e os desdobramentos que se podem retirar daí; e Furtado mobiliza todos esses elementos - e mais suas outras influências — para tentar desvendar nosso subdesenvolvimento e para propor medidas corretivas, sempre com a idéia da Nação em mente, defendendo-a ${ }^{19}$.

\section{A interpretação do subdesenvolvimento}

\footnotetext{
${ }^{18}$ Diz o próprio Furtado (1995: 98): "Não podemos esquecer que América Latina é uma invenção recente. Havia o pan-americanismo, que era uma coisa de Washington, um sistema para encobrir o domínio norteamericano na América Latina. A idéia, porém, de um sistema econômico da América Latina, com problemas comuns etc., foi algo do pós-guerra", algo do pós-Cepal, acrescento eu.

${ }^{19}$ É óbvio que os serviços da Cepal não cessaram aí. Ela continua viva e operante, se bem que sem a pujança de outrora. Depois do início de um processo de revisão de suas idéias, cujo estopim podemos identificar na realização apenas em parte dos seus prognósticos originais, isso a partir dos últimos anos da década de 1960 e sob o efeito da vaga ditatorial que varreu a América Latina, bem, depois do início de tal processo a Cepal reprocessou seu legado em duas direções diferentes. Absorvendo os reparos feitos por Cardoso e Faletto (1973), uma vertente nova foi gerada, a do "capitalismo tardio", que procurava ver as economias periféricas não mais como mero comportamento adaptativo ao sistema capitalista internacional, mas sim desde seu dinamismo interno próprio (embora tal corrente não se circunscreva a este autor, Mello (1991) a representa bem). A outra vertente é a de um "neo-estruturalismo" mais reformista, isto é, que preconiza uma nova estratégia de inserção na economia internacional, depurada do enfrentamento que o antigo estruturalismo podia sugerir e mais afinada com o emergente discurso da urgência de ajustes macroeconômicos. Para ver críticas acerbas dessas duas vertentes, a primeira interpretada como uma redução da problemática da industrialização capitalista retardatária à pura e simples instalação interna do departamento de bens de produção, com desprezo pela questão nacional e da participação social e democrática, e a segunda, como conformista, que pôs de lado a proposta original da Cepal e se embeveceu com encantamentos neoliberais, consulte Sampaio Jr. (1997: 31-63). Ainda sobre a Cepal hoje, pode-se ver também Rodríguez \& Burgeño \& Hounie \& Pittaluga (1995).
} 
Mais que um inventário exaustivo e minucioso da obra de Celso Furtado - mesmo porque há diversos trabalhos que procuram fazer isso, como os já citados Cepêda (1998), Guimarães (1993 e 1999), Mallorquín (1993 e 1994), Mantega (1995), Moraes (1995), Oliveira (1983 e 1986) e Sampaio Jr. (1997), entre outros —, importa aqui chamar a atenção especificamente para um de seus aspectos, que é o do lugar da Nação neste pensamento e de que maneira a questão da "construção nacional" e a do desenvolvimento (ou do subdesenvolvimento) ligam-se, ou melhor, tornam-se uma só. Na verdade, e é isso que pretendo indicar doravante, em Furtado a noção de subdesenvolvimento significa o impedimento da construção e da integração nacional, ou por outra, a construção da Nação, que é o mote geral e primordial de Furtado, implica necessariamente a superação do subdesenvolvimento: é até possível que o processo histórico-social de constituição de um sistema econômico nacional possa avançar um certo tanto, mas a sua efetivação completa somente é factível se rompidos os grilhões do subdesenvolvimento. Ou seja, em Furtado o subdesenvolvimento é a antítese da Nação e, como ele mesmo frisa em trabalhos mais recentes (basicamente de 1990 para cá, mas mesmo antes disso), há um momento em que se deve escolher entre um e outro. Ora, entendendo-se que desde sempre a Furtado interessa a Nação, poder-se-ia mesmo dizer que o pensamento furtadiano, nesse sentido, torna-se uma teoria da superação do subdesenvolvimento.

Trata-se aqui, portanto, de tentar mostrar o esforço de Furtado em subordinar o processo de acumulação de capital aos desígnios da sociedade nacional e de fazer do desenvolvimento capitalista um processo efetivo de aumento progressivo do bem-estar geral da população - e, correlativamente, mostrar como a distorção desses mecanismos constitui o fenômeno do subdesenvolvimento, que deve ser combatido teórica e praticamente.

O porto donde parte Furtado já é conhecido: além das influências, é sobretudo do pensamento cepalino - que ele ajudou a estruturar, pois integrou a Comissão de 1949 a 1957 - que vêm as grandes balizas para a pretensão de interpretar o Brasil, "interpretar" num sentido estritamente cepalino, isto é, de "conhecer para transformar"; é com tais insumos que Furtado logra alcançar uma empreitada respeitável, tanto é que, como escreve 
Oliveira (1983: 07), "a vasta, abrangente e diversificada obra intelectual de Celso Furtado representa um marco na história e produção das Ciências Sociais à escala mundial". Partindo daí o economista brasileiro persegue incansável e reiteradamente o mesmo objeto, que é a explicação da especificidade do Brasil, isto é, de seu desenvolvimento capitalista sui generis. Numa palavra, é o subdesenvolvimento brasileiro que Furtado perquere, para explicá-lo e dissolvê-lo. "O novo da produção furtadiana, principalmente de sua fase 'cepalina', é essa síntese: rigorosamente, a produção intelectual de Celso Furtado é a produção do conceito de subdesenvolvimento" (Oliveira, 1983: 26).

Não que a noção de subdesenvolvimento deva sua gênese a Furtado — já mencionei que H. Singer e P. Rosenstein-Rodan já a utilizavam —, mas é que ela pode perfeitamente ser tomada como $o$ eixo do pensamento furtadiano, em torno do qual giram todas as suas demais teorizações. Ademais, paralelamente a sua relevância teórica, a noção de subdesenvolvimento em Furtado reveste-se também de significado histórico, pois é como o processo de transformação do Brasil rumo a relações capitalistas industriais é compreendido e traduzido em linguagem teórica.

\footnotetext{
"A centralidade do tema do subdesenvolvimento [em Furtado] tem como fundamento a capacidade de refletir o próprio movimento de constituição do capitalismo no Brasil, todo o profundo revolver das estruturas econômicas em curso e que acabavam por esbarrar nos obstáculos do subdesenvolvimento. Sua relevância teórica expressa a íntima conexão com o processo em curso no país" (Cepêda, 1998: 12).
}

Temos que compreender bem o que Furtado entende por subdesenvolvimento, porquanto só assim será possível saber no que a noção furtadiana difere e avança em relação às demais; e o sinal diferencial está justamente na singularidade que Furtado vê no desenvolvimento capitalista brasileiro. Em Formação econômica do Brasil, de 1959 e um clássico da interpretação de matriz dual-estruturalista (Bielschowsky, 1989; Mallorquín, 1998), Furtado preocupa-se em apontar desde o início a natureza capitalista do empreendimento lusitano que depois formaria o Brasil, do que é sintomático o fato do livro começar com a afirmação de que a "ocupação econômica das terras americanas constitui um episódio da expansão comercial da Europa" (Furtado, 1982: 05). Ora, dizer isso significa dizer que desde logo o processo histórico-social brasileiro é capitalista e que nasce integrado ao sistema capitalista mundial, mas que, mesmo assim, a formação social e 
econômica daqui será marcada pelo subdesenvolvimento. Ou seja, o fato de sermos capitalistas não nega o subdesenvolvimento.

Eis um ponto importante: a Cepal já havia apontado algo nessa direção, mas é Furtado quem lançará mais luz sobre esse ponto. Vale dizer, que o desenvolvimento capitalista da periferia, embora caudatário da dinâmica capitalista mundial, segue processos próprios, distintos aos dos países capitalistas centrais. Daí segue-se que as diferenças entre o subdesenvolvimento e o desenvolvimento não podem ser entendidas numa escala quantitativa que pressupõe que o percurso histórico seja unívoco, no qual o subdesenvolvimento seria um retardo em relação à posição ocupada pelos demais países ou uma etapa preliminar porém necessária no crescendo rumo ao progresso. Tal é, grosso modo, a interpretação que a teoria neoclássica e as chamadas "teorias da modernização" oferecem do subdesenvolvimento. É precisamente o contrário que Furtado afirma.

Se bem que a estrutura produtiva, a formação social e os demais componentes econômicos, sociais e mesmo políticos da vida dos países desenvolvidos possam ser tomados como objetivos a serem alcançados ("De te fabula narratur", mencionara Marx), o certo é que, segundo Furtado, não o serão pelo mesmo caminho nem repetindo as mesmas etapas. Desautorizando as interpretações etapistas à la Rostow (1978), Furtado sustenta que o subdesenvolvimento é o que é porque qualitativamente diverso do processo ocorrido com os países desenvolvidos, quer dizer, possui curso e historicidade próprios. Sendo assim, para Furtado

“O subdesenvolvido é, portanto, um processo histórico autônomo, e não uma etapa pela qual tenham, necessariamente, passado as economias que já alcançaram grau superior de desenvolvimento. Para captar a essência do problema das atuais economias subdesenvolvidas, necessário se torna levar em conta essa peculiaridade" (Furtado, 1971: 181).

Afirmando a especificidade do subdesenvolvimento Furtado está, pois, terçando armas com seus interlocutores liberais. O que Furtado quer expor é justamente a incapacidade das "doutrinas liberais" para perceber e estudar a referida singularidade do subdesenvolvimento, incapazes porque baseadas sobre um universalismo que não se realiza na prática. Para tais doutrinas, haveria um mundo e uma teoria, a sua, suficiente para explicá-lo; além disso, apenas deformações da teoria, casos anômalos renitentes à regra. 
"Esse ponto de vista [o da teoria da modernização], entretanto, apresenta a falha fundamental de ignorar que o desenvolvimento econômico possui uma nítida dimensão histórica. A teoria do desenvolvimento que se limite a reconstituir, em um modelo abstrato — derivado de uma experiência histórica limitada — , as articulações de determinada estrutura, não pode pretender elevado grau de generalidade" (Furtado, 1963: 164; veja também pp. 19-24 e 178).

Não causa espécie, então, que a teoria liberal não capte o subdesenvolvimento e que o estudo que Furtado empreende dele como realidade concreta a ser transformada e como conceito teórico a ser aprimorado traga imperiosamente em seu bojo a crítica à economia política liberal. E já que este ponto foi mencionado, convém concluir dizendo que, para Furtado, essa dupla tarefa — de crítica e de aprimoramento - é tanto mais urgente quanto mais sabemos dos efeitos deletérios que tem para um país o descolamento entre teoria e realidade. Em Formação econômica do Brasil, num capítulo (XXVII) em que Furtado trata da transição para uma economia de trabalho assalariado (fins do século passado, início deste) e, mais especificamente, do problema de nosso desequilíbrio externo, ele se refere às dificuldades do homem público brasileiro ao ter que interpretar a economia brasileira com base em teorias adequadas a realidades longínquas, numa época em que a Ciência Econômica aqui se transformava em "corpo de doutrina" e era aplicada in totum, sem um cotejo com a realidade local: onde esta teimava em opor-se ao mundo ideal da doutrina, aí começava a "patologia social" ${ }^{20}$. Se essa preocupação em combater os equívocos neoclássicos está em Formação, quiçá a obra maior de Furtado ${ }^{21}$, ela faz-se presente noutros trabalhos também (Furtado, 1963; 1964; 1971; 1974, entre outros).

\footnotetext{
${ }^{20}$ Um "padrão" bastante forte na vida pública nacional e também nas esferas intelectuais e acadêmicas, de tal modo que Furtado, ao se referir ao final do século passado e início deste, diz que "Ao historiador das idéias econômicas no Brasil não deixará de surpreender a monótona insistência com que se acoima de aberrativo e anormal tudo o que ocorre no país: a inconversibilidade, os deficits, as emissões de papel-moeda. Essa 'anormalidade' secular não chega, entretanto, a constituir objeto de estudo sistemático. Com efeito, não se faz nenhum esforço sério para compreender tal anormalidade, que em última instância era a realidade dentro da qual se vivia” (Furtado, 1982: 160).

${ }^{21}$ Sobre este livro, Iglésias escreve o seguinte: “(...) Sempre objetivo e exato, [Formação] destaca-se pela técnica de elaboração requintada. É dos poucos volumes da bibliografia nacional que apresentam rigor científico. Nada em suas páginas lembra o polemista ou acadêmico, que se esmera em dissertação brilhante. A obra se afirma pela estrutura sólida, acuidade e concisão. Seu conhecimento é enriquecedor pelas informações que dá e sobretudo interpretações, que recolocam muitos problemas históricos. O estudo vem a ser, em conseqüência, proveitoso e estimulante" (Iglésias, 1971: 208). Ainda a esse respeito, é conveniente lembrar, seguindo Cepêda (1998: 37-87), que Furtado descende de uma linhagem da historiografia brasileira Roberto Simonsen e Caio Prado Jr. — contrária à tese liberal da “vocação agrária brasileira”.
} 
Pois bem, eis o ponto de vista da teoria neoclássica, que Furtado reputa como inválido pois não capta as determinações históricas e sociais de nosso desenvolvimento capitalista e que o transformam em subdesenvolvimento. Nesse sentido, e para dizê-lo novamente, o subdesenvolvimento é entendido como um desenvolvimento capitalista singular, sui generis. Posto e entendido isso, compete nesse momento indicar como produzse esse subdesenvolvimento - ou como o processo de desenvolvimento capitalista torna-se subdesenvolvimento —, uma vez que é nesse expediente que o papel da Nação para Furtado e a relação desta com o subdesenvolvimento surge integralmente.

No esquema interpretativo de Furtado as categorias de progresso técnico, produtividade média do trabalho, sociedade nacional, oferta de mão-de-obra, modernização, padrões de consumo, elites, racionalidade, centros internos de decisão, entre outras, são tramadas para possibilitar, através da perspectiva assim arquitetada, a compreensão dinâmica e histórica do desenvolvimento e do subdesenvolvimento, mas de um tal modo que, no mais das vezes, o exame e a explicitação de um desses dois termos acaba servindo para esclarecer as nuanças do outro. Além disso, ao proceder assim, Furtado lança luz sobre o fato fundamental e importantíssimo de que o subdesenvolvimento é, mais que um processo puramente econômico ou técnico, um processo político, de escolhas políticas feitas no âmbito das sociedades subdesenvolvidas. Vejamos isso.

No centro de tudo está a difusão, ou assimilação, do progresso técnico. Segundo Furtado, a difusão desse progresso técnico seria, nos países desenvolvidos, executada de maneira racional, utilizando e fazendo utilizar os recursos sociais e econômicos disponíveis e correspondendo sempre, ou no mais das vezes, a um determinado grau de acumulação de capital. O uso de uma tal ou qual tecnologia seria feita com ocupação adequada das terras, dos capitais e da mão-de-obra disponível, de modo que tanto as classes mais abastadas quanto os trabalhadores consegueriam usufruir os efeitos positivos gerados pela referida tecnologia. Ou seja, o progresso técnico produz aí bons resultados — bem-estar — porque está sempre em correspondência com a disponibilidade de mão-de-obra e com o nível de acumulação de capital e de excedente econômico daquelas sociedades. Haveria portanto uma relação virtuosa entre a produção, difusão e assimilação do progresso técnico e as condições econômicas e sociais mais gerais da sociedade. Grosso modo, assim seria o desenvolvimento (Furtado, 1963, passim). 
O subdesenvolvimento seria, de acordo com Furtado, a quebra ou ausência da relação virtuosa referida acima. Quer dizer, seria a utilização de progressos técnicos ou então do excedente econômico feita desconsiderando o nível de acumulação de capital e a disponibilidade de outros fatores (mão-de-obra, terras etc.) desta sociedade; noutros termos, tanto o emprego do progresso técnico quanto a adoção de padrões de consumo sofisticados descolados da realidade socioeconômica local, o que no mais das vezes significa tecnologias relativamente avançadas, que são poupadoras de mão-de-obra e de terras, em contraste justamente com a abundância dessa mão-de-obra e dessas terras. Especificamente em relação ao padrão de consumo, essa sua dessintonização com a acumulação local ganhará de Furtado o nome de "modernização", processo que não pode ser confundido com desenvolvimento.

"Chamaremos de modernização a esse processo de adoção de padrões de consumo sofisticados (privados e públicos) sem o correspondente processo de acumulação de capital e progresso técnico nos métodos produtivos" (Furtado, 1974: 81).

Agora visto como processo mais geral, em resumo o subdesenvolvimento distingue-se então por essa não-correspondência entre utilização do progresso técnico, padrões elevados de consumo e condições econômicas e sociais mais gerais da sociedade em questão. Num escrito relativamente recente, Furtado escreve:

“O subdesenvolvimento é um desequilíbrio na assimilação dos avanços tecnológicos produzidos pelo capitalismo industrial a favor das inovações que incidem diretamente sobre o estilo de vida. É que os dois processos de penetração de novas técnicas se apoiam no mesmo vetor que é a acumulação. Nas economias desenvolvidas existe um paralelismo entre a acumulação nas forças produtivas e diretamente nos objetos de consumo. O crescimento de uma requer o avanço da outra. A raiz do subdesenvolvimento reside na desarticulação entre esses dois processos causada pela modernização" (Furtado, 1992d: 08, itálicos meus).

Ora, como a passagem citada acima permite ver, a "desarticulação" aludida por Furtado é significativa porque o uso de progresso técnico (aumentos de produtividade, assimilação de novas técnicas) tem em vista padrões de consumo sofisticados, isto é, restritos. Ao invés do excedente econômico ser aplicado prioritariamente em formas padrões - de consumo que sejam adequadas a toda a sociedade, elevando o nível de bemestar geral, esse excedente é carreado para os bens que as elites consomem — daí o subdesenvolvimento. O ponto diferencial entre desenvolvimento e subdesenvolvimento 
reside pois na maneira pela qual o excedente econômico é apropriado, utilizado e distribuído.

Mas o processo do subdesenvolvimento não se limita a isso apenas, há um ponto de suma importância que deve ser indicado e ressaltado. É preciso entender que a utilização do progresso técnico e do excedente econômico tal qual configurada no subdesenvolvimento não é obra do acaso mas refere-se antes de tudo a escolhas, escolhas sociais e politicas. No caso dos países desenvolvidos, essas escolhas dão prioridade à elevação ou à manutenção de um nível razoável de bem-estar geral, que contemple as necessidades econômicas e sociais básicas da população, enquanto que o mesmo não acontece nos países subdesenvolvidos. Nestes, o excedente é submetido ao consumo das elites e apropriado de modo francamente excludente; ou seja, o subdesenvolvimento é uma opção por uma forma de apropriação do excedente econômico que confere preponderância ao estilo de vida e ao consumo das elites. Esse aspecto é relevante pois indica que para Furtado o processo de desenvolvimento/subdesenvolvimento pode e deve ser regulado politicamente - entender o subdesenvolvimento para Furtado é, portanto, entender o funcionamento e as características dessa regulação (Furtado, 1980). É o próprio Furtado quem diz que

\footnotetext{
"O que caracteriza o desenvolvimento é o projeto social subjacente. O crescimento, tal qual o conhecemos, funda-se na preservação dos privilégios das elites que satisfazem seu afã de modernização. Quando o projeto social dá prioridade à efetiva melhoria das condições de vida da maioria da população, o crescimento se metamorfoseia em desenvolvimento. Ora, essa metamorfose não se dá espontaneamente. Ela é fruto da realização de um projeto, expressão de uma vontade política" (Furtado, 1984: 75, grifos meus).
}

Resta dizer que o padrão de consumo dessas elites está finamente sintonizado com os estilos de vida existentes nos países desenvolvidos. Por isso as tais opções acima referidas significam descompasso entre as condições gerais da sociedade e a utilização do excedente econômico: cria-se uma situação ímpar, em que o consumo das elites é de país capitalista central mas o sistema produtivo é de país periférico. O problema portanto é que as elites se apropriam do excedente econômico não com vistas a garantir o bem-estar geral da população mas para satisfazer padrões de consumo ditados externamente, fora da sociedade nacional; gera-se assim um “desequilíbrio ao nível dos fatores”. É assim que, 
com o estreitamento dos laços de dependência externa, a condição periférica passa a subdesenvolvida ${ }^{22}$.

"O subdesenvolvimento tem suas raízes numa conexão precisa, surgida em certas condições históricas, entre o processo interno de exploração e o processo externo de dependência. Quanto mais intenso o influxo de novos padrões de consumo, mais concentrada terá que ser a renda. Portanto, se aumenta a dependência externa, também terá que aumentar a taxa interna de exploração" (Furtado, 1974: 94).

Sendo assim, o subdesenvolvimento para Furtado é um processo histórico-social que assenta em bases políticas — há aí uma análise política, cuja acuidade discutiremos mais adiante - , a partir das escolhas e das decisões que são tomadas a respeito do destino a ser dado ao excedente econômico - no caso, alimentar gastos que têm como parâmetro e fim as escolhas das elites inspiradas pelo que vem do exterior, não a população em geral ou a sociedade nacional. Por tudo isso é que o subdesenvolvimento é caracterizado por Furtado como um desenvolvimento capitalista específico, qualitativamente diverso do que se dá nos países centrais.

À guisa de resumo do que foi exposto até aqui, podemos perfeitamente tomar o que Sampaio Jr. escreveu:

\begin{abstract}
"Na interpretação de Celso Furtado, o subdesenvolvimento é produto de um sistema econômico mundial que integra, em um mesmo padrão de transformação, formações sociais que têm capacidades assimétricas de introduzir e difundir progresso técnico (...) O subdesenvolvimento surge quando, ignorando tais diferenças [quanto à já referida capacidade dos países de elevar a produtividade média do trabalho e de socializar o excedente social], as elites que monopolizam a apropriação do excedente impõem, como prioridade absoluta do processo de acumulação, a cópia do estilo de vida dos países centrais, impedindo assim a integração de parcela considerável da população no padrão de vida material e cultural propiciado pelo capitalismo” (Sampaio Jr., 1997: 196-197).
\end{abstract}

Os efeitos socioeconômicos desse "desenvolvimento mimético", que é o desenvolvimento capitalista brasileiro, são na exata proporção da dissociação entre as condições sociais gerais da população, a acumulação de capital (o excedente econômico) e a apropriação e utilização, pelas elites nacionais, desse capital em favor de seu modo de vida e consumo; entre todos, todavia o efeito que mais nos interessa aqui é aquele da "heterogeneidade estrutural brasileira", que nada mais é que a idéia de dualismo. Segundo

22 "Para Furtado, a posição periférica só gera subdesenvolvimento nas sociedades em que as decisões intertemporais de gasto se divorciam das necessidades do conjunto da população e da dotação de recursos 
Furtado, pelo processo histórico-social brasileiro, tal qual visto em traços simplificados linhas atrás, configurou-se um quadro em que há um pólo dito "moderno", dinamizado e alimentado pelo excedente gerado nos setores exportadores e que segue de perto o padrão de consumo do centro capitalista - pólo esse em que estão as elites, evidentemente —, e um pólo dito "atrasado", em que vive a maior parte da população brasileira, ligada a atividades de subsistência e com modesto — para não dizer pobre — nível de vida. A economia e a sociedade brasileiras estariam assim cindidas em duas metades praticamente opostas, resultantes de um mesmo processo, o do subdesenvolvimento. Aliás, uma das características do subdesenvolvimento seria justamente a renovação desse dualismo ao longo do tempo. Como o próprio Furtado diz, da expansão capitalista européia teríamos que, na periferia,

\footnotetext{
"Contudo, a resultante foi quase sempre a criação de estruturas híbridas, uma parte das quais tendia a comportar-se como um sistema capitalista, a outra, a manter-se dentro da estrutura preexistente. Esse tipo de economia dualista constitui, especificamente, o fenômeno do subdesenvolvimento contemporâneo" (Furtado, 1963: 180).
}

É de se notar que o dualismo estrutural não é apenas mais um dos efeitos do subdesenvolvimento, antes ocupa lugar central na interpretação furtadiana. Nesse caso, é o subdesenvolvimento que leva ao dualismo, porém a existência e a profundidade do dualismo servem para aquilatar fielmente o grau de subdesenvolvimento de uma sociedade. Donde “(...) o grau de subdesenvolvimento está dado pela importância relativa do departamento atrasado, e a taxa de crescimento é função do aumento da importância relativa do departamento desenvolvido" (Furtado, 1963: 197) ${ }^{23}$.

Noutra passagem Furtado diz, com o jargão próprio do métier economista, que

"podemos definir uma estrutura subdesenvolvida como aquela em que a plena utilização do capital disponível não é condição suficiente para a completa absorção da força de trabalho, ao nível de produtividade correspondente à tecnologia que prevalece no setor dinâmico do sistema. É a heterogeneidade tecnológica entre setores ou departamentos de uma mesma economia que caracteriza o subdesenvolvimento" (Furtado, 1963: 195).

Está visto que o dualismo tem grande importância para Furtado pois nasce das "irracionalidades" próprias do subdesenvolvimento, do uso inadequado, se se tem como 
marco as necessidades gerais da população, que é feito do excedente econômico, do progresso técnico, dos aumentos de produtividade etc. Para dizê-lo novamente, tais elementos recém-citados são todos carreados para a satisfação das elites quando - e nesse ponto Furtado é claro - deveriam servir para abrandar ou dissolver do todo as agruras a que a maioria da sociedade brasileira é submetida. Acrescente-se que se trata de uma explicação do fenômeno do dualismo que, a despeito dos problemas que porta (que veremos mais adiante), escapa das análises simplistas e meramente descritivas, tornando-se por isso uma interpretação respeitável, que vai buscar fundo na estrutura produtiva e econômica da sociedade nacional as chaves explicativas do subdesenvolvimento ${ }^{24}$.

Entendido que até aqui Furtado forneceu um diagnóstico do que vem a ser o subdesenvolvimento, daqui por diante ele envereda pelo caminho da prescrição para a correção desse problema; embora seja um tema igualmente relevante, para os objetivos deste capítulo e desta dissertação é suficiente deixar indicado rapidamente como o economista brasileiro pensa poder quebrar o "círculo vicioso" do subdesenvolvimento. O expediente é conhecido, e segue de perto a proposta do pensamento cepalino. O carro-chefe do processo seria a industrialização, que suplantaria a economia primário-exportadora e daria possibilidade aos países periféricos - Brasil sobretudo - de fugir à sina da deterioração dos termos de troca; entretanto, para que essa industrialização não acabe trilhando o trajeto já demarcado pelo subdesenvolvimento, o que faria que a industrialização apenas renove, conquanto em outro plano, a condição periférica nacional, ela deve ser capitaneada pelo Estado: a ele caberia o papel de, "keynesianamente", direcionar e sustentar o gasto público e a atividade econômica para fins nacionais. Ou seja, para Furtado cabe ao Estado fazer com que o excedente econômico e os avanços técnicos sejam empregados de acordo e em compasso com as condições sociais e econômicas da sociedade - eliminando assim aquele hiato entre o nível da acumulação de capital e o

\footnotetext{
${ }^{23}$ Consulte também Furtado (1964: 81).

24 “Ao indicar o dualismo (...) das economias coloniais, que possibilitam a concretização da dependência, [Furtado] singulariza um dos aspectos da formação social brasileira. Identifica a dependência como inerente à formação subdesenvolvida. Descreve, compreende e explica a história a partir das desigualdades entre as relações internacionais e nacionais. Desse modo, apreende o problema da dependência econômica como um aspecto da questão nacional. (Diríamos que nos resgata do limbo. Nomina-nos: somos dependentes)" (Guimarães, 1993: 34-35).
} 
direcionamento desta acumulação (Furtado, 1963; 1964; 1971) ${ }^{25}$. E tão-somente o Estado poderia assumir tal tarefa porque apenas ele seria capaz de, "weberiana" e "mannheimianamente", através do planejamento, por-se acima dos condicionantes sociais e dos interesses particulares, constituindo-se por isso em ponto de concentração dos “interesses nacionais" — ou do "interesse público".

"Os conflitos entre os indivíduos podem ser resolvidos dentro de um sistema de arbitragem estabelecido em lei, pois sempre existe um interesse público que paira sobre os indivíduos e o árbitro aceito do interesse público é o Estado" (Furtado, 1964: 68, ênfase minha). ${ }^{26}$

Entendido como o processo de subdesenvolvimento se desenrola segundo a ótica de Celso Furtado, é preciso agora chamar a atenção para alguns pontos cujo núcleo é um só: a formação da Nação e a defesa da sociedade nacional, eventos que presumem a superação do subdesenvolvimento. Noutros termos e explicando melhor, convém indicar que, no esquema interpretativo de Furtado, a defesa e a consolidação da sociedade nacional somente podem ser feitas com a resolução do subdesenvolvimento, quer dizer, subdesenvolvimento e sociedade nacional são termos antitéticos.

\footnotetext{
${ }^{25}$ A filiação keynesiana de Furtado é notória e não espanta a ninguém (Cepêda, 1998; Guimarães, 1999; Mantega, 1989: 30). Mas é interessante notar que, ao delegar ao Estado a tarefa de sustentar a atividade econômica, Furtado não está lhe pedindo nada inédito, pelo contrário. Em Formação vemos que se a economia brasileira de fins do século XIX e início do seguinte havia conseguido desenvolver mecanismos pelos quais a "classe dirigente cafeeira" lograva transferir para toda a sociedade o peso de seus prejuízos cíclicos — a conhecida "socialização das perdas" (Furtado, 1982: 165-166) —, ela conseguiu também pôr o Estado a serviço de uma política de valorização do café que consistia na compra de estoques do produto a serem queimados ou de alguma maneira destruídos, com o que se mantinha o nível do preço do café e os lucros dos cafeicultores. A despeito do interesse imediato da economia cafeeira, tal procedimento (que foi até 1930, mais ou menos) representou - e isso é que importa ressaltar - um programa de fomento da renda nacional, uma política econômica anticíclica tão grande quanto a de países industrializados de então; um keynesianismo antes de Keynes: "Estávamos, em verdade, construindo as famosas pirâmides que anos depois preconizaria Keynes" (Furtado, 1982: 192). A importância de tal política é duplamente significativa, tanto porque "(...) a recuperação da economia brasileira, que se manifesta a partir de 1933, não se deve a nenhum fator externo e sim à política de fomento seguida inconscientemente no país e que era um subproduto da defesa dos interesses cafeeiros" (Furtado, 1982: 193), quanto porque, atendendo imediatamente às solicitações dos cafeicultores, o Estado brasileiro estava na verdade fortificando, a longo prazo e sem o saber, os interesses da burguesia industrial brasileira. Enfim, políticas keynesianas avant la lettre.

${ }^{26}$ Essa maneira de interpretar o papel do Estado, do planejamento e dos intelectuais no processo de desenvolvimento/subdesenvolvimento econômico informou grandemente a vida pública de Furtado e sua atuação no BNDE, SUDENE, Ministério do Planejamento etc. De tudo isso fica a permanente preocupação furtadiana de união da teoria com a prática; esclarecedoramente, ele diz que "É indispensável não esquecer
} 


\section{Subdesenvolvimento versus Nação}

Vimos que para Furtado o subdesenvolvimento vem a ser um processo em que as condições nacionais - econômicas, sociais e políticas — são desconsideradas em nome de ditames vindos do exterior, externos à sociedade nacional. $\mathrm{O}$ resultado é que o padrão do desenvolvimento capitalista brasileiro não segue o grau de acumulação nacional nem do excedente econômico aqui produzido, operando um descolamento entre um lado e outro quando o desenvolvimento marca-se justamente pela ocorrência dessa sintonia. Ou seja, segundo Furtado, há uma "irracionalidade" ou uma "racionalidade sui generis" que faz com que, no subdesenvolvimento, o sistema produtivo venha a reboque do padrão de consumo mimético das elites nacionais, quando o desejável seria o contrário. Como ele mesmo escreve, aqui "Não é a evolução do sistema produtivo que conforma o processo de transformação do sistema de produção; (...) as novas atividades orientam-se pela demanda final, como um edifício que se constrói de cima para baixo" (Furtado, 1980: 124 e 127) ${ }^{27}$.

Ora, o leit-motiv de Furtado é precisamente denunciar essa "irracionalidade" e combatê-la, tanto mais porque ela é impeditiva da sociedade nacional. É impeditiva porque trata-se de uma lógica que exclui grande parte da população da determinação dos caminhos do desenvolvimento capitalista aqui em marcha: são o padrão e os valores das elites locais, largamente influenciados pelo que ocorre nos centros capitalistas, que decidem e optam por essa via de industrialização e modernização. Nesse aspecto, e entendido que nosso modo de participar do sistema capitalista internacional está na dependência de decisões políticas internas, conforme vimos, esse desenvolvimento capitalista contempla apenas uma parte muito diminuta da sociedade e não toda a sociedade nacional. Dizendo mais objetivamente, a definição do desenvolvimento capitalista não parte nem tem em conta uma sociedade nacional.

que uma teoria só se justifica quando nos arma para conhecer a realidade e atuar sobre ela"; "E o objetivo da ciência é produzir guias para a ação prática" (Furtado, 1963: 108-109; 1964: 23, nessa ordem).

${ }^{27}$ Veja Sampaio Jr. (1997: 207). 
Daí que, segundo Furtado, a passagem de um processo de subdesenvolvimento para um de desenvolvimento somente pode ser feita, porque a requer, com a constituição e a consolidação de uma efetiva sociedade nacional, quer dizer, tal passagem só se dará se as decisões acerca dos rumos do desenvolvimento capitalista brasileiro forem postas sob o crivo da sociedade nacional - e não de apenas um ou outro segmento dela, que repassam critérios recebidos do exterior ${ }^{28}$. Só assim o processo histórico-social brasileiro irá contemplar as condições e as necessidades mais gerais da população nacional. Do mesmo modo, para Furtado a Nação só poderá ser constituída e fortalecida de fato se o "circulo vicioso" do subdesenvolvimento for rompido, justamente porque — para repeti-lo mais uma vez - um termo impede o outro.

Além do mais, esse reordenamento do processo histórico-social brasileiro, de desmontagem das amarras do subdesenvolvimento e de consolidação da Nação, não pode ser pensado e executado sem a própria revisão da posição brasileira no bojo do sistema centro-periferia, vale dizer, do sistema capitalista internacional. Isso porque a permanência dessa estrutura implica na realimentação dos laços de dependência externa que sustentam o subdesenvolvimento (pois é daí que as elites retiram o modelo para seu padrão de consumo).

Nesse sentido - e é isso o que mais interessa ressaltar neste capítulo da dissertação —, a teoria do desenvolvimento/subdesenvolvimento de Furtado converte-se numa teoria de superação do e ruptura com o sistema centro-periferia. Não que Furtado pretendesse pôr abaixo todo o sistema capitalista internacional - e não se cobre isso dele, pois em momento algum esse foi o objetivo do economista brasileiro; mas o fato é que, no pensamento furtadiano, a superação do subdesenvolvimento somente se fará se, internamente, uma sociedade nacional lograr alcançar consistência suficiente para submeter a seus desígnios a acumulação capitalista, e se, externamente, a inserção brasileira no sistema centro-periferia for questionada, interrompendo-se os fluxos da dependência externa. Apenas para que fique mais claro o exposto, e já avançando o que é objeto do próximo capítulo, vista desta perspectiva a interpretação que Furtado oferece do desenvolvimento capitalista brasileiro contrasta bastante com a "teoria da dependência" de

\footnotetext{
${ }^{28}$ (...) o esforço de Furtado consiste em estabelecer critérios éticos para o funcionamento da economia, único meio de subordinar a lógica individualista da iniciativa privada aos interesses coletivos da sociedade nacional” (Sampaio Jr., 1997: 198).
} 
Fernando Henrique Cardoso, posto que, nesta chave, a interpretação de Cardoso traz embutida a acomodação subordinada da sociedade nacional no sistema centro-periferia: enquanto para Furtado o desenvolvimento implica necessariamente no questionamento dessa posição, em Cardoso o desenvolvimento pode se fazer apesar dessa posição periférica e dependente.

Deixando por ora tais contrastes de lado, o que importa frisar é que, assim visto, o esquema de Furtado alinha-se com o de outros autores, sobretudo Caio Prado Jr. e Florestan Fernandes, pois trata da necessidade de garantir a persistência e a manutenção de processos históricos responsáveis pela consolidação dos fundamentos mais gerais (econômicos, sociais, culturais etc.) da sociedade e do Estado nacionais (Sampaio Jr., 1999: 415). Também como os autores citados, o espaço nacional adquire importância fundamental para Furtado, não como mero território, mas antes como proteção contra as injunções do sistema capitalista internacional e meio de submissão da lógica capitalista aos ditames nacionais ${ }^{29}$. Sendo assim, fica evidente a centralidade que Furtado delega à Nação, à sociedade e à economia nacionais, e como o subdesenvolvimento marca-se justamente pela oposição em que se coloca em relação a esse processo de formação nacional - vale dizer, que contempla toda a sociedade do país. Portanto, a defesa que Furtado faz da sociedade nacional somente é possível, de acordo com seu esquema analítico, com a superação do subdesenvolvimento e dos laços de dependência externa que ele traz consigo, ou, por outra, a superação do subdesenvolvimento (e da dependência externa) só é possível para Furtado se as rédeas do processo econômico e social brasileiro forem postas sob o controle dos "centros internos de decisão", vale dizer, sob os auspícios da sociedade nacional (Furtado, 1980: passim).

Pelo exposto, fica razoavelmente patente como Furtado logrou produzir, a partir de suas influências várias e com o pensamento cepalino como norte, uma teorização acerca do binômio desenvolvimento/subdesenvolvimento bastante fecunda, que foge à "camisa de força" das explicações neoclássicas recorrentes. Primeiro, porque demonstra que o subdesenvolvimento brasileiro é um desenvolvimento capitalista específico,

\footnotetext{
${ }^{29}$ Sobre esse espaço, Sampaio Jr. (1999: 417) escreve: "Pensado como um centro de poder que condensa a vontade política da coletividade, a forma nacional é aqui — única e exclusivamente — um meio das sociedades que vivem sobredeterminadas pelo campo de força do sistema capitalista mundial controlarem o seu tempo histórico".
} 
qualitativamente diverso, e não apenas um estágio retardado de um único e inequívoco processo econômico; segundo, porque lança luz sobre os aspectos políticos do subdesenvolvimento sobejamente desconsiderados, uma vez que indica com exatidão como esse desenvolvimento capitalista singular é fruto de escolhas e decisões políticas tomadas por elites nacionais acerca do destino a ser dado à acumulação de capital. Esse último ponto deve ser posto em destaque: ele mostra que Furtado tem sim uma análise política do desenvolvimento capitalista, com o que se pode aplacar possíveis censuras de economicismo em Furtado. O que, contudo, não impede que se diga que, apesar de existente e muito valiosa, a análise política de Furtado tem problemas, conforme veremos a seguir. Examinar criticamente a análise política furtadiana não significa dizer que ela inexista, o que seria uma impropriedade, mas sim reconhecê-la em toda a sua envergadura.

Seja como for, a idéia nuclear desse capítulo já foi exposta, compete apenas reforçála: a interpretação que Furtado dá ao desenvolvimento capitalista brasileiro pode ser lida como uma teoria da necessária e urgente superação do subdesenvolvimento, necessária e urgente por conta tanto da relação contraditória entre esse modelo de desenvolvimento e a consolidação da sociedade nacional quanto da posição dependente e subordinada desta no sistema capitalista internacional. Ou seja, segundo Furtado, se é o desenvolvimento capitalista nacional que se quer, há que se questionar tenazmente essa posição, da qual decorre o subdesenvolvimento. Assim, o processo de desenvolvimento capitalista efetivo implica a um só tempo a consolidação da Nação e a superação do subdesenvolvimento e da dependência externa. Como será visto nos capítulos seguintes, os estudos sobre a dependência de Cardoso levam a interpretação do desenvolvimento capitalista brasileiro para um outra direção e perdem a radicalidade da visão furtadiana ao sustentar a idéia de que o desenvolvimento capitalista pode ser logrado mesmo com uma acomodação subordinada da sociedade nacional ao sistema capitalista nacional.

Resta agora verificar alguns limites do pensamento furtadiano ${ }^{30}$.

\footnotetext{
${ }^{30} \mathrm{O}$ que foi apresentado até aqui é quanto nos basta para a proposta deste capítulo da dissertação. Considerações mais aprofundadas sobre esses ou outros aspectos da obra de Furtado o leitor pode buscar em Mallorquín (1993).
} 


\section{Problemas e impasses na defesa da Nação}

No que foi apresentado até aqui creio haver tornado razoavelmente patente o núcleo central deste capítulo da dissertação: a defesa que Celso Furtado faz da Nação — sociedade nacional, economia nacional, Estado nacional, espaço nacional - e como ele aponta claramente que a consolidação nacional não se coaduna com o subdesenvolvimento, antes requer sua superação. Contudo, na execução dessa tarefa (que é tanto teórica quanto prática) Furtado esbarra nalguns problemas que merecem atenção. Refiro-me basicamente a dois, na verdade interligados; são eles o entendimento do processo capitalista que as análises furtadianas sobre o desenvolvimento capitalista brasileiro denotam e a questão da heterogeneidade estrutural brasileira — nosso "dualismo". Esmiuçar tais pontos não deixa de ser uma maneira de aquilatar melhor o dual-estruturalismo de Celso Furtado.

Ao primeiro ponto. Bem observado, há no pensamento de Furtado — bem como no da Cepal - uma interpretação nebulosa do caráter antagônico do capitalismo; não que esse antagonismo seja negado de roldão, mas é que por vezes ele parece não ser adequadamente considerado. Evidentemente há oposição e divergência de interesses entre as elites e as classes populares no subdesenvolvimento segundo Furtado, porém o que se percebe é que no desenvolvimento a ser trazido pela industrialização esses conflitos teriam sua amplitude diminuída. Ou seja, Furtado supunha que a industrialização acarretaria superação do subdesenvolvimento, o que significaria redução dos antagonismos de classe, quando é o próprio processo de industrialização, de passagem de uma economia mercantil para uma de base industrial, que põe em ação ou acirra as disputas entre classes sociais. Nesse caso, seguindo Rodríguez (1981), pode-se dizer que, ao enfatizar a estrutura produtiva periférica, o dual-estruturalismo furtadiano - tal qual a Cepal - não deu um tratamento mais acurado das relações sociais postas em movimento pela industrialização brasileira. Referindo-se ao pensamento cepalino, mas de um modo que pode ser estendido a Furtado, Rodríguez sustenta que:

"Em síntese, a limitação que se deseja destacar deriva de que as contribuições teóricas da Cepal (que, essencialmente, dizem respeito ao modo como se vai transformando a estrutura de produção de bens 
e serviços durante a industrialização periférica) não consideram, nem analisam, as relações sociais que estão na base do processo de industrialização e das mudanças de estrutura que ele traz consigo" (Rodríguez, 1981: 254) ${ }^{31}$.

Nesse ponto fica evidente a semelhança de Furtado com G. Myrdal, para quem as camadas mais pobres da população européia, ao pressionarem as camadas mais ricas e ao conquistarem o apoio dos Estados nacionais, tiveram seu nível de bem-estar aumentado e viram-se integradas nos nascentes Welfare States (Myrdal, 1960: 61-64). Ou seja, os antagonismos de classes levam ao desenvolvimento capitalista, que por sua vez leva ao apaziguamento desses antagonismos (Mantega, 1995: 57-63). O esquema teórico de Furtado segue caminho semelhante: se no subdesenvolvimento a abundância de mão de obra favoreceria o capitalista (que reteria maior parte do excedente econômico) ${ }^{32}$, gradativamente a classe trabalhadora pressionaria o capitalista, que teria que redistribuir seus dividendos e, para fazer frente a esta pressão, absorver mais progresso técnico, tornando toda a economia mais produtiva, com maiores salários e maior renda e, consequentemente, com maior mercado consumidor interno, invertendo-se a correlação de forças no jogo político (Furtado, 1964: 67). Nesse sentido, temos um processo social em que, através da "dialética do desenvolvimento", os conflitos de classe levam, ao fim e ao cabo, ao bem comum, à satisfação tanto dos capitalistas quanto dos trabalhadores e ao desenvolvimento econômico, político e social da Nação (Santos*, 1998: 61-62).

Interpretando a lógica capitalista dessa maneira, Furtado não poderia deixar de colher complicações mais adiante, sobretudo quanto a uma associação tácita que há em seu pensamento entre industrialização, desenvolvimento econômico, progresso geral da população e democracia ${ }^{33}$ e quanto ao papel político das classes sociais emergentes nesse

\footnotetext{
${ }^{31}$ Numa nota Rodríguez complementa: "De uma outra ótica, pode-se dizer que as contribuições teóricas da Cepal examinam diversos aspectos do desenvolvimento das forças produtivas das economias chamadas subdesenvolvidas, mas não cobrem as relações sociais de produção. Mais exatamente,(...) só são feitas referências laterais — não integradas às contribuições mencionadas - a muito poucas das relações econômicas que formam parte das relações de produção (...)" (Rodríguez, 1981: 254, nota n. 32)

${ }^{32}$ Mantega (1995: 91): "A luta de classes manifesta-se de forma efetivamente antagônica para Furtado apenas no capitalismo primitivo ou então no capitalismo subdesenvolvido, quando o excesso de mão-de-obra condenaria os trabalhadores ao mero salário de subsistência, ficando os aumentos de produtividade nas mãos dos capitalistas"; aqui sim teríamos conflitos políticos e choques sociais.

${ }^{33}$ Essa associação tácita a que me refiro é bem um traço existente já antes em Prebisch, e que Furtado de alguma maneira parece ter herdado. A respeito desse ponto em Prebisch, Gurrieri diz que "Ao definir sua idéia de desenvolvimento de maneira mais específica, [Prebisch] recorre à visão dos economistas clássicos: o progresso técnico consiste em um processo de elevação dos níveis de produtividade real da força de trabalho
} 
processo. Esse modo furtadiano de análise da política e seu reflexo sobre o desenvolvimento capitalista brasileiro ficou evidente no prognóstico a respeito dos efeitos do Golpe de 1964. Em texto de 1967, Furtado mostrou crer que, uma vez rompida a ordem democrática brasileira, devido ao temor que as classes dirigentes brasileiras nutriam do poder político que as classes populares e as camadas urbanas iam granjeando, o próprio desenvolvimento industrial brasileiro estaria em xeque e, mais, entraria em regressão; ou seja, sem democracia não haveria desenvolvimento. Isso porque, ainda segundo o economista brasileiro, as camadas médias e urbanas apareciam para as classes dominantes como as "responsáveis" pela instabilidade política do país, de modo que o caminho conseqüente para a manutenção do status quo conservador seria o do "desenvolvimento pastoril" ou da "pastorização" (Furtado, 1979: 16 e ss.), como que uma revanche dos setores arcaicos contra o dinamismo modernizador da industrialização, cujo resultado seria recessão e estagnação. Sendo assim, a perspectiva otimista de Furtado acerca das possibilidades do desenvolvimento capitalista brasileiro (Kay, 1991: 38) sofre uma certa inflexão e adota ares mais "pessimistas" de Furtado, do que Subdesenvolvimento $e$ estagnação na América Latina, de 1968, e O mito do desenvolvimento econômico, de 1974, são os exemplos precípuos ${ }^{34}$.

obtido como consequiência da adoção de métodos produtivos mais eficientes; os frutos principais desse progresso são a elevação do nível de renda e das condições de vida da população" (Gurrieri, 1982: 15).

${ }^{34} \mathrm{Em} O$ mito do desenvolvimento econômico Furtado deixa patente que seu otimismo dos tempos áureos do dual-estruturalismo (1950-1964) vai cedendo lugar ao pessimismo quanto às perspectivas de desenvolvimento brasileiro. O desencanto de Furtado é evidente quando, depois de questionar projeções de desenvolvimento, em especial as do relatório Limits to growth, de 1972, diz que "A conclusão geral que surge dessas considerações é que a hipótese de generalização, no conjunto do sistema capitalista, das formas de consumo que prevalecem atualmente nos países cêntricos, não tem cabimento dentro das possibilidades evolutivas aparentes desse sistema. E é essa a razão fundamental pela qual uma ruptura cataclísmica, num horizonte previsível, carece de fundamento. O interesse principal do modelo que leva a essa ruptura cataclísmica está em que ele proporciona uma demonstração cabal de que o estilo de vida criado pelo capitalismo industrial sempre será o privilégio de uma minoria. O custo, em termos de depredação do mundo físico, desse estilo de vida, é de tal forma elevado que toda tentativa de generalizá-lo levaria inexoravelmente ao colapso de toda uma civilização, pondo em risco as possibilidades de sobrevivência da espécie humana. Temos assim a prova definitiva de que o desenvolvimento econômico - a idéia de que os povos pobres podem algum dia desfrutar das formas de vida dos atuais povos ricos — é simplesmente irrealizável. Sabemos agora de forma irrefutável que as economias da periferia nunca serão desenvolvidas, no sentido de similares às economias que formam o atual centro do sistema capitalista. Mas, como negar que essa idéia tem sido de grande utilidade para mobilizar os povos da periferia e levá-los a aceitar enormes sacrifícios, para legitimar a destruição de formas de culturas arcaicas, para explicar e fazer compreender a necessidade de destruir o meio físico, para justificar formas de dependência que reforçam o caráter predatório do sistema produtivo? Cabe, portanto, afirmar que a idéia de desenvolvimento econômico é um simples mito" (Furtado, 1974: 75). Desta feita o economista brasileiro dá indícios dos novos rumos que seu pensamento vai tomando e adianta, mutatis mutandis, o "desenvolvimento do subdesenvolvimento" de André Gunder Frank e a "ilusão do desenvolvimento" de 
Ora, o que vemos nessa passagem é que Furtado, apesar de seu esforço em compreender as vicissitudes do desenvolvimento brasileiro no bojo da expansão capitalista internacional, não pôde compreender que o processo culminado em 1964 era justamente o acirramento desta expansão capitalista no Brasil e não seu embotamento, no qual a burguesia nacional estava se decidindo definitivamente por uma posição subordinada, a reboque do capital internacional e contra as camadas populares. Rigorosamente, a negação de qualquer ideal de desenvolvimento nacional autônomo.

"Furtado não se dava conta de que a passagem para uma etapa superior no processo de acumulação dependente requeria uma reconcentração de capital, para o que a ditadura era mais funcional do que a democracia, onde as pressões redistributivas caminhavam na direção oposta” (Sader, 1997: 99$)^{35}$.

Tudo isso vem a propósito de indicar o dito mais acima, que Furtado possui uma visão do capitalismo que lhe acarreta alguns problemas - como os mencionados. Além disso, nesse aspecto de como o pensamento furtadiano encara as relações capitalistas de produção e as relações entre as classes sociais, há ainda a espinhosa questão das relações entre as idéias furtadianas e os interesses da burguesia industrial. De fato, conforme diz Rodríguez em relação ao pensamento da Cepal, essa teorização industrialista acaba por constituir um projeto que dá lugar destacado à burguesia industrial nacional.

"Como se pode observar, a referida proposta [industrialista], de uma forma implícita, supõe a existência de certos grupos sociais e, em linhas gerais, dá prioridade aos interesses de alguns dentre eles. Mesmo quando não afirma que sejam excludentes, destaca e privilegia os interesses industriais

Giovanni Arrighi. Retrospectivamente, em entrevista aqui já citada, Furtado afirma o seguinte sobre sua mudança de perspectiva: "Quando cheguei a este país [Brasil] dez anos depois [do Golpe de 1964], ele já era outro. Outra mentalidade, outra gente, e então perdi a idéia de minha geração de que poderíamos avançar realmente no sentido de concretizar uma sociedade diferente, mais igualitária, mais equânime, menos injusta. Todos esses idealismos que nós, da esquerda, havíamos alimentado tinham desaparecido; haviam sido inviabilizados, todos esses objetivos, o projeto total. Isso teve uma forte repercussão na minha forma de pensar. Daí que todos os meus livros, a partir do Análise do 'modelo' brasileiro [1972], são livros que transmitem uma imagem pessimista do Brasil. E isso porque eu tinha sido um homem otimista. Na Formação econômica do Brasil, aparecia um país que avançava e que tinha um projeto" (Furtado, 1995: 103).

${ }^{35}$ Em favor de Furtado deve-se dizer que a tese da "pastorização" do Brasil foi algo episódico, que não grassou em suas teorizações posteriores; acrescente-se ainda que a cortina de fumaça que envolveu o significado político de 1964 não nublou somente a visão de Furtado, mas de grande parte da intelectualidade brasileira (Mantega, 1995: 100-101). O certo é que Furtado recalibra sua perspectiva mas mantém o pessimismo, agora procurando compreender a passagem do Estado de "mocinho" a "bandido" e a ocorrência de um desenvolvimento econômico que dispensa a democracia e não se faz em benefício da maioria da população brasileira, movimentação intelectual que o levará à teorização da "industrialização do subdesenvolvimento" e que encontrará saída conceitual na idéia já mencionada de "modernização" (Cepêda, 1998: 22-25). 
nacionais em relação aos de outros grupos capitalistas. Entre estes últimos, podem ser assinalados os interesses vinculados à grande propriedade agrária, ao comércio de exportação e importação oriundo do esquema tradicional da divisão internacional do trabalho e ao capital estrangeiro (tanto o comercial como o dedicado à produção primária ou à indústria externa)" (Rodríguez, 1981: 259) ${ }^{36}$.

É bem verdade que, na defesa da sociedade nacional, Furtado acaba permitindo que os "interesses nacionais" sejam lidos de maneira enviesada, como se fossem o travestimento puro e simples de interesses burgueses. Todavia, parece-me que isso não nos autoriza a ver o economista brasileiro como títere da burguesia industrial, o que seria um exagero. $\mathrm{O}$ que parece haver ocorrido é uma afinidade alimentada pelo momento histórico em que Furtado teoriza: Furtado analisa não somente um processo histórico-social passado, antes ele tem diante de sua lente um processo presente de um país que está se constituindo capitalisticamente. Nesse sentido, creio que Oliveira tem mais razão quando afirma o seguinte:

\footnotetext{
"O dual-estruturalismo não é, de nenhum modo, uma teorização vulgar. Sua força residiu, sobretudo, no apontar a emergência de processos que não eram perceptíveis nem importantes para as outras vertentes teóricas. A dualidade 'atrasado-moderno' escapa, por exemplo, tanto à a-historicidade do método neoclássico quanto ao mecanismo das 'etapas' e dos modos de produção sequienciais próprios do stalinismo convertido em oráculo do marxismo. Mas, ele também - inclusive porque teoriza contemporaneamente aos processos que percebe - mascara os novos interesses de classe que se põem como 'interesses da Nação'”' (Oliveira, 1983: 10) ${ }^{37}$.
}

Naturalmente que esse assunto poderia ser mais explorado, porém menciono-o rapidamente para apenas apontar como a já citada visão do capitalismo que Furtado sustenta leva-o a impasses como esses - o que, volto a dizer, não nos autoriza a chamá-lo de "intelectual orgânico" da burguesia ou algo do gênero. Tais problemas e impasses não descaracterizam a defesa que Furtado faz da Nação, antes demonstram como sua defesa foi tão tenaz que fez com que ele não se desse conta desses percalços. Resta agora explorar um pouco o segundo desses percalços, a heterogeneidade estrutural brasileira, entendida por Furtado como um mecanismo fundamental no processo de subdesenvolvimento.

Como vimos, a heterogeneidade estrutural brasileira — o dualismo — é peça central no processo de subdesenvolvimento segundo Furtado. É claro que interpretações dualistas as há de vários matizes e quilates, desde as mais rudimentares, como aquelas de paroxismo

\footnotetext{
${ }^{36}$ Veja também Rodríguez (1988: 88).

${ }^{37}$ Veja também Oliveira (1986: 160).
} 
reducionista de J. Lambert e seus “dois Brasis”, até as com estatuto teórico respeitável. As de Celso Furtado são deste último tipo. Mas é preciso que se entenda: identificando no dualismo um dos problemas de Furtado, não se deseja negar o dualismo na economia e na sociedade brasileira, a existência de setores e regiões em sintonia com o que há de mais avançado no sistema capitalista internacional ao lado de regiões e setores que representam exatamente o oposto do que está na ponta do capitalismo, visto que tal fenômeno está à vista de quem quiser vê-lo. O nervo da questão está no modo como esse dualismo é operado teoricamente.

A arquitetura do dualismo já é conhecida, não precisamos repeti-la mais uma vez. Convém apenas frisar que o processo virtuoso de desenvolvimento deve dissolver os pares de opostos engendrados pelo subdesenvolvimento: "atrasado/moderno", "arcaico/novo", "agricultura/indústria", etc. Ora, é justamente no entendimento que fornece desses dualismos que o pensamento furtadiano falha, reiterando assim o que já assinalei, vale dizer, certa incompreensão da dinâmica do capitalismo. Nesta lente, vendo o desenvolvimento capitalista na periferia como estático, quer dizer, como ocupando só os pólos "modernos" e desprezando os demais, capta-se apenas as expressões superficiais e estanques do processo de expansão do capital e de sua acumulação como se os vínculos vitais entre os pólos pudessem ser desconsiderados e o dualismo fosse quase que uma ausência de capitalismo.

Mais uma vez, portanto, é no problema da percepção das tensões e dos impasses do processo histórico que esbarra a interpretação dual-estruturalista furtadiana. Sobre o dualismo R. Stavenhagen já alertara que

\footnotetext{
“Tais discrepâncias, contudo, não justificam o emprego do conceito de 'sociedade dual', por duas razões principalmente: primeiro, porque os dois pólos são o resultado de um único processo histórico, e, segundo, porque as relações mútuas que mantêm entre si as regiões e os grupos 'arcaicos' ou 'feudais' e os 'modernos' ou 'capitalistas' representam o funcionamento de uma única sociedade global da qual ambos os pólos são parte integrante” (Stavenhagen, 1974: 117).
}

Rigorosamente, essa "única sociedade global” a que se refere Stavenhagen é a sociedade capitalista periférica, a do subdesenvolvimento, que engendra e utiliza essas dualidades em seu processo de acumulação e tece uma rede de relações que exibe o que tais 
pólos são de fato, vale dizer, produtos, resultados e aspectos diferentes porém necessários de uma lógica mais ampla, a do sistema capitalista internacional.

“O importante não é a existência de duas 'sociedades', a saber, de dois pólos que contrastam entre si em termos de diversos índices sócio-econômicos, mas das relações que existem entre estes dois 'mundos'” (Stavenhagen, 1974: 120, grifos meus).

Está visto que o pensamento furtadiano, de corte dual-estruturalista, não é uma teorização menor; pelo contrário, ele esclarece em muito o estatuto periférico brasileiro e procura explicá-lo em seus próprios termos. Refuta as explicações de cunho puramente neoclássico, bem como relativiza as marxistas (Santos*, 1998: 08) ${ }^{38}$. Entretanto, não se deu conta de que há articulações entre os pólos ditos modernos e atrasados, pólos que efetivamente são opostos mas não contraditórios, ou seja, estes não impedem o desenvolvimento daqueles mas os sustentam em interações historicamente construídas.

As palavras de Oliveira referem-se precisamente a isso:

\begin{abstract}
“(...) a ruptura com o que se poderia chamar o conceito do 'modo de produção subdesenvolvido' ou é completa ou apenas se lhe acrescentarão detalhes. No plano teórico, o conceito do subdesenvolvimento como formação histórico-econômica singular, constituída polarmente em torno da oposição formal de um setor 'atrasado' e um setor 'moderno', não se sustenta como singularidade: esse tipo de dualidade é encontrável não apenas em quase todos os sistemas, como em quase todos os períodos. Por um lado, a oposição na maioria dos casos é tão somente formal: de fato, o processo real mostra uma simbiose e uma organicidade, uma unidade de contrários, em que o chamado 'moderno' cresce e se alimenta da existência do 'atrasado', se se quer manter a terminologia (...). O 'subdesenvolvimento' pareceria a forma própria de ser das economias pré-industriais penetradas pelo capitalismo, em 'trânsito', portanto, para formas mais avançadas e sedimentadas deste; sem embargo, uma tal postulação esquece que o 'subdesenvolvimento' é uma produção da expansão do capitalismo (...); na grande maioria dos casos, as economias pré-industriais da América Latina foram criadas pela expansão do capitalismo mundial, como uma reserva de acumulação primitiva do sistema global; em resumo, o 'subdesenvolvimento' é uma formação capitalista e não simplesmente histórica (...)” (Oliveira, 1976: 09, os grifos são meus).
\end{abstract}

O esquema teórico de Furtado, portanto, não atina integralmente com traquejo do capitalismo na periferia e assim não pode dar dimensão maior à originalidade de seu

\footnotetext{
38 "A tese cepalino-furtadiana da dualidade distingue-se da constatação geral e histórica do 'desenvolvimento desigual e combinado’ da tradição marxista (Lênin e Trotski) precisamente porque para Furtado e a Cepal o desenvolvimento é desigual — tanto pelas diferenças qualitativas entre setores que se desconhecem entre si - mas não é combinado. Os dois setores não tem relações articuladas: o setor 'atrasado' é apenas um obstáculo ao crescimento do setor 'moderno', principalmente porque, por um lado, não cria mercado interno e, por outro, não atende aos requisitos da demanda de alimentos” (Oliveira, 1983: 08-09).
} 
produto, a noção de subdesenvolvimento. Em Furtado à oposição entre os pólos não se segue nenhuma conexão e desta, nenhuma síntese, que se processada decerto incrementaria ainda mais o conceito supracitado. A Furtado passa despercebido que, "por detrás dessa aparente dualidade, existe uma integração dialética" (Oliveira, 1976: 19), donde vê-se a dificuldade de entendimento da acumulação capitalista de que sofre dolorosamente, da incompreensão das “entranhas subdesenvolvidas” do capitalismo, que é una mas expressase como dual, forma de operação que muito lhe convém ${ }^{39}$.

“(...) é aqui, paradoxalmente, onde o dual-estruturalismo se aproxima de posições neoclássicas — não há propriamente uma teoria da acumulação na construção teórica do 'subdesenvolvimento', há apenas uma teoria da formação do capital, e esta é a grande responsável pela incapacidade de entender as articulações reais entre os dois setores e a forma dialética dessa coexistência" (Oliveira, 1983: 12).

Os problemas apontados acima são consideráveis, não se trata de negá-los. Porém, é preciso ver que eles não põem a perder a defesa que Furtado faz da Nação. No caso do dualismo, por exemplo, é certo que se Furtado tivesse compreendido melhor as relações dialéticas entre os pólos da economia e da sociedade brasileiras a sua percepção da sociedade nacional teria sido mais completa e, quiçá, o teria livrado de alguns enganos. Todavia, digo novamente, tais percalços não interferem fatalmente naquilo que procurei indicar aqui, que em Furtado subdesenvolvimento e consolidação da Nação são elementos antitéticos, por isso inconciliáveis e, também por isso, a defesa da sociedade nacional faz com que a teoria furtadiana transforme-se numa percuciente teoria da superação necessária e urgente do subdesenvolvimento.

\footnotetext{
${ }^{39} \mathrm{O}$ texto de Oliveira (1976) encarrega-se de expor isso.
} 
Para os interesses desta dissertação, eis o principal constructo de Furtado. É por conta dele que a carreira e a obra do economista brasileiro, vistas em conjunto, formam a busca por um desenvolvimento capitalista que seja nacional, isto é, que não esteja submetido ao escrutínio de apenas uma pequena parcela da sociedade e da população nacionais (as elites) e que a utilização do excedente econômico aqui produzido seja feita de acordo com as condições e as necessidades locais, e não conforme padrões miméticos de consumo e de vida (vindos dos centros capitalistas). É nesse sentido que um desenvolvimento efetivo somente pode ser alcançado se o "campo de força" do subdesenvolvimento e da dependência externa for rompido; sem isso, não há desenvolvimento, apenas modernização e mais subdesenvolvimento.

Por outro lado, é importante frisar que a ênfase furtadiana na Nação não pode ser confundida com laivos autoritários, de quem deseja construir a sociedade nacional a ferro e fogo. Tal leitura poderia ter como mote inicial o papel preponderante que Furtado (tal qual a Cepal) delega ao Estado, como o dispositivo que se coloca por sobre as classes sociais e que dá a racionalidade de que carece a sociedade ${ }^{40}$, aparentemente de cima para baixo. De fato, no mais das vezes a política aparece em Furtado como uma derivação da economia, quer dizer, o poder de cada classe ou segmento social parece provir diretamente, sem mediações, dos postos que ocupam na produção e na reprodução do sistema econômico e social em voga, ou seja, quanto mais próximos do eixo dessa produção mais poder desfrutam; se ali não têm lugar, automaticamente não detêm nenhum poder (Oliveira, 1998). E no que toca ao Estado, se bem a concepção furtadiana renda resultados inesperados porém primorosos ${ }^{41}$, há que se reconhecer que não é esclarecido de onde vem sua potência e que seu estofo político jamais é exposto, bem keynesianamente. Como afirma Rodríguez em referência à Cepal,

\footnotetext{
${ }^{40}$ R. M. Marini (1994: 143) pensa que esta perspectiva do Estado alimenta uma "visão idílica do mundo".

${ }^{41}$ Referindo-se a Formação, Oliveira diz: "A relação entre economia, sociedade, política e Estado é primorosamente reestruturada pela interpretação da crise dos anos 30. São os interesses das classes sociais, dos proprietários, dos produtores, dos exportadores que levam o governo às medidas de salvaguarda dos preços - impossível frente à conjuntura internacional - e da renda, finalmente, com a estocagem e queima de café, no conhecido esquema furtadiano. Ora, aí se reinterpretam todas essas relações. Sem nomeá-las de um modo à la Marx, e conhecendo todas as resistências do autor em assimilar sua obra ao campo marxista (...), eu diria que essa passagem é construída pelo mesmo prisma com que Marx escreveu o 18 brumário de Luís Bonaparte (...)" (Oliveira, 1997: 16). Mais adiante (p. 17) ele arremata: "Acredito que o tipo de solução dado a um Estado de classes que, keynesianamente, supera as limitações de sua própria base social para preservar as condições gerais de reprodução do sistema e, nesse processo, contribui para mudar as próprias condições dessa reprodução é basicamente marxista".
} 


\begin{abstract}
"Por contraste, vê-se que o estado [sic] não constitui um objeto específico de estudo, mas que é enfocado como um agente da política econômica, encarregado de corrigir, com sua ação consciente, as distorções próprias da evolução e funcionamento do sistema econômico periférico. Portanto, ainda que não seja considerado alheio ao sistema, o estado é visto como uma entidade que lhe é externa, e capaz de atuar deliberadamente sobre ele" (Rodríguez, 1981: 171).
\end{abstract}

Entretanto, malgrado o exposto, há aí uma virtude que não é de pouca monta. Quer dizer, Furtado mantém-se fiel a seus princípios, de modo que o diagnóstico do subdesenvolvimento brasileiro não o leva a sucumbir à tentadora mas tenebrosa senda do autoritarismo, como fizeram alguns de seus antecessores. Isso é importante, pois diferentemente dos clássicos do autoritarismo brasileiro (Oliveira Vianna, Alberto Torres etc.), para Furtado o atraso brasileiro não justifica que o Estado tente transformar a economia e, principalmente, a sociedade a ferro e fogo. Daí que a obra furtadiana constituase em um "diálogo inconsútil, invisível, sem traço" com os clássicos do autoritarismo; numa palavra, trata-se de uma maneira de pensar o papel do Estado brasileiro na economia e na sociedade durante a transição para as relações sociais industriais sem resvalar no autoritarismo (Oliveira, 1997: passim). Se para tais clássicos o Estado forte é necessidade básica para uma sociedade infantilizada, para Furtado a questão é outra. Rejeitando o fácil e envolvente caminho do autoritarismo como o modus operandi de superar o subdesenvolvimento, o que seria muito simples justificar e mais ainda de implementar (basta ver a história brasileira), Furtado tem como um de seus objetivos, como o mostra Cepêda, a defesa e a busca da democracia política e econômica. Com efeito, o que Furtado quer é, inspirado em Mannheim e Myrdal, mas também em Lipset, conciliar planejamento (desenvolvimento) e liberdade, mantendo-se a legitimidade política do Estado para assim agir (Cepêda, 1998: 222-229) — relativizando assim as idéias que podem ser sugeridas pela expressão de Mantega (1995: 43), que vê nesse Estado um ente "neo-hegeliano". Daí que tomar Furtado como um autor autoritário é precisamente uma subversão de seus ideais norteadores $^{42}$.

\footnotetext{
${ }^{42}$ Como o faz, de certa maneira, Moraes (1995). No trabalho de Santos está escrito: "Algo que se pode dizer de Furtado, com grande possibilidade de acerto, é que ele se constitui como um pensador mobilizado pela possibilidade de reformar/organizar a sociedade pelo alto (...) Daí que não só seus vínculos — quando possível —, como a lente de sua objetiva fazem do Estado-nação seu locus privilegiado. Por sua vez, Estado, nação, povo, território, cultura, sociedade e economia são termos possíveis de intercâmbio no transcorrer de seu discurso" (Santos*, 1998: 86). Não me parece ser essa uma proposição acertada; pois embora o Estado nacional seja de fato uma das peças centrais no esquema furtadiano, dizer que há ali pretensões de construir a
} 
"O conjunto da reflexão intelectual brasileira deste século se debatia nas questões de como firmar a Nação diante dos sérios empecilhos das desigualdades nacionais, do localismo político, da fragilidade econômica e da distância que nos separava de um ideário de modernidade balizado pela industrialização, pela existência de relações políticas mais democráticas e pelo aumento do padrão de vida da população. A teoria formulada por Celso Furtado (independente de seus erros e acertos) é um esforço estupendo de responder a todas essas polêmicas. E mais, seguindo as influências aparentemente mais progressistas de seu tempo, ao mesmo tempo que procurava adaptá-las ao cenário particular das economias subdesenvolvidas" (Cepêda, 1998: 228, grifos meus).

Assim, bem esclarecido o papel que o Estado desempenha na consolidação da sociedade nacional, não se pode negar importância à proposta furtadiana. Uma proposta que, é lícito dizer, intenta estabelecer uma Nação que englobe as várias camadas e os vários setores da população, que não seja excludente e que seja capaz de submeter a seus desígnios os impulsos e os dinamismos vindos do sistema capitalista internacional, isso tudo sem recurso a expedientes autoritários. Somente assim, com superação do subdesenvolvimento, ruptura da dependência externa e consolidação da sociedade nacional é que um efetivo desenvolvimento capitalista brasileiro será factível, pensa Furtado. É daí que vem a radicalidade de sua interpretação, da indissociabilidade desses termos. Radicalidade que, procurando sanar os pontos fracos do dual-estruturalismo cepalinofurtadiano, os "estudos sobre a dependência" de Fernando Henrique Cardoso vão amainar, como veremos no próximo capítulo.

sociedade "pelo alto" elide o que é essencial, o compromisso de Furtado com um desenvolvimento que englobe toda a sociedade e que respeite os valores democráticos; desde sempre ele mantém a democracia como valor inatacável e como bem a ser alcançado pelo desenvolvimento brasileiro. Se Furtado sempre esteve no fio da navalha, ele sempre teve seguro para si o papel do Estado numa sociedade subdesenvolvida, desde logo um papel progressista; não fosse assim, não haveria diferença entre ele e os clássicos do autoritarismo brasileiro. 


\section{CAPÍtulo 2 \\ A SUBORDINAÇÃO DA NAÇÃO: \\ FERNANDO HENRIQUE CARDOSO E A MANUTENÇÃo \\ DA DEPENDÊNCIA}

\section{Revisões do dual-estruturalismo e origens dos estudos sobre a dependência}

Não deve restar dúvidas sobre a percuciência teórica e prática na América Latina do dual-estruturalismo projetado pela Cepal e levado à sua melhor expressão por Celso Furtado. O capítulo precedente procurou esboçar tal relevância, sobretudo quando vista desde a perspectiva da questão nacional - nervo do pensamento furtadiano; relevância essa que, entretanto, não livrou dito esquema interpretativo de alguns problemas, rapidamente indicados.

São os desdobramentos do pensamento cepalino-furtadiano - inclusive suas debilidades - que nos interessam agora. Mais precisamente: fora dito que, para o pensamento cepalino-furtadiano, a industrialização (capitaneada pelo Estado) tirar-nos-ia da condição periférica e levar-nos-ia para longe do subdesenvolvimento. Com efeito, observando-se o Brasil, é fato que a industrialização avançou consideravelmente, isto é, a produção industrial cresceu, as exportações assumiram (ou começaram a assumir) perfis menos primário-exportadores e o país acentuou sua urbanização ${ }^{1}$. Numa palavra, parecia

\footnotetext{
${ }^{1}$ Em números: se a taxa de crescimento anual média do Produto Interno Bruto (PIB) entre 1945 e 1980 beirou os $7,1 \%$, o crescimento do setor manufatureiro, nesses mesmos parâmetros, foi de $9 \%$; já a participação do
} 
que a pregação industrialista da Cepal (convertida no "desenvolvimentismo") ia se tornando realidade. No entanto, a partir do início dos anos 1960 foi-se evidenciando pouco a pouco que, a despeito dos exitosos indicadores econômicos, a transformação capitalista por que ia passando o Brasil - e a América Latina toda, pode-se dizer - não trouxera consigo a outra parte da promessa, quer dizer, não trouxera a prometida elevação do "bemestar geral" da população, avanços sociais e políticos. No que toca especificamente ao Brasil, ao crescimento econômico não se seguiu nenhuma democratização da sociedade e da política nacionais, pelo contrário - basta pensar no "milagre econômico brasileiro" (1968-1972) —, com o que ficou patente a inadequação do trinômio industrializaçãodesenvolvimento-democracia presente no pensamento de Furtado (e também no da Cepal). Em poucas palavras, embora relativamente industrializados, continuávamos subdesenvolvidos.

Naturalmente que as razões que fundamentam essas "desilusões do desenvolvimentismo" são várias e complexas, mais até do que seria possível inventariar e investigar neste capítulo da dissertação. Contudo, é lícito dizer, mesmo sucintamente, que a raiz radica justamente num ponto assinalado no capítulo anterior, vale dizer, na compreensão que o pensamento cepalino-furtadiano tem do processo capitalista e de suas relações sociais e na supervalorização dos elementos econômicos a desmedro dos elementos políticos ${ }^{2}$, que sua periodização histórica (crescimento para fora/crescimento para dentro/internacionalização dos mercados) deixa patente ao dimensionar demasiadamente o papel da economia e empanar a relevância das relações sociais e política em toda a démarche do desenvolvimento capitalista (Mello, 1991: 13-27; Fiori, 1995: 0406). Seja como for, o que importa aqui é chamar a atenção para tais desilusões e, especialmente, para os efeitos daí decorrentes.

Ora, de todos, o maior e mais significativo efeito foi o movimento de críticas e autocríticas desencadeado pelas "promessas não cumpridas” pelo esquema cepalinofurtadiano a partir de fins dos anos 1960 (Rodríguez, 1981: 273; Mantega, 1995: 41-42). Era necessário, afinal, explicar por que um processo que parecia encaminhar-se bem sofreu

setor industrial na Renda Interna passou de 26\% em 1949 para 33,4\% em 1970; no âmbito externo, nossa pauta de exportações sofreu uma considerável diversificação, com os manufaturados alcançando então mais de $60 \%$ do total exportado pelo país no final dos anos 80 (Fiori, 1993: 07-08).

${ }^{2}$ De novo, vale a pena ressaltar que não digo que não há análise dos elementos políticos do processo de desenvolvimento capitalista em Furtado, mas apenas que essa análise, que existe, é débil nalgumas partes. 
tamanha inflexão e foi mesmo desvirtuado. Ou melhor, explicar as razões de semelhante inflexão e, por que o referido esquema apresentou problemas, propor outra interpretação para o processo de desenvolvimento capitalista no Brasil e na América Latina. É nessa etapa que surgem, como um desdobramento crítico do pensamento cepalino-furtadiano, estudos que procurarão explorar melhor as condições gerais e as características mais marcantes do capitalismo na periferia latino-americana e suplantar as insuficiências do dual-estruturalismo. Uma parte desses estudos ficou posteriormente conhecida pela denominação comum de "teoria da dependência", dentre os quais têm lugar central aqueles de Fernando Henrique Cardoso.

Ponto comum às diferentes vertentes dos estudos sobre a dependência, o que anima tal movimento crítico é a percepção de que o núcleo dos problemas enfrentados pela interpretação cepalino-furtadiana está precisamente na maneira como as relações sociais e políticas postas em marcha pela industrialização foram analisadas, isto é, na consideração insuficiente da política. Sendo assim, porque teria dado peso demasiado à economia é que, nesta perspectiva, o pensamento dual-estruturalista não teria podido compreender os caminhos que o desenvolvimento capitalista brasileiro e latino-americano estava tomando, o da crescente concentração e centralização de capitais, e o papel das classes sociais no bojo desse processo. Além do mais, reflexo do que se disse, não se teria conseguido perceber igualmente que os "interesses externos" não mais se oporiam ao "interesses internos", como até então supusera a Cepal, mas uns e outros engendrariam conexões entre si. De modo que, como postulado mais geral dos estudos sobre a dependência, a compreensão efetiva do desenvolvimento capitalista na periferia necessitaria da ascensão da política ao primeiro plano da análise: noutros termos, analisar o processo econômico como um processo social e político, o que faria possível entender como o subdesenvolvimento havia persistido a despeito da industrialização. Eis como os estudos sobre a dependência procuraram rever os achados do pensamento cepalino-furtadiano, acatando alguns de seus aspectos (por exemplo, a periodização histórica é mantida quase intacta na maioria dos estudos sobre a dependência) mas refazendo outros (por exemplo e sobretudo, o peso maior atribuído à política). Passava-se então da formulação teórica do "subdesenvolvimento" à da "dependência", com o que se acreditava encontrar a chave para a resolução de vários problemas. 
Os estudos sobre a dependência são, pois, em larga e extensa medida, decorrência das desilusões a que as pregações dual-estruturalistas haviam levado toda a América Latina. Nesse sentido é que são desdobramentos críticos do pensamento cepalino-furtadiano, preservando alguns de seus pontos, rompendo com outros; é o que Cardoso já chamou de "superação no sentido hegeliano-marxista", isto é, uma "negação sem anulação". A esse respeito, é conveniente lembrarmos de que Furtado publicara em 1956, pelo Serviço de Documentação do Ministério de Educação e Cultura, um livro cujo título era, sugestivamente, Uma economia dependente ${ }^{3}$. Ademais, é digno de nota que a própria Cepal já vinha se preocupando com aspectos outros do desenvolvimento que não só o econômico, o que pode ser visto na integração em seus quadros de alguém como José Medina Echavarría, sociólogo espanhol então vivendo na América Latina e que vinha se dedicando a questões como os "aspectos sociais" do desenvolvimento econômico: Echavarría fora convocado justamente para aplacar um pouco do economicismo daquela Comissão ${ }^{4}$. Ao que parece, Echavarría exerceu influência ponderável sobre certa vertente dos estudos sobre a dependência, sobretudo sobre Cardoso e Faletto. Há também trabalhos saídos da própria órbita cepalina que já trazem registrada em seu roteiro a perspectiva de uma visão mais ampla sobre o desenvolvimento econômico, como é o caso, à guisa de exemplo, dos trabalhos de Oswaldo Sunkel e Pedro Paz (1970) 5 .

Entretanto, se os estudos sobre a dependência derivam nalguma medida do dualestruturalismo, é preciso dizer aqueles não derivam tão-somente deste, posto que o marxismo constituiu outra de suas fontes geradoras. Aliás, forçoso é frisar que, a rigor, a idéia ou noção de dependência não é um achado cepalino-furtadiano ou mesmo dos estudos ora em mira ${ }^{6}$ : os estudos mais sistematizados sobre o desenvolvimento capitalista em

\footnotetext{
${ }^{3}$ A rigor este livro é a reunião de certas seções de alguns capítulos de A economia brasileira, de 1954 (Mallorquín, 1993: 08-09).

${ }^{4}$ Pelo que diz Furtado, parece ter sido sua a sugestão a Prebisch de integrar aos quadros da Cepal um profissional das outras Ciências Sociais, sobretudo um sociólogo, sugestão que veio junto com o nome de Echavarría e que coube a Furtado efetivar (Furtado, 1985: 116-118). Nesse mesmo trecho está que "José Medina, com seu ar modesto, sem jamais forçar a passagem, viria a ser o grande mestre da sociologia do desenvolvimento na América Latina. Que o diga Fernando Henrique Cardoso, e tantos outros que com ele trabalharam em Santiago". Uma mostra do trabalho de Echavarría está em Consideraciones sociológicas sobre el desarrollo económico de América Latina, de 1964. De acordo com Jaime Osorio (1994: 169), "Não é exagerado indicar que, com os trabalhos de Medina Echavarría, começa a ganhar curso um novo ramo dentro da sociologia latino-americana, a sociologia do desenvolvimento, que alcançará seus melhores momentos com os trabalhos dos teóricos da dependência".

${ }^{5}$ Sobre essa vertente dos estudos sobre a dependência saída diretamente da Cepal, veja Palma (1987: 59-71).

${ }^{6}$ Doravante sigo a caracterização feita por Palma (1987: 23 e ss.).
} 
regiões e países "atrasados" remontam, embora não se limitem a elas, às análises do imperialismo realizadas em fins do século passado e inícios deste, com Lênin à frente. Tendo ante seus olhos, no âmbito mundial, o período de transição do capitalismo concorrencial ao monopolista e, no local, a situação russa, Lênin pôde acompanhar e estudar com acuidade o movimento de avanço e penetração monopólica do capitalismo o imperialismo — pelos países menos desenvolvidos; com isso, foi pioneiro na interpretação das dificuldades e possibilidades da industrialização tardia e no questionamento da circunstância de que alguns países, a despeito de formalmente independentes, permaneciam de fato "envoltos nas redes de dependência financeira e diplomática" (Lênin, 1971: 105, grifos meus). Lançadas pois suas bases, esses trabalhos serão posteriormente remoçados quando, por volta dos anos 1940 e 1950, encontram fôlego novo em autores como P. Sweezy e P. Baran que, entre outros, dedicaram-se desde então à pesquisa do desenvolvimento capitalista do ponto de vista marxista (Mantega, 1995: 215216). Não é ocioso lembrar que Sweezy e Baran estão na base e fornecem o substrato teórico para os escritos de André Gunder Frank e, em certo sentido, também para os de Ruy Mauro Marini e os de Theotônio dos Santos, a denominada corrente "marxista" dos estudos sobre a dependência (Kay, 1991: 49-51).

Todavia, a participação do marxismo no impulso dos estudos sobre a dependência não se restringe a aportes digamos "teóricos", mas contribui também formando a ambiência em que eles são arquitetados. Ou seja, quero dizer que a década de 1960 marca um momento especial para a América Latina, para o qual o marxismo em muito colaborou ${ }^{7}$. De um lado, há todo um esforço de elaboração de um marxismo com sabor latinoamericano, um marxismo pensado tanto para interpretar a realidade local a partir de suas próprias características quanto para escapar ao esquematismo que teimava em entender o marxismo como um modelo universal a ser aplicado "procustianamente" em todo lugar note-se que, interessantemente, há aqui uma dupla reprodução: na pretensão de pensar a América Latina por intermédio de seus próprios termos, o movimento cepalino de sintetizar uma teoria do desenvolvimento especificamente latino-americana e, na busca por um marxismo nosso, as intenções que estavam presentes nas obras seminais de Haya de la Torre e Mariátegui. De outro lado, a reverberação política e social da Revolução Cubana e

\footnotetext{
${ }^{7}$ Devo o que vem a seguir basicamente a Portantiero (1989).
} 
sua ampliação quando do anúncio de seu caráter socialista em 1961, bem como de outros movimentos de esquerda e/ou socialistas pelo mundo afora, viriam acender a chama de perspectivas transformadoras e ratificar a crença na possibilidade de mudança de realidades adversas como a do subdesenvolvimento (Faletto, 1998; Santos, 1998).

Tudo somado, o desdobramento crítico do pensamento cepalino-furtadiano e a crescente influência das análises de cunho marxista, o que vai se estabelecer por sobre esse piso a partir dos anos 60 na América Latina são os supracitados estudos sobre a dependência ${ }^{8}$. Naturalmente que há outras colunas que sustentam esses estudos, mas essas são as principais, que fecundam diferentemente os autores aqui arrolados: uns portam mais heranças dos mestres cepalinos, outros do legado marxiano e marxista. De todo modo, o resultado é que, não obstante suas distinções (que são significativas), esse autores procuram desvendar analiticamente e a um só tempo a mesma problemática, labor múltiplo que decanta uma linha-mestra que se encontra abrigada nos estudos sobre a dependência.

Entendido isso, há que deixar claro que, dentro dessa multiplicidade de estudos sobre a dependência ${ }^{9}$, o foco deste capítulo repousará sobre os trabalhos de Fernando Henrique Cardoso, representante destacado da vertente "reformista" — para novamente lançar mão da terminologia de Kay (1991: 49-51). E, tomados os trabalhos de Cardoso, há uma perspectiva especial em interesse: enquanto o capítulo anterior versou sobre o lugar central que Furtado, em seu pensamento, delega à Nação e como sua preocupação com consolidação da sociedade nacional converte-se numa teoria da superação do subdesenvolvimento (na qual subdesenvolvimento e Nação são termos excludentes), aqui o que deve chamar nossa atenção é como Cardoso equaciona a mesma questão da Nação, isto

\footnotetext{
${ }^{8}$ Mais descrições sobre os antecedentes dos estudos sobre a dependência podem ser encontrados em Cardoso (1993: 81-90), Love (1990), O’Brien (1975; 1985) e Palma (1987). Para uma crítica que vê a "teoria da dependência" como uma "obviedade histórica", consulte Machado (1999). Faletto e Santos, cada qual a sua maneira, fazem nos textos já citados (ambos de 1998) relatos interessantes, como o são os daqueles que tomaram parte nessa história, sobre o ambiente no qual vicejaram os estudos sobre a dependência, sobre o Chile e a América Latina daquela época e os vários centros de pesquisas onde esses estudos tiveram lugar (Cepal, Instituto Latinoamericano de Planificación Económica y Social (ILPES), Centro de Estudios Sócioeconómicos (CESO), etc.).

9 A propósito dessa multiplicidade, Palma vê três enfoques na "teoria da dependência": um que insiste na impossibilidade de desenvolvimento capitalista na periferia, consubstanciado nas formulações de, entre outros, Ruy Mauro Marini, Theotônio dos Santos e André Gunder Frank (o conhecido "desenvolvimento do subdesenvolvimento"); um que se centra na análise dos obstáculos ao desenvolvimento capitalista na periferia, bem representado pelos trabalhos de Furtado posteriores a 1964; e, finalmente, um enfoque que privilegia a possibilidade de desenvolvimento capitalista na periferia, que o caso da corrente iniciada por
} 
é, a relação entre desenvolvimento capitalista e Nação. Há em Cardoso a mesma incompatibilidade entre sociedade nacional e subdesenvolvimento que em Furtado? Como a noção de dependência entra nesse arranjo e a que préstimos serve? Em outras palavras, qual o lugar da Nação para Cardoso?

Que fique estabelecido desde já o que pretendo indicar nesse capítulo: apesar de existente, a Nação — ou sociedade nacional — sofre um deslocamento no esquema teórico de Cardoso em relação ao de Furtado. Qualificando melhor, se na interpretação furtadiana o subdesenvolvimento impedia precisamente a consolidação nacional, em Cardoso este nexo é rompido: é possível angariar algum desenvolvimento capitalista sem que as amarras do subdesenvolvimento sejam rompidas, ou seja, a questão da Nação, enquanto "internalização dos centros de decisões" e elevação do "bem-estar geral" da população, deixa de ser passo necessário para se lograr o desenvolvimento capitalista. Segundo Cardoso, os laços que atrelam centro e periferia capitalistas são outros, mais articulados e menos estanques; interesses externos e internos não se opõem, antes podem andar juntos; e, especialmente, a compreensão do processo de desenvolvimento capitalista brasileiro só pode ser feita se se levar em conta os jogos políticos entabulados pelas classes sociais daqui de dentro. Por fim, tal quadro seria melhor especificado pelo recurso à noção de dependência. Trata-se assim de tirar proveito da margem de manobra que a dependência franqueia a um país como o Brasil, sem que com isso se supere necessariamente o subdesenvolvimento. Daí que - e isso é o que importa deixar em evidência - as formulações de Cardoso, conforme veremos, assumem o aspecto de uma teoria da acomodação da Nação aos movimentos do sistema capitalista internacional, sem questionar nossa posição aí dentro. Há sim uma idéia de Nação para Cardoso, mas ela nem de longe tem a mesma relevância e a mesma gravidade que tem para Furtado.

Nesse sentido, lembrando o que se disse mais atrás — que os estudos sobre a dependência têm pontos tanto de continuidade quanto de ruptura com o pensamento cepalino-furtadiano - , a matéria deste capítulo será um desses pontos de ruptura (quiçá um dos principais). As comparações entre uma e outra postura, e as considerações que daí podem ser retiradas, serão objeto do próximo capítulo.

Fernando Henrique Cardoso e Enzo Faletto (depois continuada apenas por Cardoso) representa bem. Cf. PALMA (1987: 48-49). 
Porém, antes de iniciar tal tarefa, duas observações. Primeiro, das minhas referências aos estudos sobre a dependência e, dentro desses, aos trabalhos de Cardoso, não deriva nenhuma desqualificação das outras vertentes desses estudos, sobretudo os da corrente marxista, quer dizer, Marini e Dos Santos principalmente; embora com resultados diversos (e criticáveis, está claro), esses trabalhos foram e são tão importantes quanto os de Cardoso; contudo, por motivos de tempo e espaço, escolhas devem ser feitas na execução da dissertação, e assim o foram. Daí que as menções aos referidos trabalhos têm menos a intenção de analisá-los que a de servirem para iluminar o pensamento de Cardoso — posto que nos debates e nas polêmicas com a vertente marxista a análise "cardosiana" tem um momento especial de expressão. Segundo, creio que chamar de "estudos sobre a dependência" àquilo que ficou conhecido como "teoria da dependência" tem algumas virtudes. Por um lado, fica esclarecido que não há uma "teoria" assim como há uma "teoria da relatividade" (com princípios, conceitos, hipóteses etc.) ${ }^{10}$, por outro ilumina-se o fato de que são análises e aportes interpretativos bastante diversos que, sob a rubrica de "teoria da dependência", aparecem indiferenciados. Assim, "estudos sobre a dependência" contempla melhor os pontos assinalados: não apaga a diversidade entre estudos (Palma, 1987: 21) e deixa claro que há menos uma teoria que uma "problemática" em foco (Weffort, 1971: 03). Assinale-se, enfim, que a expressão "estudos sobre a dependência" já aparecia utilizada por Cardoso em um de seus textos (1975b).

\section{Do subdesenvolvimento à dependência: política e economia em primeiro plano}

O marco fundador dos estudos sobre a dependência na corrente "reformista" (Kay, 1991: 46 e ss.) está em Dependência e desenvolvimento na América Latina, trabalho do

\footnotetext{
10 "E, rigorosamente, não é possível pensar numa 'teoria da dependência'. Pode haver uma teoria do capitalismo e das classes, mas a dependência, tal como a caracterizamos, não é mais que a expressão política, na periferia, do modo de produção capitalista quando este é levado à expansão internacional" (Cardoso, 1971: 32).
} 
brasileiro Fernando Henrique Cardoso e do chileno Enzo Faletto escrito entre 1966 e 1967, sob o abrigo do Instituto Latinoamericano de Planificación Económica y Social (ILPES), em Santiago do Chile, e publicado pela primeira vez em forma de livro em 1969 (Cardoso \& Faletto, 1973); é aí que está corporificada, se não pela primeira vez ${ }^{11}$, ao menos de modo articulado o conjunto de idéias e teorizações que farão fortuna nas Ciências Sociais latinoamericanas (e mesmo mundiais) e cuja continuação caberá em essência a Cardoso.

$\mathrm{Na}$ fonte desses estudos está, como já se disse, a identificação dos problemas ocasionados pela perspectiva dual-estruturalista acerca do processo de desenvolvimento capitalista latino-americano, isto é, a forte constatação de que, apesar de condições econômicas conjunturais e estruturais propícias, o desenvolvimento geral prometido pelo pensamento cepalino-furtadiano não estava se efetivando (Cardoso \& Faletto, 1973: 09-12). Era necessário explicar as razões de o processo histórico-social não correr conforme o previsto, razões que, como também já se disse, foram localizadas na desvalorização dos elementos políticos em favor dos econômicos, ou seja, na lógica do pensamento cepalinofurtadiano: como os próprios autores escrevem, "Em uma primeira aproximação fica, pois, a impressão de que o esquema interpretativo e as previsões que à luz de fatores puramente econômicos podiam formular-se ao terminar os anos 1940 não foram suficientes para explicar o curso posterior dos acontecimentos" (Cardoso \& Faletto, 1973: 13). Ou seja, o entendimento do desenvolvimento capitalista latino-americano fornecido pelo dualestruturalismo cepalino-furtadiano não teria sido exitoso por haver deixado de lado os fatores políticos, isto é, por haver tratado o processo de desenvolvimento apenas como um processo econômico. No texto citado, após menção aos casos do Brasil, da Argentina e do México, os dois primeiros como exemplos de processos de desenvolvimento que não deslancharam e o último como exceção que conseguiu lograr algum avanço, vem a pergunta:

\footnotetext{
“À luz desses fatos, pode-se generalizar a sugestão implícita na pergunta sobre as causas da insuficiência dinâmica das Economias nacionais que apresentavam perspectivas tão favoráveis como no caso da Argentina. Até que ponto o fato mesmo da Revolução mexicana, que rompeu o equilíbrio das forças sociais, não terá sido o fator fundamental do desenvolvimento alcançado posteriormente? Não terão sido os fatores inscritos na estrutura social brasileira, o jogo das forças políticas e sociais que atuaram na década 'desenvolvimentista', os responsáveis tanto do resultado favorável como da
}

\footnotetext{
${ }^{11} \mathrm{O}$ assunto já vinha sendo explorado pelos autores em versões preliminares do texto.
} 
perda do impulso posterior do processo brasileiro de desenvolvimento?" (Cardoso \& Faletto, 1973: 14, itálicos meus).

Quer dizer, como a passagem acima deixa implícita (ao trazer em germe o fulcro da abordagem que Cardoso ampliará depois), a compreensão mais apurada do desenvolvimento capitalista brasileiro e latino-americano deve, segundo Cardoso e Faletto, ser buscada na estrutura social da região e nos "jogos das forças políticas e sociais" aí engendrados. Dizendo diferentemente, o processo econômico do desenvolvimento capitalista deve ser pensado e analisado como um processo igualmente político e social: eis a chave para o entendimento do que ocorrera na América Latina e do que viria a acontecer. Entretanto, como bem fazem notar Cardoso e Faletto, tal chave não requer somente que se troque um enfoque econômico por um equivalente sociológico, o que seria incorrer no mesmo equívoco do pensamento dual-estruturalista, apenas que com sinal invertido. É necessário mais que isso.

\begin{abstract}
"Ainda que os graus de diferenciação da estrutura social dos diversos países da região condicionem de forma diversa o crescimento econômico, não é suficiente substituir a interpretação 'econômica' do desenvolvimento por uma análise 'sociológica'. Falta uma análise integrada que forneça elementos para dar resposta de forma mais ampla e matizada às questões gerais sobre as possibilidades do desenvolvimento ou estagnação dos países latino-americanos, e que responda às perguntas decisivas sobre seu sentido e suas condições políticas e sociais" (Cardoso \& Faletto, 1973: 15).
\end{abstract}

O trabalho de Cardoso e Faletto constitui, pois, uma tentativa de fornecer tais "análises integradas" referidas acima, explicitando assim um suposto "passo além" do que houvera sido feito pelo pensamento cepalino-furtadiano. Dessa maneira é que o desenvolvimento capitalista na periferia passa a ser entendido menos como uma mera injunção externa que é absorvida ipsis litteris pelos países subdesenvolvidos que como uma função das condições sociais históricas internas, com isso entendidas as modalidades, formas, dinâmicas e características assumidas pelas relações entre as classes sociais; ou seja, embora as vicissitudes do desenvolvimento não estejam desgarradas do exterior, não são por ele determinadas mecanicamente, como se as relações entre os países fossem feitas à moda de blocos monolíticos, ou como se a periferia fosse um epifenômeno do centro capitalista. Pelo contrário, o que pretendem Cardoso e Faletto é sustentar que todo esse processo passa forçosamente pelas lutas e conflitos engendrados pelas classes sociais locais: numa palavra, o modo de organização e interação destas (e do padrão de dominação 
política) dá a performance do desenvolvimento capitalista, isto é, da acumulação capitalista. Donde fica evidente que tal enfoque procura lançar luz sobre os estreitos laços que atam economia e política.

Sendo assim, e criticando as análises tipológicas de sociedades "tradicionais" e "modernas" ou as análises de mudança social (as teorias da modernização), esta proposta de procedimento metodológico preconiza que a análise (por exemplo) do desenvolvimento capitalista brasileiro deve pôr ênfase no "tipo de integração social das classes e grupos como condicionantes principais do processo de desenvolvimento" (Cardoso \& Faletto, 1973: 20-21). De maneira semelhante, quer-se deixar de ver os âmbitos interno e externo como termos opostos e sem o recurso a uma "contradição formal e indeterminada" — como Cardoso esclarecerá depois (1971: 32). Trata-se, portanto, de elaborar uma interpretação que supere a simples recomendação da industrialização como saída do subdesenvolvimento indagando sobre suas repercussões sociais e políticas e que dê a devida proporção às lutas sociais internas historicamente desenhadas, vale dizer, como processos históricos e não somente estruturais — daí a idéia de "procedimento histórico-estrutural" pensada por Cardoso e Faletto.

\footnotetext{
"Trata-se, por conseguinte, de buscar uma perspectiva que permita vincular concretamente os componentes econômicos e os sociais e não só justapô-los. Isso supõe que a análise ultrapasse a abordagem que se pode chamar de enfoque estrutural, reintegrando-a em uma interpretação feitas em termos de 'processo histórico' " (Cardoso \& Faletto, 1973: 21-22).
}

Desta feita, falar em lutas e conflitos sociais como formuladores do desenvolvimento capitalista é indicar a primazia das "estruturas de dominação", de modo que nesta perspectiva

“(...) o problema teórico fundamental é constituído pela determinação dos modos que adotam as
estruturas de dominação, porque é por seu intermédio que se compreende a dinâmica das relações
sociais (...) Esta opção teórica fica apoiada empiricamente pelo fato de que as transformações
históricas significativas do processo de desenvolvimento latino-americano têm sido sempre
acompanhadas, senão de uma mudança radical na estrutura de dominação, pelo menos pela adoção
de novas formas de relaçães, e portanto de conflitos, entre as classes e grupos” (Cardoso \& Faletto,
1973: 22-23).

Torna-se claro então que, para ser inteligível, a situação econômica de um país deve ser vista integrada com suas transformações sociais e políticas. Vale dizer, a economia do 
país e seu processo de desenvolvimento capitalista tornam-se inteligíveis por intermédio de sua política e sua sociedade. Ora, esse foco específico de análise procura atentar para aquilo que o pensamento cepalino-furtadiano havia deixado na penumbra teórica, de modo que Cardoso e Faletto redimensionam a noção de desenvolvimento e passam a vê-lo

“(...) como resultado da interação de grupos e classes sociais que têm um modo de relação que lhes é próprio e, portanto, interesses materiais e valores distintos, cuja oposição, conciliação ou superação dá vida ao sistema sócio-econômico. A estrutura social e política vai-se modificando na medida em que diferentes classes e grupos sociais conseguem impor seus interesses, sua força e sua dominação ao conjunto da sociedade" (Cardoso \& Faletto, 1973: 22).

O exposto estabelece claramente que Cardoso e Faletto não desprezam a noção de desenvolvimento/subdesenvolvimento, porém dão-lhe novo enquadramento. Justamente esse novo enfoque e essa abordagem distinta (em relação ao dual-estruturalismo) necessitam de categorias capazes tanto de captar a dinâmica das transformações históricas das estruturas de dominação quanto de interpretar as relações externo/interno sem cair no mecanicismo do externo determinando ferreamente o interno, necessidade que é contemplada, segundo Cardoso e Faletto, pela idéia de "dependência". Assim é que a noção de dependência é aqui invocada para colaborar nas tentativas de compreensão do desenvolvimento capitalista latino-americano, e é justificada nos seguintes termos:

\footnotetext{
"Precisamente o conceito de dependência, que mais adiante será examinado, pretende outorgar significado a uma série de fatos e situações que aparecem conjuntamente em um momento dado e busca-se estabelecer, por seu intermédio, as relações que tornam inteligíveis as situações empíricas em função do modo de conexão entre os componentes estruturais internos e externos. Mas o externo, nessa perspectiva, expressa-se também como modo particular de relação entre grupos e classes sociais no âmbito das nações subdesenvolvidas. É precisamente por isso que tem validez centrar a análise da dependência em sua manifestação interna, posto que o conceito de dependência utiliza-se como um tipo específico de conceito 'causal-significante' —implicações determinadas por um modo de relação historicamente dado - e não como conceito meramente 'mecânico-causal', que enfatiza a determinação externa, anterior, que posteriormente produziria 'conseqüências' internas" (Cardoso \& Faletto, 1973: 23).
}

Eis pois a noção de dependência segundo a vertente teórica representada por Cardoso e da qual derivará toda uma linhagem de trabalhos e análises do desenvolvimento capitalista na América Latina (e mesmo fora dela, porém nem sempre com resultados 
alentadores ${ }^{12}$ ). Entretanto, para que essa empreitada teórica e metodológica se justifique, não basta simplesmente nomear algo, é forçoso indicar claramente em que medida a noção de dependência é de fato um avanço em relação ao desenvolvimento/subdesenvolvimento, ou seja, é mister esclarecer em que medida não se está apenas dando dois nomes para a mesma coisa. Sendo assim, Cardoso e Faletto prosseguem dizendo que de certo modo o esquema de economias "centrais" e "periféricas" parece ser mais adequado que aquele de economias "desenvolvidas" e "subdesenvolvidas" por comportar distinções posicionais e funcionais no bojo do sistema capitalista internacional, no entanto o câmbio de um pelo outro não seria correto, por significações teóricas diversas que têm. Nesse sentido é que, embora não mutuamente excludentes, as noções de "desenvolvimento/subdesenvolvimento", "centro/periferia" e "autonomia/dependência" dizem respeito a aspectos distintos do desenvolvimento capitalista — daí a validade da noção de dependência. No entender dos autores, "a noção de dependência alude diretamente às condições de existência e funcionamento do sistema econômico e do sistema político, mostrando a vinculação entre ambos, tanto no que se refere ao plano interno dos países quanto ao externo", enquanto que a de subdesenvolvimento refere-se quase que exclusivamente ao grau de diferenciação do sistema produtivo do país (sem atentar para como se dá o controle social da produção) e as de centro e periferia apenas indicam o lugar do país no sistema capitalista internacional (sem mencionar os fatores político-sociais aí envolvidos) (Cardoso \& Faletto, 1973: 27).

Essa transição de uma noção de subdesenvolvimento a uma de dependência é importante, tanto porque dá o pavimento e a urdidura das posteriores análises sociológicas de Cardoso quanto porque residem neste ponto os interesses deste capítulo da dissertação. Com efeito, mesmo sem dizê-lo explicitamente, é aqui que Cardoso e Faletto pensam ter ido além do pensamento cepalino-furtadiano ao, num só passo, demonstrar os limites da noção de subdesenvolvimento (atenta apenas à configuração econômica do sistema produtivo) e aprimorar a interpretação do desenvolvimento capitalista na periferia latinoamericana com a convergência necessária de fatores político-sociais e econômicos, externos e internos, conseguindo captar o fato, para Cardoso e Faletto evidente naquela quadra do capitalismo em meados dos anos 1960, de que as relações entre países não se dão

\footnotetext{
${ }^{12}$ Sobre a utilização desta perspectiva teórica fora das fronteiras da América Latina, consulte, de Cardoso
} 
mais entre países industrializados e primário-exportadores somente, mas entre países com graus variados de industrialização. Além do mais, é esse artifício que lhes permite dissociar a diferenciação do sistema econômico da formação de centros autônomos (internos) de decisão, peça fundamental no arcabouço furtadiano, ou seja, passa a ser teoricamente possível que um país modifique seu sistema produtivo (incrementando-o pela industrialização e crescimento, por exemplo) sem que isso implique superação da dependência. Quer dizer, é a operação acima relatada que abrirá a Cardoso o caminho à idéia de "desenvolvimento dependente", ou de desenvolvimento na dependência, que veremos em mais detalhes adiante.

As repercussões desse procedimento, está claro, não podem ser eludidas e já aqui podem ser vistos os pontos de diferenciação entre os estudos sobre a dependência de Cardoso e a interpretação do subdesenvolvimento de Celso Furtado que desejo ressaltar nesta dissertação. Enquanto para Furtado, conforme vimos, a defesa da sociedade nacional (constituição de centros internos de decisão) exige necessariamente a superação do subdesenvolvimento e da condição periférica do país (Nação e subdesenvolvimento são antípodas), Cardoso será levado por seus achados a supor tal oposição como indevida, quer dizer, que é possível lograr algum desenvolvimento sem que os laços de dominação externa sejam cortados; nesse aspecto, a consolidação nacional não exige o questionamento da estruturação do sistema capitalista internacional (a Nação se acomoda a esse sistema) ${ }^{13}$. Evidentemente que a abordagem explorada por Cardoso terá suas vantagens, por exemplo ao mantê-lo distante das teses estagnacionistas que grande parte do pensamento social e político brasileiro (inclusive Furtado) esposou logo após o Golpe Militar de 1964; entretanto, fato é que, se há continuidades e rupturas entre o pensamento cepalinofurtadiano e os estudos sobre a dependência, este é decerto um dos de maior ruptura, posto que, levado ao limite, o enfoque teórico de Cardoso deixa patente que o problema da consolidação nacional deixa de ter relevância e, mais, converte tais idéias e tal interpretação numa "teoria da acomodação" da Nação às condições ditadas pelo sistema capitalista internacional. Todavia, tal consideração necessita ser fortalecida com a agregação de mais elementos, o que será feito depois.

(1993: 125-149), "O consumo da teoria da dependência nos Estados Unidos".

13 "A antiga dicotomia estabelecida pela Cepal entre industrialização nacional e dependência é superada" (Goldenstein, 1994: 42). 
Seja como for, embora o que quero indicar neste capítulo deva ficar mais claro com o avançar da argumentação, há ocasiões em que o próprio Cardoso, agora apenas ele, cuida de ressaltar seu distanciamento com relação a alguns aspectos da Cepal:

\begin{abstract}
"A novidade das análises da dependência não consistiu, portanto, em sublinhar a dependência externa da economia que já fora demonstrada pela CEPAL. Ela veio de outro ângulo: veio da ênfase posta na existência de relações estruturais e globais que unem as situações periféricas ao Centro. Os estudos sobre a dependência mostravam que os interesses das economias centrais (e das classes que as sustentam) se articulam no interior dos países subdesenvolvidos com os interesses das classes dominantes locais. Existe pois uma articulação estrutural entre o Centro e a Periferia e esta articulação é global: não se limita ao circuito do mercado internacional, mas penetra na sociedade, solidarizando interesses de grupos e classes externos e internos e gerando pactos políticos entre eles que desembocam no interior do Estado" (Cardoso, 1993: 19).
\end{abstract}

Entendido isso, resta a interrogação: afinal, como viabilizar tal abordagem, quer dizer, como verificar concretamente tais articulações? Em seu esquema, Cardoso e Faletto respondem que "o problema do controle social da produção e do consumo constituem o eixo de uma análise sociológica do desenvolvimento orientada desta perspectiva" (Cardoso \& Faletto, 1973: 24, grifos meus). Assim, é pela investigação do "controle social da produção" que se poderá compreender "histórico-estruturalmente" como as relações sociais e seus conseqüentes conflitos moldam o desenvolvimento capitalista em cada país e como se relacionam com o movimento capitalista internacional (Cardoso \& Faletto, 1973: 29$30)^{14}$. Para tanto os autores tipificam duas modalidades de controle da produção na América Latina: os casos de "enclaves coloniais", que são aqueles em que o controle da produção ficou em mãos estrangeiras (Cardoso \& Faletto, 1973: 46-51); e os casos de "controle nacional do sistema produtivo", aqueles em que, por conta e obra do processo histórico e social, o controle da produção foi mantido em poder das classes sociais locais, como ocorreu no Brasil (Cardoso \& Faletto, 1973: 42-46).

É na compreensão e na operação deste engenho teórico que Cardoso e Faletto acreditam ter encontrado a inteligibilidade dos processos de desenvolvimento capitalista na América Latina (Cardoso \& Faletto, 1973: 52-90):

\footnotetext{
${ }^{14}$ À p. 30 Cardoso e Faletto escrevem que "o que se pretende ressaltar é que o modo de integração das economias nacionais no mercado internacional supõe formas definidas e distintas de inter-relação dos grupos sociais de cada país, entre si e com os grupos externos. Pois bem, quando se aceita a perspectiva de que os influxos do mercado, por si mesmos, não são suficientes para explicar a mudança nem para garantir sua continuidade ou sua direção, a atuação das forças, grupos e instituições sociais passa a ser decisiva para a análise do desenvolvimento".
} 
“(...) a hipótese desenvolvida neste trabalho postula que os padrões de integração social e os tipos de movimentos sociais, por intermédio dos quais se foi direcionando a vida política e o perfil das sociedades latino-americanas, assumiram conotações distintas conforme se tratasse de países onde foi possível manter o controle nacional do sistema exportador ou, pelo contrário, naqueles onde a economia de enclave prevaleceu na fase de crescimento para fora" (Cardoso \& Faletto, 1973: 53).

Creio ser desnecessário reproduzir todo o desdobramento da análise de Cardoso e Faletto, sobretudo porque a partir deste ponto Cardoso e Faletto enveredam por interpretações históricas circunscritas a países da América Latina que podemos recuperar na medida de nossa necessidade. Feito um reconto geral, o que resta patente é a sensibilidade às contradições e às tensões do jogo político e social que o esquema analítico de Cardoso e Faletto possui. Mais interessante ainda é quando tentamos ver a natureza mais geral, pregressa e presente, do desenvolvimento capitalista na América Latina desde este novo ângulo. A interpretação iniciada por Cardoso e Faletto, e depois continuada apenas por Cardoso, chama a atenção para o fato de que o desenvolvimento capitalista depende em larga medida das lutas sociais internas, que fazem dos tipos de relações sociais os determinantes da natureza que o desenvolvimento e a acumulação capitalistas podem adquirir no Brasil; se a CEPAL via o desenvolvimento como uma forma específica de relação entre países centrais e periféricos, os estudos sobre a dependência não dispensam este fato mas qualificam-no melhor, precisando que são as condições sociais internas que delinearão a maneira pela qual os impulsos vindo do movimento maior do sistema capitalista internacional serão recebidos. Donde se pode retirar a sugestão de que nossas possibilidades de desenvolvimento capitalista e, quem sabe, de alguma superação do subdesenvolvimento, foram e são dadas internamente - apesar de mencionado por diversas vezes, o peso das injunções externas é pouco ou nada esclarecido (esse ponto será explorado adiante). Dentro desse universo, as possibilidades de desenvolvimento abertas historicamente para um país como o Brasil fundamentam-se em formas do jogo social, em configurações políticas, que souberam aproveitar momentos especiais da vinculação brasileira com o exterior e retiraram daí dividendos econômicos e políticos para o desenho de uma dada estrutura de dominação interna, capitaneada por esta ou aquela classe e grupo social e insuflada por seus interesses (Cardoso \& Faletto: 1977: 357). 
Um exemplo desta modalidade de brechas que puderam ser relativamente aproveitadas está na interpretação que Cardoso e Faletto fazem do caso brasileiro, especialmente no período pós-Segunda Guerra Mundial, quando teria surgido espaço para nossa industrialização com o auge do processo de substituição das importações e o início da chamada "internacionalização dos mercados". Ter-se-ia dado uma articulação entre interesses nacionais e internacionais, sob a irrupção do capitalismo monopolista, que desencadeou um processo bifronte no qual, numa face, os setores burgueses industriais nacionais desancavam os agrários na hegemonia política e, noutra, os capitais internacionais encontravam nestas plagas latino-americanas novas áreas de exploração e valorização (Cardoso \& Faletto, 1973: 52-90, 91-113, especialmente 103-108). Já aí, ou desde aí, um passo em direção ao desenvolvimento capitalista brasileiro significa um passo a mais rumo ao emaranhado das redes do capital internacional, antecedência do "tripé" Estado-capital privado nacional-capital privado internacional tão imprescindível ao Brasil.

No entanto, a prudência recomenda cuidado com a interpretação dessas idéias. Entender que o desenvolvimento capitalista brasileiro - ou latino-americano, em sentido lato - seria deliberadamente amplo, franqueado de uma tal maneira que todos os limites poderiam ser ultrapassados, é carregar a mão durante a feitura da análise e considerar inoperantes as relações de dominação próprias do capitalismo em nível mundial. Na verdade, a área de manobra dos países dependentes é limitada por limites estruturais dados pelo sistema capitalista internacional. É certo que esses limites, assim como o próprio capitalismo e mesmo o caráter da dependência, vão mudando com o tempo — nada mais natural, posto serem elementos de marcado traquejo histórico e dinâmico; ocorre, todavia, que a manutenção de tais limites está atrelada à própria manutenção e à integração neste sistema, isto é, o que quero afirmar é que os limites aqui tratados são sempre repostos. Assim, o desenvolvimento capitalista em países dependentes, Brasil principalmente, é indicado por um campo dado pelo capitalismo internacional dentro do qual jogam os grupos e classes sociais internos em disputa e em defesa de seus interesses. Os próprios autores aqui em tela fazem questão de afirmar que não vêem o desenvolvimento da periferia capitalista como uma possibilidade infinita, muito pelo contrário, "a interpretação proposta considera a existência de limites estruturais precisos para um desenvolvimento industrial controlado nacionalmente, dentro do qual jogam as distintas forças sociais" 
(Cardoso \& Faletto, 1973: 118). Se essa afirmação é efetivamente levada em conta por Cardoso em seus trabalhos posteriores, é algo que será verificado adiante.

De qualquer forma, o que Cardoso e Faletto percebem e procuram sustentar é que, mais do que nunca, o sistema capitalista internacional vai-se modificando ao deixar de lado a exportação de capitais do capitalismo concorrencial e adotar o fomento de mercados internos em países dependentes mediante a "internacionalização dos mercados" (Cardoso \& Faletto, 1973: 114 e ss.) e a penetração do capitalismo monopolista. Assim, ao contrário de sua história pregressa, a América Latina passa a ver em seu próprio processo históricosocial que - esta é a nota forte destes estudos sobre a dependência — industrialização e desenvolvimento capitalistas não conflitam com monopólios e com a dependência (Cardoso \& Faletto, 1973: 122 e ss.). A esse respeito Cardoso é claro num de seus textos posteriores, ao dizer que,

\footnotetext{
"Estritamente falando (...), não será difícil mostrar que desenvolvimento e penetração de monopólio [em sociedades e economias dependentes] não são incompatíveis (...) De fato, dependência, capitalismo monopolista e desenvolvimento não são termos contraditórios, pois ocorre um tipo de desenvolvimento capitalista dependente nos setores do Terceiro Mundo que estão integrados na nova forma de expansão monopolista" (Cardoso, 1973: 195) ${ }^{15}$.
}

Ainda nesse mesma direção, mas em outro texto, Cardoso dissera que “(...) o novo caráter da dependência (depois da internacionalização do mercado interno e da nova divisão internacional do trabalho que franqueia à industrialização as economias periféricas) não colide com o desenvolvimento econômico das economias dependentes" (CARDOSO, 1975b: 57).

Ora, na passagem acima Cardoso apenas expressa o que já está em seu trabalho de 1969 com Faletto, vale dizer, que a nova etapa do capitalismo internacional abre "possibilidades estruturais" para o desenvolvimento capitalista dos países dependentes, constituindo o que eles chamam de "dependência de outra índole" (Cardoso \& Faletto, 1973: 126-127). É a chance de lograr certo desenvolvimento que, todavia, não elimina os laços de dependência, antes redefine-os. Eis o "desenvolvimento dependente-associado":

\footnotetext{
${ }^{15}$ Opinião semelhante é expressa com abundância de dados por B. Warren, porém alguns anos depois; veja Warren (1973). Já sobre os liames entre os estudos sobre a dependência e a teoria marxista do imperialismo
} 
"A partir dessa situação, poder-se-ia supor que existe simultaneamente desenvolvimento e autonomia; entretanto, se é certo que a dependência que subsiste é de outra índole (ou tem novo caráter), esse tipo de desenvolvimento continua supondo heteronomia e desenvolvimento parcial, daí ser legítimo falar de países periféricos, industrializados e dependentes" (Cardoso \& Faletto, 1973: 127).

De fato, é preciso reconhecer que países da América Latina como o Brasil não enveredaram por nenhum dos dois extremos potenciais da situação de subdesenvolvimento: ruptura com o sistema capitalista internacional (socialismo etc.) ou manutenção de uma economia primário-exportadora (neocolonialismo etc.). $\mathrm{O}$ que ocorreu foi que $\mathrm{o}$ desenvolvimento capitalista nesses países adquiriu formas (explicáveis pelas relações sociais internas, segundo o esquema de Cardoso e Faletto) que mantiveram a dependência estrutural e externa apesar da considerável industrialização, o que confirma a pouca ou nenhuma pretensão de hegemonia das burguesias nacionais brasileiras e latino-americanas. Nessa dispensa do socialismo e abraço de um "subcapitalismo", as burguesias nacionais brasileiras garantiram alguns passos à frente no desenvolvimento capitalista dependente, isto é, ativeram-se dócil e disciplinadamente às "barreiras estruturais" (Cardoso \& Faletto, 1973: 142) postas à atividade do país ${ }^{16}$.

De qualquer forma, o constructo da corrente "reformista" dos estudos sobre a dependência permanece: diferenciando-se do dual-estruturalismo, sobretudo do de Furtado, o que se pretendeu foi enfocar mais detidamente o desenvolvimento capitalista brasileiro e latino-americano, que de modo geral deixava assim de ser subdesenvolvido para ser dependente. Interessa agora mostrar e explorar o fato de que, tanto no trabalho conjunto de com Faletto quanto nos escritos posteriores, Cardoso maneja o enfoque que elaborou de uma maneira tal que desenvolvimento, subdesenvolvimento e dependência deixam de ter algum antagonismo mais forte e pronunciado - como nos trabalhos de Furtado.

(Cardoso considera aqueles complementos desta), consulte os trabalhos de Cardoso (1973: 186-209; 1993: 102).

${ }^{16}$ Veja também Cardoso \& Faletto (1977). Cardoso irá se referir a essa mesma aliança como o já citado “tripé” do desenvolvimento dependente-associado brasileiro (Cardoso, 1973; 1975a; 1993; todos passim). 


\section{Desaparecimento dos obstáculos internos e externos: sociedade nacional apesar da dependência}

Ainda que de modo bastante sucinto, o núcleo da abordagem de Cardoso a respeito do desenvolvimento capitalista dependente pôde ser razoavelmente delineado. São muitos os pontos de interesse que tal vertente dos estudos sobre a dependência desperta, porém vamos nos restringir somente a um deles: importa aqui tentar verificar o lugar que Cardoso dá à sociedade nacional em seu arcabouço teórico, isto é, seguindo a preocupação do primeiro capítulo, procurar saber se a Nação tem para Cardoso a mesma relevância que tem para Furtado e, mais, como aquele lida com a questão nacional no bojo do desenvolvimento capitalista brasileiro. Como já se disse, a suposição é a de que precisamente nesta matéria Furtado e Cardoso distanciam-se: enquanto o primeiro entende que a consolidação nacional somente é possível com a superação do subdesenvolvimento, o segundo parece crer que a construção de uma sociedade nacional pode ser feita mesmo que os laços de dependência não sejam desatados (ou por outra, a dependência não constitui empecilho algum).

Posto isso, é nas formulações sobre as possibilidades de desenvolvimento na dependência - o "desenvolvimento dependente" — que tal aspecto da questão nacional no pensamento de Cardoso expressa-se de modo mais cristalizado, de sorte que sobre elas deve recair nosso foco doravante.

Já foi dito, embora não exaustivamente, que um dos efeitos do Golpe Militar de 1964 foi lançar parte considerável do pensamento social e político brasileiro no rol das idéias e teses que sustentavam que o desenvolvimento capitalista brasileiro estaria entrando em uma fase de recessão e de estagnação. Por exemplo, para Furtado (conforme vimos no capítulo anterior), uma vez rompida a normalidade democrática, o desenvolvimento capitalista deveria regredir a níveis primário-exportadores. Mas sobretudo os trabalhos de Ruy Mauro Marini e dos de Theotônio dos Santos, representantes dos estudos "marxistas" sobre a dependência, são paradigmáticos na exploração dessa tese: grosso modo, segundo esses autores o capitalismo brasileiro teria atingido o seu limite histórico e caminhava para a estagnação, para o que havia duas alternativas somente: do lado das elites, a manutenção do status quo capitalista através do recurso ao "fascismo" (do que a ditadura militar 
brasileira seria uma expressão) e, do lado da população em geral, a ruptura completa do processo histórico-social brasileiro através de uma revolução socialista. Sem isso, somente a estagnação ${ }^{17}$. Ou seja, nesses casos todos, enfatiza-se mais os limites que as possibilidades de desenvolvimento brasileiro; nesse sentido, os escritos assumem tons ora pessimistas ora radicais, posto que não haveria saída possível se não a ruptura e a revolução. Assim foi com esses teóricos da dependência.

Não, entretanto, com Cardoso, apesar de ele também teorizar sobre a dependência. A concordância de Cardoso com Marini e Dos Santos a respeito do caráter dependente do desenvolvimento capitalista brasileiro não o levou a enveredar pelo mesmo caminho que eles e a negar possibilidades de novas fases de crescimento e desenvolvimento. Pelo contrário, são as possibilidades do desenvolvimento capitalista brasileiro ainda que no bojo da dependência que Cardoso mais enfatiza em seus escritos, ênfase que ganha destaque porque sempre em debate aberto com as idéias dos "estagnacionistas", reputadas como incorretas e equivocadas. Aliás, é preciso dizer que a ênfase de Cardoso nas possibilidades de desenvolvimento apesar da dependência é uma constante em seus trabalhos. O que já estava implícito em primeiros escritos (por exemplo, Cardoso, 1964) foi depois paulatinamente ganhando evidência. A esse respeito, no prefácio de seu livro com Faletto (Dependência e desenvolvimento na América Latina) está que o objetivo daquele trabalho "é esclarecer alguns pontos controvertidos sobre as condições, possibilidades e formas do desenvolvimento econômico em países que mantêm relações de dependência com os pólos hegemônicos do sistema capitalista (...)" (Cardoso \& Faletto, 1973: 07). Ou seja, além do que já foi reportado, o livro de Cardoso e Faletto tem a pretensão de estabelecer que, nalguns casos, é sim factível a ocorrência de desenvolvimento na dependência, e assim o fazem, como exposto em passagem citada na final do item anterior (Cardoso \& Faletto, 1973: 127). De maneira análoga, a idéia é reafirmada na conclusão:

\footnotetext{
"A novidade da hipótese [do referido ensaio] não está no reconhecimento da existência de uma dominação externa — processo óbvio — mas na caracterização da forma que ela assume e dos efeitos distintos, com referência às situações passadas, desse tipo de relação de dependência sobre as classes e o Estado. Salientamos que a situação atual de desenvolvimento dependente não só supera a
}

\footnotetext{
${ }^{17}$ Marini (1969, 1972 e 1979); Dos Santos (1969a, 1969b, 1969c, 1970 e 1977). Dos Santos (1969a: 11) escreve: “(...) a crise do atual modelo de desenvolvimento latino-americano, caracterizado como um desenvolvimento capitalista dependente, conduzirá inevitavelmente na América Latina e particularmente no Brasil a uma alternativa inescapável entre socialismo ou fascismo" (os itálicos não estão no original).
} 
oposição tradicional entre os termos desenvolvimento e dependência, permitindo incrementar o desenvolvimento e manter, redefinindo-os, os laços de dependência, como se apoia politicamente em um sistema de alianças distintos daquele que no passado assegurava a hegemonia externa" (Cardoso \& Faletto, 1973: 141, negritos meus).

Percebamos que já no trabalho inaugural dos estudos sobre a dependência em sua vertente reformista está algo que depois será ratificado repetidas vezes por Cardoso, isto é, que a disjuntiva muito forte para Furtado entre desenvolvimento, subdesenvolvimento e dependência é, como o reconhece o próprio Cardoso, simplesmente desmontada. Ora, ao se referir a uma modalidade de "desenvolvimento dependente" Cardoso junta dois termos que no pensamento cepalino-furtadiano seriam inconciliáveis e, mais ainda, faz isso não para acentuar o segundo termo, o "dependente", mas para frisar o primeiro, o “desenvolvimento”. Por si só essa distinção já seria notável e muito significativa, mas ela o é mais ainda pelo que denota a respeito da questão nacional — do lugar da Nação no pensamento de Cardoso. Embora ele (ou melhor, ele e Faletto) deixe claro no prefácio que a preocupação primordial de seu ensaio é com países que se constituíram em Nações e organizaram Estados nacionais, ainda assim a dependência não é, no mais das vezes, fator impeditivo à consolidação das sociedades nacionais; por outro lado, o processo de constituição da Nação não implica no questionamento da estrutura do sistema capitalista internacional. O pensamento de Furtado portava uma radicalidade muito própria, derivada de sua compreensão do fenômeno do subdesenvolvimento; em Cardoso, o que se pode derivar é que a aceitação de uma posição subordinada para a sociedade nacional no sistema capitalista internacional não é algo totalmente prejudicial para seu desenvolvimento capitalista - diferença significativa e que parece estar contida no fato de "dependência" ser uma noção bem menos delimitada que "subdesenvolvimento" (voltaremos a esse assunto adiante). Embora Cardoso procure matizar sua abordagem, indicando vez por outra que há limites ao desenvolvimento capitalista brasileiro, o que podemos sintetizar de tais análises é que, ao fim e ao cabo, o desenvolvimento capitalista brasileiro perde sua especificidade e, no limite, surge como que franqueado à vontade nacional, a depender apenas dos corretos arranjos políticos internos. E o lugar da Nação no sistema capitalista internacional, esse não é questionado de modo sistemático como em Furtado.

De qualquer forma, a perspectiva de Cardoso mostra-se com mais nitidez quando ele tece críticas aos trabalhos do outro ramo dos estudos sobre a dependência, o "marxista". 
Contra uma abordagem que enfatiza que somente com a dissolução dos laços de dependência seria possível a um país como o Brasil lograr um efetivo desenvolvimento, Cardoso está a afirmar o tempo todo que o capitalismo lança mão de novos mecanismos para levar adiante sua acumulação na periferia, com o que brechas poderiam se abrir para o desenvolvimento capitalista brasileiro. As considerações que daí podemos retirar são bastante elucidativas para o que quero indicar nesse capítulo da dissertação.

Invocando para si o papel de defensor da "boa" dialética, das interpretações nãodogmáticas e respeitadoras da "historicidade das estruturas", do espírito dinâmico e "aberto" da história e das contradições inerentes ao capitalismo (por exemplo, Cardoso, 1974; 1975a; 1993: 95 e ss.), Cardoso volta-se contra as idéias e as teses da vertente marxista dos estudos sobre a dependência, que sofreriam de uma profunda incompreensão do caráter "progressivo" do capitalismo - e que por isso advogariam a estagnação do desenvolvimento capitalista brasileiro (daí a pecha de "estagnacionistas"). Por exemplo, Cardoso arremete contra a tese de Marini sobre a "superexploração do trabalho", pela qual os países periféricos tinham forçosamente que intensificar a exploração do trabalho (superexplorá-lo) a fim de compensar a transferência de mais-valia daqui para os países capitalistas centrais (Marini, 1979: 38 e ss.) ${ }^{18}$; o resultado seria a realimentação da dependência e a manutenção do subdesenvolvimento brasileiro. Ora, Cardoso discorda desta tese dizendo que, ao contrário do que a corrente marxista sustenta, a "nova forma de dependência" não assenta sobre a exploração da mais-valia absoluta, mas sim sobre a maisvalia relativa (Cardoso, 1993: 105), uma vez que o capitalismo dependente seria capaz de gerar novas formas de exploração e de relações de produção que dispensariam — ou ao menos relegariam-na à posição de instrumento ocasional — a mais-valia absoluta e servirse-iam da relativa. Reconhecer isso, diz Cardoso, é reconhecer que o capitalismo "industrial" é um processo constante de superação e de dinamização das relações de produção (o progresso tecnológico e o aumento da produtividade do trabalho).

\footnotetext{
18 "As classes dominantes locais tratam de ressarcir-se desta perda aumentando o valor absoluto da mais-valia criada pelos trabalhadores agrícolas ou mineiros, isto é, submetendo-os a um processo de superexploração. A superexploração do trabalho constitui assim o princípio fundamental da economia subdesenvolvida, com tudo o que implica em matéria de baixos salários, falta de oportunidades de emprego, analfabetismo, subnutrição e repressão policial” (Marini, 1969: 08-09).
} 
"Esquecem-se os que se apegam a este estilo de interpretação que o capital, se bem expresse diretamente uma relação social de exploração, implica, quando o capitalismo avança, tanto o uso de tecnologias como a produção de excedentes que dão vida e dinamismo a setores não produtivos da sociedade. E se esquecem também que o nervo do capitalismo avançado baseia-se na extração da mais-valia relativa (decorrente do progresso técnico e não da superexploração da jornada de trabalho) e na competição (embora oligopólica) entre produtores” (Cardoso, 1975a: 14).

Assim, os teóricos da vertente marxista dos estudos sobre a dependência não teriam entendido o traquejo capitalista e, em vista disso, teriam generalizado infinitamente o processo da acumulação primitiva do capitalismo, esta sim impulsionada pela mais-valia absoluta; em suma, careceriam de uma visão mais dialética e menos estática do capitalismo para perceber que outras modalidades de exploração foram engendradas historicamente, e que justamente estas seriam o impulso, e não obstáculo, do desenvolvimento capitalista, sobretudo nessa fase monopólica (Cardoso, 1993: 109).

\begin{abstract}
"Assim, não dialetizando-se [sic] a análise, transforma-se uma fase do ciclo expansivo ou uma etapa da acumulação em condição 'necessária' da etapa seguinte, e perde-se a especificidade do que é novo no processo social. (...) a especificidade da etapa de 'internacionalização do mercado interno' está justamente na emergência dos setores oligopólicos e não na generalização da exploração baseada na mais-valia absoluta" (Cardoso, 1975a: 32-33).
\end{abstract}

Com efeito, nosso interesse nessa discussão passa ao largo de saber se o desenvolvimento capitalista brasileiro e latino-americano dá-se pela mais-valia absoluta ou relativa; mais importante que isso é perceber que, reprovando o raciocínio de Marini e também o de Dos Santos, que estariam negando o "caráter positivo" do desenvolvimento capitalista na periferia e da possibilidade de haver desenvolvimento $e$ dependência $a$ um só tempo (Cardoso, 1993: 106 e 106-107), Cardoso expressa claramente que o caminho do desenvolvimento capitalista brasileiro não é apenas o da superação da dependência; além do mais, dizendo que desenvolvimento capitalista não implica necessariamente em superação do subdesenvolvimento ${ }^{19}$, ele patenteia que, ao contrário do que pensa Furtado, a construção e o fortalecimento da sociedade nacional e seu lugar no sistema capitalista

\footnotetext{
19 "Por certo, quando se pensa que o desenvolvimento capitalista supõe redistribuição de renda, homogeneidade regional, harmonia e equilíbrio entre os vários ramos produtivos, a idéia de que está ocorrendo um processo real de desenvolvimento econômico na periferia dependente (ou melhor, nos países da periferia que se industrializaram, pois não é possível generalizar o fenômeno) parece absurda. Mas não é este o entendimento marxista sobre o que seja desenvolvimento (ou acumulação) capitalista. Esta é contraditória, espoliativa e geradora de desigualdades" (Cardoso, 1993: 106). Noutro lugar nosso autor é ainda mais incisivo ao dizer que "só os ingênuos confundem desenvolvimento capitalista com melhoria geral e igualitária do nível de vida" (1975a: 16).
} 
internacional pouco importa nesse processo. De fato, esse é o entendimento de Cardoso. Por isso é que, segundo ele mesmo, nem Marini nem Dos Santos teriam se dado conta, quer teórica, quer praticamente, do que ocorria nas economias de países como Brasil e México nos anos 1960 e parte dos 1970, isto é, eles não teriam se dado conta da ocorrência de desenvolvimento capitalista ${ }^{20}$.

Munido de uma "análise integrada" do desenvolvimento capitalista na periferia, Cardoso defende que é preciso compreender o movimento capitalista em toda a sua dinâmica, isto é, atentando para as novas formas de dependência e os novos mecanismos de que se serve o sistema capitalista internacional para a consecução de sua acumulação. Nesse sentido, os estudos sobre a dependência deveriam, segundo Cardoso, se de fato queriam expressar a realidade, tentar esmiuçar as maneiras pelas quais o capitalismo internacional modifica sua relação com a periferia e passa a localizar seus interesses no desenvolvimento capitalista desta e não mais na manutenção de seu estatuto periférico. Como Cardoso mesmo sustenta, semelhante expediente leva-o a ressaltar o "papel progressista" do capitalismo na periferia - ao desenvolver as forças produtivas e dinamizar as relações de produção — contra a posição "negativa" da corrente marxista, numa espécie de reedição tropical da polêmica entre Lênin e os populistas russos, como o ventila o próprio Cardoso, que faria as vezes do líder comunista (Cardoso, 1975a: 27-28; 1993: 110). Sendo assim, para Cardoso idéias, teses e categorias como "superexploração do trabalho", "subimperialismo", a disjuntiva "socialismo ou fascismo" etc. somente empanariam, a despeito da boa intenção, a compreensão do "capitalismo industrial", já francamente espraiado pelo Brasil (Cardoso, 1975a: 39 e ss. e 131 e ss.; 1993: 136 e ss.). Sem mais circunlóquios, pode-se perfeitamente dizer que, ressalvado que a polêmica não se restringe somente a isso, enquanto os "marxistas" põem o acento de suas análises nos limites do desenvolvimento capitalista por conta da dependência, Cardoso difere e acentua as possibilidades do desenvolvimento não obstante a dependência.

\footnotetext{
20 "Nestes termos, não vejo como recusar o fato de que a economia brasileira ou a mexicana estejam desenvolvendo-se capitalisticamente. Nem se alegue que existe apenas um processo de 'crescimento', sem alterações estruturais. A composição das forças produtivas, a alocação de fatores de produção, a distribuição da mão-de-obra, as relações de classe, estão se modificando no sentido de responder mais adequadamente a uma estrutura capitalista de produção" (Cardoso, 1993: 106).
} 
“A razão pelo qual trato de limitar o alcance teórico das explicações dadas por Marini (sem negar o peso histórico de alguns de seus argumentos) diz respeito à própria teoria marxista do capitalismo e ao ponto anteriormente mencionado relativo à compatibilidade entre dependência e desenvolvimento capitalista. Com efeito, parece-me que na ótica marxista as condições gerais da acumulação (ou seja, a exploração absoluta do trabalho) combinam-se com as específicas (a diminuição do período de trabalho necessário em proveito do trabalho excedente e a potenciação das forças produtivas) e tem nestas últimas o traço distintivo. Atribuir o caráter de necessidade ao processo de exploração irrefreado da força de trabalho da periferia do sistema (convém dizer que Marini não afirma categoricamente isto) para a acumulação nas economias centrais leva a descaracterizar a especificidade do capitalismo industrial" (Cardoso, 1993: 110). ${ }^{21}$

Uma outra rodada dessas críticas está na polêmica disparada por um texto no qual Cardoso e José Serra criticam as idéias de Marini, sobretudo seu livro Dialéctica de la dependencia $^{22}$. Aí fica igualmente evidente o que vem sendo dito, que Cardoso dá peso considerável (exagerado, veremos) às possibilidades de desenvolvimento, aspecto de interesse central para este capítulo da dissertação. À parte a pretensão que há em esclarecer equívocos de uma interpretação do desenvolvimento capitalista dependente que daria margem e inspiração a aventuras políticas incertas e mesmo fatais, interessa ressaltar aí o mesmo diapasão das críticas anteriores, quer dizer, para Serra e Cardoso Marini não compreende o traquejo do desenvolvimento capitalista dependente. Curiosamente, voltam

\footnotetext{
${ }^{21}$ Apenas para constar, posto que não é objetivo desta dissertação analisar em si as contribuições dos estudos sobre a dependência segundo a vertente marxista, convém mencionar que, respondendo às críticas a sua idéia de "superexploração do trabalho", Marini diz (numa espécie de post-scriptum a Dialéctica de la dependencia) que “(...) o conceito de superexploração não é idêntico ao de mais-valia absoluta, já que inclui também uma modalidade de produção de mais-valia relativa — que corresponde ao aumento da intensidade do trabalho", e que "O que se discute é se as formas de exploração que se distanciam da que engendra a mais-valia relativa sobre a base de uma maior produtividade devem ser excluídas da análise teórica do modo de produção capitalista. O equívoco de Cardoso está em responder afirmativamente a esta questão, como se as formas superiores da acumulação capitalista implicassem a exclusão de suas formas inferiores e se dessem independentemente destas. Se Marx tivesse compartido dessa opinião, seguramente não havia se preocupado com mais-valia absoluta e não a havia integrado, enquanto conceito básico, em seu esquema teórico" (Marini, 1979: 93). Por sua parte, em escrito mais recente em que se refere às polêmicas entre "marxistas" e "reformistas" no campo da dependência, Dos Santos afirma: "O que nos separava da outra corrente não era a constatação dessas possibilidades de avanço democrático, mas sim a tese de que essas possibilidades de avanço democrático sejam compatíveis com a sobrevivência de um capitalismo dependente. É exatamente este o ponto de divergência, posto que a minha visão é de que a acumulação e o avanço democrático desestabilizará crescentemente o capitalismo dependente na região e aumentará a contradição entre esse movimento democrático e a sobrevivência do capitalismo dependente" (Santos, 1994: 54).

${ }^{22}$ Os textos de Serra e Cardoso e a resposta de Marini saíram publicados ao mesmo tempo em número extraordinário da Revista Mexicana de Sociología (1978). Por justiça, creio ser relevante observar que tanto Mantega (1995) quanto Goldenstein (1994) fazem menção apenas ao escrito de Serra e Cardoso (1978), não à resposta de Marini (1978). Nesse sentido, talvez uma afirmação como a de Goldenstein, de que "Serra e Cardoso fazem uma crítica arrasadora e definitiva às posições de Marini” (Goldenstein, 1994: 34, grifo meu), deva ser relativizada, visto que, ainda que arrasadora (o que é fato), a crítica só é "definitiva" para quem desconhece a réplica de Marini. Quiçá a inclusão das considerações de Marini não alterasse substancialmente as apreciações de Mantega e de Goldenstein, mas seria adequado ao menos mencioná-la.
} 
contra Marini os mesmos reparos que foram feitos ao pensamento cepalino-furtadiano, isto é, acusações de economicismo: querendo entender o fenômeno da dependência, Marini teria sufocado o principal, que seria a dinâmica das classes, com seu economicismo e com sua ênfase na determinação mecânica do exterior sobre o interior. Ou seja, a política estaria reduzida a mero reflexo da economia (Serra \& Cardoso, 1978: 11), de tal sorte Marini

\begin{abstract}
"elude o que é básico: a dinâmica que deriva da luta entre as classes. Esta, por certo, se desenvolve a partir de contradições sociais e econômicas (que não são apontadas por Marini). Mas é o jogo político que faz mover em uma ou outra direção os parâmetros econômicos dentro dos quais se desenvolvem as lutas entre as classes. O reducionismo economicista que faz repousar a impossibilidade da expansão capitalista da periferia em limites estruturais do tipo dos assinalados por Marini, ademais de ser, como vimos, falsos teoricamente, mata o nervo da análise política, levando-a a basear-se em um catastrofismo que não se cumpre” (Serra \& Cardoso, 1978: 27).
\end{abstract}

Assim seria a análise de Marini segundo o entendimento de Serra e Cardoso. Para estes, ao descaracterizar as possibilidades históricas de mediações, impasses, contradições, lutas e transformações, Marini congelaria instantes de crise da economia brasileira e os elevaria à categoria de leis gerais, daí sua supervalorização dos limites do desenvolvimento capitalista brasileiro, limites esses que somente seria rompidos quando os trabalhadores, de súbito, irrompessem na esfera política ${ }^{23}$. Note-se que, mesmo que feitos a Marini, tais críticas podem ser perfeitamente estendidas aos outros autores da corrente marxista dos estudos sobre a dependência (Dos Santos sobretudo) ${ }^{24}$.

De tudo isso resta pois que o mote geral dos reparos que Cardoso remete aos teóricos marxistas assenta na incompreensão da especificidade do capitalismo industrial num país periférico como o Brasil. Ora, mas o que afinal os teóricos marxistas não teriam compreendido? Segundo Cardoso, eles não teriam percebido que o capitalismo estava em nova fase, na qual a antiga dicotomia entre desenvolvimento e dependência ou entre desenvolvimento e subdesenvolvimento dava lugar a laços mais articulados entre os países centrais e os periféricos: os primeiros não mais se opunham, como antes, à industrialização e ao crescimento dos segundos. Nesse sentido, não haveria por que apostar que o

\footnotetext{
${ }^{23}$ Nas palavras de Serra e Cardoso, Marini, confundindo-se no amplo mundo dos conceitos marxistas "mostrou, melhor que ninguém, que sua análise, de aparência dialética, em realidade pratica um ímpio reducionismo econômico que, ao projetar cone de sombra sobre as alternativas históricas e as opções políticas em cada conjuntura, instaura a primazia do economicismo e do voluntarismo" (Serra \& Cardoso, 1978: 51).

${ }^{24}$ Considerações mais apuradas sobre os trabalhos de Marini e Dos Santos podem ser encontradas em Fausto (1971), Palma (1987: 50-59) e Mantega (1995: 261-281).
} 
desenvolvimento capitalista brasileiro seria obstado pela estagnação quando, pelo contrário, podia se esperar novas possibilidades de desenvolvimento.

Posto isso, volto a assinalar que, para além das qualidades e dos interesses teóricos que carregam consigo (e são vários), os debates entre "reformistas" e "marxistas", valem pelo que revelam do modo como Cardoso vê a questão da Nação no desenvolvimento capitalista brasileiro. Creio que nas teorizações de Cardoso - desde seu trabalho em conjunto com Faletto até os posteriores, que vimos - fica razoavelmente patente sua dissociação do pensamento cepalino-furtadiano. Como tive oportunidade de dizer, há entre o esquema interpretativo de Furtado (paralelamente ao da Cepal) e o de Cardoso continuidades e rupturas; no que foi exposto está presente uma dessas rupturas, quiçá a mais relevante: em Cardoso a questão nacional - o lugar e a importância da sociedade nacional - perde a centralidade que tinha em Furtado. Para expressar isso em termos apropriados, Cardoso desfaz o elo que ligava, no pensamento cepalino-furtadiano, diferenciação do sistema econômico e formação de centros internos de decisão; em seu raciocínio, a "dependência de outra índole", operada pelo sistema capitalista internacional e que anima agora o desenvolvimento capitalista brasileiro, permite que o sistema econômico assuma outros contornos, diferenciando-se, sem que os centros de decisões sejam internalizados, isto é, tal sistema econômico periférico pode se desenvolver mesmo que as decisões a respeito do que fazer e como utilizar o capital acumulado não partam da sociedade nacional, mas de fora (vale dizer, perpetuando os laços de dependência externa e estrutural). Isso não é nada mais que aquilo que Cardoso reiteradamente sustentou em seus trabalhos afirmando que, na nova quadra da "internacionalização dos mercados" (Cardoso \& Faletto, 1973), o desenvolvimento capitalista pode se dar mesmo no bojo da dependência, que esta não impede aquele (como os reproches dirigidos a Marini e a Dos Santos sintetizam).

Com efeito, assim procedendo Cardoso distancia-se grandemente de Furtado e, de quebra, marca sua distinção em relação ao formalismo das análises dos teóricos "marxistas" da dependência. Com Furtado, e isso é o que mais importa apontar aqui, o distanciamento faz-se porque o desenvolvimento capitalista periférico não mais necessitaria obrigatoriamente da formação de centros internos de decisão (que em Furtado significa a submissão das diretrizes do desenvolvimento aos ditames da sociedade nacional, e não a 
uma parcela dela somente); com os "marxistas", porque o desenvolvimento capitalista prescinde da ruptura da dependência por intermédio de uma revolução socialista. De novo, desenvolvimento com (ou $n a$ ) dependência. Note-se que não digo que Cardoso simplesmente não leva em conta a questão do Estado Nacional: fazê-lo seria uma impropriedade, se não porque desde o início ele estabeleceu que seu interesse maior seria os países que lograram formar Estados Nacionais ${ }^{25}$, porque a própria noção de dependência exige a instituição do Estado Nacional formalmente soberano (não fosse assim, com a existência de um Estado fazendo a intermediação entre os interesses internos e externos, teríamos outra situação, menos a dependência aqui tratada). Meu ponto é outro: digo que em Cardoso qualquer que seja o encaminhamento dado ao problema do desenvolvimento capitalista dependente pouco ou nada muda na questão da sociedade nacional. O desenvolvimento que é possível lograr não influi na posição no processo de consolidação da sociedade nacional na inserção desta no sistema capitalista internacional: o que se deduz das teorizações de Cardoso é que se pode alcançar algum desenvolvimento capitalista sem que a condição subordinada e dependente do país (do Estado Nacional) na ciranda do capitalismo internacional seja posta em discussão.

Deste ponto de vista é que a distinção ante Furtado torna-se mais visível. Se, como vimos, em Furtado a defesa da Nação faz com que seu esquema interpretativo converta-se numa teoria da superação necessária do subdesenvolvimento, as idéias de Cardoso podem muito bem serem lidas como uma espécie de teoria da "acomodação subordinada" da Nação ao sistema capitalista internacional. Como se vê, buscando aprimorar o pensamento dual-estruturalista através de uma interpretação dialética do desenvolvimento capitalista brasileiro, que fosse sensível aos tortuosos trajetos da história (que é extremamente salutar, deve-se reconhecer sem favor algum), Cardoso prejudica um dos pontos fortes do arcabouço furtadiano, que é exatamente a radicalidade em relação à configuração do sistema capitalista internacional e à especificidade brasileira ali dentro. Daí que o desenvolvimento capitalista possa aparecer ali como livremente franqueado ao Brasil, sem obstáculos.

Entendida a interpretação de Cardoso desde esta perspectiva, a oscilação teórica entre classe e Nação que F. Weffort aponta nos estudos sobre a dependência em geral, mas

\footnotetext{
${ }^{25}$ Basta ver o "Prefácio" de Dependência e desenvolvimento na América Latina.
} 
especificamente nos de Cardoso, pode ser tomada como desdobramento ou índice do que foi dito acima. Para Weffort, haveria nesses estudos uma oscilação ou uma ambigüidade de nascença entre uma análise baseada no conceito de "classe" e outra baseada no de "Nação", de modo que não fica claro se o que deve preponderar na noção de dependência é a "classe" ou a "Nação" (Weffort, 1971: 08-10): é à classes sociais e a seus jogos políticos que a atenção é chamada nesses estudos, mas eles não teriam conseguido se desvencilhar integralmente da idéia de uma dependência operante entre Nações. Como Weffort mesmo sustenta,

\begin{abstract}
"A imprecisão da noção de dependência, em qualquer das acepções mencionadas, está em que ela oscila, irremediavelmente do ponto de vista teórico, entre um approach nacional e um approach de classe. No primeiro, o conceito de Nação opera como uma premissa de toda a análise posterior das classes e relações de produção; ou seja, a atribuição de um caráter nacional (real, possível ou desejável) à economia e à estrutura de classes, joga um papel decisivo na análise. (...) No segundo, pretende-se que a dinâmica das relações de produção e das relações de classe determine, em última instância, o caráter (real) do 'problema nacional'.(...) Os teóricos da dependência, segundo me parece, tendem para o segundo approach, mas partem do primeiro." (Weffort, 1971: 10).
\end{abstract}

Assim, entre classe e Nação, Weffort crê que não fica esclarecido se essa ambigüidade é real (se é parte constitutiva da história) ou se é apenas um problema conceitual (Weffort, 1971: 13). A suposição dele é que se trata de uma ambigüidade conceitual, cuja resolução somente pode ser feita se se optar, decididamente, por uma abordagem de classe, no que a Nação deixa de atuar seja como premissa seja como princípio explicativo

\footnotetext{
"Pretendo sugerir que se faz necessária uma opção para um approach que, ao contrário de desconsiderar a 'questão nacional', trate de equacioná-la em termos rigorosos. Na minha opinião, a ambigüidade Classe-Nação, presente na 'teoria da dependência', deverá resolver-se em termos de uma perspectiva de classe, para a qual nem existe uma 'questão nacional' em geral (ou dependência em geral) no sistema capitalista, nem a Nação é concebida como um princípio teórico explicativo" (Weffort, 1971: 13-14).
}

Ora, esclareça-se que não discuto aqui se a saída oferecida por Weffort é pertinente ou não, se tem fundamento ou não. As observações de Weffort interessam porque, apontando dita ambigüidade, denotam que, se Cardoso não vai a fundo na análise de classes, tampouco dá à Nação o mesmo estatuto que lhe dava o pensamento cepalinofurtadiano. Ou seja, deixou de seguir o dual-estruturalismo mas não se tornou um rigoroso 
analista das classes sociais: a oscilação assinalada revela que Cardoso não é nem uma coisa nem outra. Pois bem, Cardoso mantém em seu esquema analítico a idéia de Nação, porém não com a mesma radicalidade que Furtado — talvez perdida ao tentar fazer uma análise de classes. Daí, penso, deriva a oscilação ou ambigüidade acusada por Weffort. Em resumo, a crítica de Weffort de que Cardoso mantém a Nação como premissa é aceitável, desde que, porém, frise-se que esta manutenção se faz sem a radicalidade furtadiana ${ }^{26}$.

Além do mais, essa perspectiva de "acomodação subordinada" da sociedade nacional ao sistema capitalista internacional não se faria sem um outro desdobramento dos estudos sobre a dependência de Cardoso, do qual é devedora. Se não, vejamos.

Vimos que Cardoso continuamente chama a atenção para a "análise integrada" que julga necessário fazer (e ele supõe fazer) para o devido descortino do desenvolvimento capitalista dependente - integrada porque abordaria, numa mão, política e economia a um só tempo, e, noutra mão, os âmbitos externo e interno conjuntamente, suprindo assim as questões deixadas em aberto pelo pensamento cepalino-furtadiano e evitando os equívocos da vertente marxista dos estudos sobre a dependência. Já em seu ensaio de 1969, Cardoso havia dito, junto com Faletto, que o conceito de dependência era valioso justamente por expressar o "modo de conexão" entre elementos externos e internos, mas no qual o externo "expressa-se também como um modo particular de relação entre grupos e classes sociais no âmbito das nações subdesenvolvidas" (Cardoso \& Faletto, 1973: 23). Assim, "análises concretas de situações de dependência" seriam o meio de captar essa intermediação e conexão, sem divisões estanques.

\footnotetext{
"Está claro que o suposto teórico mais geral que torna possível este enfoque é o de não existe a distinção metafísica entre os condicionantes externos e os internos. Noutros termos: a dinâmica interna dos países dependentes é um aspecto particular da dinâmica mais geral do mundo capitalista (...) Essa "unidade dialética" é que leva a recusar a distinção metafísica (isto é, que supõe uma separação estática) entre fatores externos e efeitos internos, e por consequiência leva a recusar todo tipo de análise da dependência que se baseia nesta perspectiva" (Cardoso, 1971: 30).
}

\footnotetext{
${ }^{26}$ Acrescente-se que a resposta de Cardoso, apesar de interessante por reafirmar suas premissas centrais, insiste em que o diferencial de sua análise está justamente em captar as mediações entre classe e Nação - e não em privilegiar uma ou outra instância. "Precisamente, o que se pretendeu foi mostrar que concretamente, isto é, sem apelar para as contradições gerais e indeterminadas das idéias abstratas de classe, Nação, Estado ou Imperialismo, a contradição entre as classes, nos países dependentes, passa por uma contradição nacional e se insere no contexto mais geral de uma contradição de classes no plano internacional e pelas contradições que derivam da existência de Estados Nacionais" (Cardoso, 1971: 34). O mesmo texto está reproduzido em Cardoso (1973: 123-139).
} 
Ou seja, externo e interno devem ser tomados conjuntamente. Contudo, a Cardoso interessa ressaltar o peso da política e dos conflitos internos entre classes sociais; assim é que o modo concreto pelo qual o capitalismo se expressa nos países dependentes é função "dos interesses locais, de classes, do Estado, dos recursos naturais etc. e da forma como eles se foram constituindo articulando historicamente" (Cardoso, 1971: 30-31). De modo que, e isso é o que precisa restar esclarecido, o desenvolvimento capitalista dependente é entendido como determinado em primeira instância pelo jogo político interno e, em última instância, pelo movimento mais geral do capitalismo em escala internacional ${ }^{27}$.

Tudo isso é muito interessante e, de fato, representa uma abordagem do desenvolvimento capitalista dependente, brasileiro e latino-americano, que oxigena os moldes nos quais as análises vinham sendo feitas até então. Quanto a isso não há como negar a relevância e o avanço das teorizações de Cardoso. Entretanto, bem reparada, a proposta de Cardoso parece ter exagerado na dose ao pôr em destaque o peso dos jogos políticos internos na definição dos rumos do desenvolvimento nacional: tal procedimento acaba por permitir-nos a dedução de que o sucesso ou não do desenvolvimento capitalista depende dos arranjos políticos internos adequados, das alianças bem acertadas e dos interesses de diferentes classes concertados em torno de objetivos mútuos. Nesse sentido, enfatizando o peso do âmbito interno, Cardoso parece ter perdido a dimensão e a envergadura dos condicionantes externos - positivos e negativos - do desenvolvimento capitalista nacional: daí esse desenvolvimento assumir ares de possibilidade ilimitada, a depender apenas dos jogos políticos internos; daí também a sociedade nacional poder ser pensada na chave da (inúmeras vezes mencionada) "acomodação subordinada" ao sistema capitalista internacional. Preocupado em não recorrer a interpretações formalistas da ação do externo sobre o interno ou que transformam o imperialismo numa enteléquia, Cardoso terminou por obscurecer a dominação e o antagonismo do capitalismo internacional. Noutras palavras, bem populares, Cardoso jogou a criança fora com a água do banho.

\footnotetext{
“Apesar dos avanços teóricos e das críticas à Cepal, Cardoso e Faletto acabaram caindo em uma armadilha com sua conclusão um tanto quanto otimista. A possibilidade de uma integração dinâmica com os países centrais abriria o caminho para um desenvolvimento cuja única barreira possível seria de natureza política. As 'condições econômicas' estariam dadas. (...) Ao alçar a luta de classes à
}

\footnotetext{
${ }^{27}$ Cardoso sustenta tal idéia ao aceitar reparos feitos aos estudos sobre a dependência por J. Quartim de Moraes, que é citado textualmente (Cardoso, 1975b: 51-52; a mesma passagem está em Cardoso, 1993: 101).
} 
condição de fórum precípuo no qual as estruturas seriam definidas e, ao mesmo tempo, transformadas, Cardoso e Faletto criticaram corretamente as concepções baseadas numa 'lógica inelutável do capitalismo', porém perderam de vista uma análise do movimento geral do capital internacional. No Brasil, o condicionamento deste tem se revelado mais geral e abstrato do que supunham, como conseqüência mesmo dos rumos tomados pela luta de classes". (Goldenstein, 1994: 51-52).

Vê-se pois que é essa visão otimista do capitalismo que informa a idéia do "desenvolvimento dependente", da possibilidade de desenvolvimento no bojo da dependência, como se essa fosse sequer um empecilho ${ }^{28}$. E as tenazes do sistema capitalista internacional, essas são como que entendidas como um caloroso abraço amigável. É de se notar que alguns críticos, dentre eles Marini sobretudo, já haviam anotado esse aspecto da produção de Cardoso; quando de sua polêmica com Serra e Cardoso, Marini sustentara que a recusa dos dois intelectuais em aceitar que a extração da mais-valia absoluta em países dependentes ainda pudesse interessar ao capitalismo monopolista indicava, primeiro, que eles não atentavam para a aplicação específica das leis gerais do capitalismo e, depois, que por trás dessa negação havia a suposição a priori de que "o capitalismo, à medida que se aproxima de seu modelo puro, converte-se em um sistema cada vez menos explorador e [que logra] reunir as condições para solucionar indefinidamente suas contradições internas" (Marini, 1979: 98) ${ }^{29}$.

Ademais, resta dizer que essa desconsideração dos condicionamentos externos do desenvolvimento capitalista dependente leva também à perda de um dos principais achados do pensamento furtadiano, que é a especificidade do desenvolvimento capitalista brasileiro. Embora Cardoso insista diversas vezes (em vários de seus textos) que o desenvolvimento capitalista brasileiro não é uma reprodução retardada da démarche dos países centrais, ele acaba por descaracterizar tal especificidade e embaralhar as distinções qualitativas entre o centro e a periferia capitalistas, retornando assim às teses outrora criticadas. Primeiro porque, olhando com olhos furtadianos, Cardoso chama de desenvolvimento capitalista crescimento econômico, ampliação das relações capitalistas de produção etc. — o que Furtado classificaria como processo apenas de industrialização ou de "modernização"

\footnotetext{
${ }^{28}$ Referindo ao livro de Cardoso e Faletto, Sampaio Jr. (1997: 35) escreve: "Eliminada a urgência de superar a dependência externa, o destino das sociedade periféricas passava a depender de estratégias de associação com o capital internacional que estimulassem a entrada de investimento estrangeiros, na suposição de que o avanço da acumulação capitalista asseguraria o sucesso da industrialização e de que a industrialização era o próprio desenvolvimento".

${ }^{29}$ Veja também Marini, 1979: 99-100.
} 
(posto que não estão implicados aí a melhoria do bem-estar geral da população). Mas principalmente porque, estando o desenvolvimento capitalista franqueado, bastaria apenas executar os passos corretos e as etapas necessárias para que nos tornássemos enfim desenvolvidos. Ora, se é assim, onde está a especificidade do desenvolvimento capitalista brasileiro?

\begin{abstract}
"A mudança fundamental [implementada por Cardoso e Faletto] no modo de interpretar o grau de autonomia relativa das economias satélites no sistema capitalista mundial decorre do suposto de que, dentro do raio de possibilidade aberto pelo contexto externo, o sentido, o ritmo e a intensidade das transformações capitalistas poderiam ser calibrados de dentro para fora, como se a condição periférica significasse apenas um retardo na forma de absorver as estruturas e dinamismos do capitalismo mas não comprometesse a capacidade das sociedade dependentes de controlar os fins e os meios do desenvolvimento. A evolução das economias dependentes passou a ser vista como uma espécie de eterno catching up, cuja eficácia revelaria a maior ou menor capacidade do Estado nacional de articular estratégias de acesso às tecnologias de vanguarda do processo de modernização das forças produtivas" (Sampaio Jr., 1997: 36).
\end{abstract}

Agreguemos que essa perda da especificidade brasileira não se restringe ao plano da economia, pois ela é vazada também para o nível da política (Oliveira, 1998). Um pouco como em Furtado (deve-se reconhecer), em Cardoso a qualidade de ser um capitalismo dependente não implica em qualquer configuração específica do regime político ou da forma do Estado - do que o texto de Serra e Cardoso (1978) é bem representativo, posto que para eles não há qualquer relação entre crise econômica e ditadura; pelo contrário, apesar de o Brasil ser um país de desenvolvimento dependente, a política aqui seguiria o mesmo figurino que nos centros capitalistas ${ }^{30}$. Abrir-se-iam brechas para avanços políticos e democráticos que mais não seriam que degraus galgados rumo a uma democracia nos tímidos moldes liberais ${ }^{31}$.

\footnotetext{
${ }^{30}$ Diz Oliveira: “Assim, o enorme esforço da teoria do subdesenvolvimento e de seu epígono corretivo, a teoria da dependência, terminam por deixar em aberto tais questões, com o que se regressa à indeterminação das relações entre economia, política, regimes políticos e formas do Estado. Vale sublinhar, destrói-se a própria inovação teórica do conceito de subdesenvolvimento, posto que se ele é singular, e não apenas um elo no continuum do desenvolvimento, as relações citadas não podem ser aleatórias; em outras palavras, buscando-se fugir do que parecia ser a camisa-de-ferro da tradição hegemônica no marxismo, de um determinismo à outrance, chega-se, metodologicamente, à possibilidade combinatória entre o subdesenvolvimento e qualquer forma de regime político e de Estado" (Oliveira, 1998: 09).

31 São particularmente exemplares a esse respeito alguns dos textos publicados em Modelo político brasileiro (1973) e Autoritarismo e democratização (1975a) — se bem que outros (1976, 1979 e 1980) também poderiam ser citados. Não é objetivo desta dissertação debruçar-se sobre tal aspecto de sua obra, mas de qualquer modo é interessante deixar registrado como o "autoritarismo" — este conceito problemático (Fernandes, 1978) - incrustado no Estado foi aos poucos ocupando nos trabalhos de Cardoso o posto de grande inimigo a ser combatido e como, dessa forma, uma democratização formal poderia dar cabo da tarefa
} 
Esses são, pois, os resultados dos estudos sobre a dependência levados adiante por Cardoso. Por tudo isso é que a temática do desenvolvimento capitalista brasileiro, que em Furtado converteu-se numa teoria da superação do subdesenvolvimento, em Cardoso tornou-se, no limite, uma teoria da acomodação subordinada da sociedade nacional ao sistema capitalista internacional. Novamente note-se que, se não produziu análises melhores, ao menos Marini percebeu desde o início esta faceta da obra de Cardoso.

\begin{abstract}
“(...) de maneira sub-reptícia, todo o esforço das Desventuras [Serra e Cardoso] se funda no sentido de borrar as diferenças entre o capitalismo nos países avançados e o capitalismo dependente, assimilando-os a um só processo: o desenvolvimento capitalista na periferia e no centro. O leitor poderá procurar com lupa no texto um indício, por pequeno que seja, de que a discussão que se está fazendo vai referida ao capitalismo dependente brasileiro: encontrará apenas a idéia de que há problemas e contradições no capitalismo brasileiro, que não tem outra particularidade que a de dar-se em um país da 'periferia', ou seja, em uma nação capitalista jovem, para usar uma expressão altamente ideológica. A utilização mesma do aparato conceitual 'centro-periferia', em deslocamento do que corresponde à dependência, indica um regresso ao redil da Cepal (a qual, por isso mesmo, é tão reivindicada ao longo do texto) e às ilusões desenvolvimentistas com que esta revestiu a primeira emergência da burguesia industrial, no pós-guerra, ilusões que, como assinalamos, a vida mesma destruiu. Mas, hoje, os novos ideólogos da burguesia brasileira estão obrigados a retomar esta tradição e a intentar dar credibilidade a um desenvolvimento capitalista brasileiro ao estilo norteamericano ou europeu. Em suma, nos encontramos ante um neodesenvolvimentismo, todavia envergonhado, mas que não tardará em ir perdendo suas inibições" (Marini, 1978: 102-103).
\end{abstract}

Tirante a evidente virulência que a citação de Marini porta, própria aliás de uma polêmica acirrada, o que há de interesse nesta passagem é que ela toca justamente no ponto exposto acima, qual seja, o de que Cardoso, ao tentar dar um passo adiante do pensamento cepalino-furtadiano, acabou por descaracterizar o desenvolvimento capitalista brasileiro, isto é, terminou por tisnar a especificidade capitalista brasileira tão frisada por Furtado. Isto é, não é claro o que nos diferencia dos países capitalistas centrais; talvez apenas a perspectiva de que uma inserção subordinada da sociedade nacional no sistema capitalista internacional seja algo de bom tamanho.

e, de roldão, resolver todos os impasses brasileiros. Vê-se por esse lado o que já havia apontado anteriormente, que as injunções externas impostas pelo capital internacional vão cedendo terreno e são encobertas por questões políticas tão-somente internas: esquecido (ou mais contundentemente, absolvido) o sistema capitalista internacional, o nó a ser desatado e que deixar-nos-ia a um passo do desenvolvimento estaria aqui dentro, apenas isso. Esse "movimento" na obra de Cardoso é detectado e esmiuçado por Sader (1997). 


\section{Capítulo 3 \\ SUBDESENVOLVIMENTO, DEPENDÊNCIA E DESENVOLVIMENTO NACIONAL}

\section{A Nação entre o subdesenvolvimento e a dependência}

Depois de havermos passado em revista, separadamente, ao pensamento de Celso Furtado (no primeiro capítulo) e aos estudos sobre a dependência de Fernando Henrique Cardoso (no segundo capítulo), ambos examinados a partir da mesma preocupação, qual seja, do lugar da Nação — da sociedade nacional - nessas interpretações do desenvolvimento capitalista brasileiro, o espaço deste terceiro capítulo é dedicado à retomada conjunta e integrada do que foi exposto anteriormente, de modo a podermos retirar daí considerações mais gerais sobre o tema desta dissertação.

Primeiramente, vimos como Celso Furtado, partindo de um amplo leque de influências, dentre as quais tem peso ímpar o pensamento econômico estruturado pela equipe da Cepal (donde a possibilidade de se falar em um pensamento cepalino-furtadiano), debruça-se sistematicamente sobre a problemática do desenvolvimento capitalista brasileiro, quer dizer, sobre o subdesenvolvimento brasileiro - e latino-americano fazendo com que o forte de sua produção radique justamente na elaboração de uma noção de subdesenvolvimento diversa daquelas inspiradas pela teoria econômica neoclássica, posto que sua noção entende o subdesenvolvimento como um desenvolvimento capitalista sui generis. De tudo isso, o que importa assinalar mais enfaticamente é o eixo das teorizações furtadianas, a Nação; através do itinerário do primeiro capítulo ficou patente 
como os diagnósticos e os prognósticos que Furtado formula para a sociedade e a economia brasileiras têm sempre o intuito precípuo de constituir a Nação, de consolidar a construção nacional. Nesse sentido, a consecução do desenvolvimento tem para Furtado, para além de qualquer outro fim, o objetivo da construção nacional, na medida em que construir a Nação implica, ao menos no caso brasileiro, submeter a toda a sociedade as escolhas e as opções de utilização do excedente econômico gerado internamente.

Depois, pudemos ver como a mesma ordem de preocupações apresenta-se, mutatis mutandis, nos estudos sobre a dependência levados a cabo por Fernando Henrique Cardoso. Neste caso, buscando captar melhor as vicissitudes do capitalismo internacional e a disposição do Brasil e da América Latina dentro dele, Cardoso formulou a noção de dependência e, dela derivada, a noção de desenvolvimento dependente; neste esquema interpretativo, a Nação - ou o Estado nacional - não deixa de estar presente e operar, posto que nem poderia ser diferente, haja vista que o próprio estatuto da dependência exige a presença do Estado nacional como mecanismo de intermediação entre os interesses capitalistas externos e os internos (sem o Estado nacional as relações entre o capitalismo internacional e o sistema político-econômico interno seria praticamente o mesmo de uma colônia). Entretanto, uma vez dado o Estado nacional, os estudos sobre a dependência de Cardoso não colocam em questão os vínculos entre o desenvolvimento dependente e a construção nacional: trata-se sim de verificar a inserção subordinada do Brasil no sistema capitalista internacional, isto é, sua posição dependente.

Posto isso, é de se notar que, observadas conjuntamente, tais análises ensejam considerações importantes quanto ao lugar da Nação no desenvolvimento capitalista brasileiro segundo cada uma delas; tais considerações já foram avançadas esparsamente nesta dissertação, cabe agora retomá-las de modo mais sistemático. Entendida a centralidade da "questão nacional" para Furtado, faz-se visível como sua interpretação do desenvolvimento capitalista brasileiro é perfeitamente convertida numa teoria da superação do subdesenvolvimento: segundo o economista brasileiro, o subdesenvolvimento é precisamente a precedência política e social de uma pequena parcela da população, as elites, sobre todo o resto da sociedade, precedência que resulta na forma pela qual o excedente econômico é utilizado para a satisfação de padrões de consumo e de absorção de progresso técnico que privilegiam tais elites; numa palavra, o que há é um desenvolvimento 
"mimético" cujo parâmetro é o centro capitalista (por conta dos laços de dependência externa), não a sociedade nacional. Sendo assim, a consolidação nacional passa necessariamente pela inversão dessas prioridades, fazendo com que as decisões de utilização do excedente econômico respeitem e repercutam os desígnios de uma sociedade efetivamente ampla, nacional - numa palavra, passa pela superação do subdesenvolvimento. Uma por outra, formar a Nação, concluir esse processo ainda em aberto, é para Furtado resolver a questão do subdesenvolvimento, posto que Nação e subdesenvolvimento, pelas razões aludidas acima e nos capítulos precedentes, são termos inconciliáveis e, no limite, antagônicos.

Noutro turno, o caso de Cardoso é diverso; como tentei mostrar no capítulo anterior, os estudos sobre a dependência de Cardoso vão no sentido de nuançar a oposição entre subdesenvolvimento, desenvolvimento e Nação, colocando-a em novo enquadramento. Aliás, é para tanto que vem à tona a noção de dependência, pois ela permitiria aquilatar melhor os liames entre a inserção subordinada de um país como o Brasil no sistema capitalista internacional - inserção dependente - e suas possibilidades de desenvolvimento nesse ambiente maior (abertas pela nova quadra do capitalismo, a da “internacionalização dos mercados"). As virtudes da análise dependentista na vertente de Cardoso já foram oportunamente louvadas, contudo o que aqui deve ser posto em evidência são suas conseqüências: operando dessa maneira, Cardoso chega ao desenvolvimento dependente, isto é, à percepção de que é possível algum desenvolvimento mesmo no interior dos laços da dependência, de maneira que, em contraste com Furtado, desenvolvimento e dependência deixam de ser termos teóricos ou condições históricas opostos. Nesse sentido, embora presente, a questão do Estado nacional é dada como estabelecida, quer dizer, resolvida sem maiores problemas. Não se trata mais de construir ou consolidar a Nação, como em Furtado, mas sim de inseri-la no sistema capitalista internacional, mesmo que em posição subordinada e dependente, e tentar aproveitar oportunidades de desenvolvimento ou crescimento econômico.

Sendo assim, a Nação, ou a sociedade nacional, passa do patamar de a questão em Furtado para a condição de mais um elemento, dentre outros, no esquema interpretativo de Cardoso. E aqui retornamos à matéria das continuidades e/ou rupturas entre o pensamento cepalino-furtadiano e o pensamento de Cardoso. Para além das continuidades, que há e são 
muitas, algumas das quais puderam ser mencionadas nesta dissertação, o que por ora interessa pôr em destaque são justamente as rupturas, mais especificamente uma ruptura, esta do lugar da Nação nas referidas interpretações do desenvolvimento capitalista brasileiro. Com efeito, cuida-se menos de tentar assinalar que esta percepção é "melhor" que aquela, que uma é mais "correta” que outra, que simplesmente identificar e investigar a distinção, retirando-lhe as conseqüências teóricas e os desdobramentos analíticos. De qualquer modo, tal deslocamento do lugar teórico da Nação é bem um índice dessas rupturas e serve para mostrar que, embora reconheça sua ascendência cepalina, Cardoso representa um ponto de inflexão nas teorias do desenvolvimento capitalista "periférico" ou "dependente".

Contudo, não haveria maior interesse nesse aspecto se fosse apenas para constatar o deslocamento do lugar da Nação entre Furtado e Cardoso. Dando um passo adiante, o que devemos apontar é que nesse passagem a radicalidade da proposta furtadiana é delida por Cardoso, quer dizer, a análise de Cardoso é bem menos incisiva que a de Furtado no que toca à natureza do sistema capitalista internacional. Evidentemente não estou dizendo que Furtado é $o$ radical, como se ele o fosse mais que autores de inspiração marxista e quejandos, o que não é o caso ${ }^{1}$; o que quero dizer é que, mesmo com seus limites bem claros, Furtado conseguiu ver o sistema capitalista internacional como um amplo campo de disputas e relações de força e poder, de oposições ferrenhas de interesses entre um centro e uma periferia capitalistas (perspectiva que, diga-se de passagem, estava originalmente em Prebisch e na Cepal, como vimos), o que não ocorre na mesma medida com Cardoso. Sem remontar às razões disso (já explanadas anteriormente), o fato é que o sistema capitalista na ótica de Cardoso é bem menos problemático e assimétrico (política e economicamente): nossa inserção nele não parece constituir empecilho, posto que dependemos apenas dos ajustes políticos internos. É nesse sentido estrito que a interpretação de Furtado carrega mais radicalidade que a de Cardoso: embora animado por uma louvável intenção de dar mais articulação à análise do desenvolvimento capitalista brasileiro, Cardoso acabou por desperdiçar uma faceta relevante do constructo furtadiano ${ }^{2}$.

\footnotetext{
${ }^{1}$ Convém lembrar mais uma vez que Furtado nunca pretendeu pôr abaixo o capitalismo, portando cobrar tal posição dele seria uma proposição descabida porque extrapola seu arcabouço teórico (que não contempla a idéia de uma revolução socialista ou comunista) ou suas pretensões práticas.

${ }^{2}$ Pode-se aduzir que, nesse aspecto particular, os estudos sobre a dependência feitos pela vertente marxista, isto é, Marini e Dos Santos, souberam dar mais atenção às injunções engendradas pelo capitalismo
} 
Uma outra expressão ou ressaibo dessa "diferença" de radicalidade, e que é também uma remissão daquela distinção do lugar da Nação que busco apontar nesta dissertação, pode ser vista na maneira como cada autor maneja e define sua noção de desenvolvimento. Lembrando o que já foi exposto, Furtado parte da crítica à teoria econômica neoclássica e a seu sucedâneo, as teorias da modernização, que fariam tábula rasa das condições históricas, sociais e políticas específicas a cada país e proporiam um caminho único para o desenvolvimento, sendo este entendido desde um ponto de vista meramente quantitativo, isto é, como simples aumento dos indicadores econômico (renda, PIB etc.). Para o economista brasileira esta é uma noção absolutamente insuficiente do que vem a ser desenvolvimento, posto que não contempla aspectos como os sociais e os políticos nem as especificidades históricas de cada lugar; assim, Furtado formula para si uma noção de desenvolvimento (digamos assim) "ampla", que comporta necessariamente tais aspectos sociais e políticos (o desenvolvimento econômico deveria ser também social e político, noutros termos) e que procura dar atenção à historicidade do desenvolvimento capitalista do país - é nesse sentido que, para Furtado, desenvolvimento é um processo substancialmente diverso daquele da "modernização", que nada mais é que crescimento econômico, como vimos. Assim é que tal concepção de um "desenvolvimento amplo" está presente em suas primeiras obras, porém será aprimorada nos escritos posteriores, quer dizer, em suma, ela é um dos pontos de convergência dos livros, artigos e escritos de Furtado.

Assim, se a noção de desenvolvimento de Furtado é "ampla", pois engloba política e sociedade à economia, a de Cardoso é, por assim dizer, mais restrita e, no limite, mais pobre. Mais pobre porque, ao fim e ao cabo, termina por entender desenvolvimento como espraiamento das relações capitalistas de produção, como industrialização; em poucas palavras, como crescimento econômico. É verdade que Cardoso esforçou-se por destacar os aspectos sociais do processo de desenvolvimento capitalista - daí o núcleo duro de seus escritos —, entretanto, ao sustentar que poderia ocorrer desenvolvimento mesmo que mantida a condição dependente do país, ele deixa entrever que as melhorias gerais da sociedade não seriam condição necessária para o desenvolvimento; ou seja, denota-se uma noção menos abrangente que a de Furtado. Não que esta seja uma noção mais incorreta que a outra, mas é que, comparadas, aquela de Furtado é mais ambiciosa —mais radical — que 
a de Cardoso; para esclarecer mais este ponto, pode-se dizer com a nomenclatura furtadiana que Cardoso chama de "desenvolvimento" o que na verdade não seria mais que "crescimento econômico" ou "modernização".

De novo, não seria possível dizer que existe uma noção correta e outra incorreta de desenvolvimento, mas sim que, comparativamente, a noção de Furtado acaba sendo mais sensível aos elementos políticos e sociais, portanto mais abrangente; ou, pelo outro lado, Cardoso satisfaz-se com uma noção mais limitada do que pode ser entendido como desenvolvimento. No caso de Furtado, essa noção deve ser mais ampla porque deve contemplar toda a Nação e dar conta da construção ou consolidação nacional como um de seus objetivos, questão que, como vimos, não se põe nos mesmos parâmetros para Cardoso; neste a consolidação nacional não é um problema, daí que sua noção possa ser mais circunscrita, ou, se se quiser, menos radical. Eis como a distinção da noção de desenvolvimento remete-se à distinção referente ao lugar da Nação em uma e outra interpretação. Ironicamente, a noção de desenvolvimento de Cardoso acaba sendo mais restrita que a de Furtado, apesar de o mote inicial dos trabalhos de Cardoso ter sido justamente uma interpretação mais abrangente do desenvolvimento capitalista brasileiro e latino-americano.

Desdobramento direto do que se disse até aqui é a chance de relativização das posições que Furtado e Cardoso têm ocupado na literatura acerca do desenvolvimento capitalista brasileiro e latino-americano. Embora semelhante matéria mereça mais espaço do que há disponível aqui, o que se pode dizer sucintamente é que em boa parte da literatura especializada, da qual Kay (1991), O’Brien (1975 e 1985), Palma (1987) e também Goldenstein (1994) são alguns exemplos, o trabalho da Cepal e, depois, o de Furtado é louvado como ponto inicial de um pensamento latino-americano bastante vigoroso mas que, malgrado suas conquistas, não conseguiu se livrar de algumas complicações de nascença (como o estruturalismo exacerbado e o economicismo), para o que os estudos sobre a dependência de Cardoso (a princípio com Faletto, mas depois sozinho) teriam significado a redenção: uma visão mais articulada do capitalismo, uma análise mais atenta às configurações dos jogos políticos internos e seu peso no determinação do desenvolvimento, a superação da divisão estanque entre interno e externo 
etc. Não que tais análises estejam de todo erradas, mas é que, pelo que vem sendo exposto desde o início desta dissertação, pode-se afiançar licitamente que nem o pensamento cepalino-furtadiano é tão simples nem a abordagem dependentista de Cardoso é tão virtuosa e imaculada quanto por vezes se quer fazer crer. Sobretudo, via de regra é elaborada uma contraposição entre o economicismo demasiado de Furtado e análise política e dialética de Cardoso, na qual os estudos dependentistas dissolvem os "erros" perpetrados pelo dualestruturalismo cepalino-furtadiano. Ora, tal entendimento somente pode ser mantido se fruto de um estudo feito a contrapelo do sentido geral das obras de Furtado, que englobam sim a política. Por certo que as limitações de Furtado devem ser reconhecidas e explicitadas (como busquei fazer aqui), porém é preciso igualmente reconhecer que, se sua análise utiliza lentes econômicas, o que quer dizer que a economia é a porta de entrada para os problemas do desenvolvimento capitalista brasileiro, isso de maneira alguma pode ser posto imediatamente na conta do economicismo, posto que sua perspectiva não prescinde, antes implica, a política. Além do mais, visto integralmente, o caminho de Furtado aponta na direção de um projeto de capitalismo democrático, não autocrático, tecnocrático nem, muito menos, autoritário (Cepêda, 1998: 222 e ss., especialmente 232). Naturalmente que isso não conflita necessariamente com o pensamento de Cardoso, mas justamente por isso permite-nos assinalar que a inovação deste deve ser nuançada: se realmente avançou nalguns pontos, noutros retrocedeu — como na compreensão da dinâmica do sistema capitalista internacional.

Seja como for, importa que todos os itens arrolados até aqui convergem para o mesmo ponto: enquanto a Nação encontra larga teorização em Furtado e constitui mesmo uma de suas preocupações mais graves, de modo que sua resolução seja passo necessário e fundamental da superação do subdesenvolvimento, em Cardoso ela está presente mas não forma um problema, antes a existência e o grau da dependência parecem derivar poucos efeitos negativos por sobre o Estado nacional. Ao passo que em Furtado o desenvolvimento, entendido como superação do subdesenvolvimento, exige a construção e a integração nacional e, no limite, o questionamento mesmo das relações entre centro e periferia capitalistas, em Cardoso desenvolvimento pode ser lido como o movimento de acomodação da Nação no sistema capitalista internacional - numa posição subordinada, bem entendido — sem que as relações de dependência sejam forçosamente postas em 
discussão. Para reafirmar o que já foi dito, a interpretação de Furtado converte-se numa teoria a um só tempo de consolidação nacional e de superação do subdesenvolvimento, em contraste com a de Cardoso, que se torna uma teoria da subordinação da Nação ao sistema capitalista internacional.

Mas isso não é tudo. A percepção que cada um dos autores aqui em mira tem das possibilidades e dos limites do desenvolvimento capitalista brasileiro representa bem outra entrada para a distinção entre um e outro quanto ao lugar e ao papel da Nação, para o que, ademais, devemos envolver também a maneira pela qual um e outro entende a dinâmica capitalista internacional e os condicionantes dela emanados.

Lembremo-nos de que a extinção de nosso "desenvolvimento mimético", vale dizer, de nosso subdesenvolvimento, é para Furtado função do reordenamento interno do modo como o excedente econômico é utilizado, mas também e em grande medida da dinâmica capitalista internacional; quer dizer, para Furtado as possibilidades de desenvolvimento efetivamente existem mas apenas na exata proporção em que as condições internacionais (o velho sistema centro-periferia) permitem - o que deixa ainda mais patente sua perspectiva, segundo a qual “(...) para compreender as causas da persistência histórica do subdesenvolvimento, faz-se necessário observá-lo como parte que é de um todo em movimento, como expressão da dinâmica do sistema econômico mundial engendrado pelo capitalismo industrial" (Furtado, 1980: 23). Ou seja, justamente por ser parte de um "todo" é que a superação do subdesenvolvimento, ainda que tenha as condições internas favoráveis, não pode prescindir ou ignorar a "dinâmica do sistema econômico mundial". Nesse sentido, Furtado não deixa de acreditar na possibilidade de mudança — não fosse assim ele não teria produzido o que produziu —, porém não é ingênuo a ponto de crer que a conjuntura internacional pouco importa ou permanece imutavelmente propícia. Daí que, sendo o desenvolvimento, como temos visto, a consolidação da sociedade nacional, as possibilidades da Nação estão igualmente a depender do movimento capitalista internacional. Assim é em Furtado.

Em Cardoso a questão apresenta-se com algumas, porém fundamentais, diferenças. Quanto ao peso das condições internas, sobretudo políticas e sociais, na determinação das possibilidades de desenvolvimento, não é preciso dizer mais do que já foi dito até aqui: ele (o peso) é grande e determinante. O que deve ser assinalado é que, embora reconheça que 
tais possibilidades sejam determinadas "em última instância" pelo sistema capitalista internacional, essa determinação é vista sem ser problematizada. Conforme referido no capítulo anterior, a interpretação de Cardoso entende que há tal determinação, mas a vê sem a radicalidade da visão furtadiana; noutros termos, parece vê-la de modo bastante amistoso, sem dar a necessária consideração ao antagonismo presente no sistema capitalista internacional - não obstante o fato de, como quer Cardoso, as relações entre Centro e Periferia terem adquirido contornos mais articulados. Sendo assim, e na medida em que a dependência não é um fator impeditivo, as possibilidades do desenvolvimento capitalista brasileiro surgem como franqueadas e a depender apenas dos arranjos políticos e sociais internos. Assim é que, uma vez que a "questão nacional” já está dada no esquema interpretativo de Cardoso, a dinâmica do sistema capitalista internacional tem pouca ou nenhuma relação com a consolidação da Nação. São instâncias completamente diversas e separadas.

Interessante notar no que acabei de expor é como as condições internacionais - o sistema capitalista internacional - informam cada uma das interpretações aqui em mira e como aquelas têm importância variável nestas. Neste caso, iluminando a questão das possibilidades de desenvolvimento brasileiro em Furtado e em Cardoso e sua repercussão sobre a "questão nacional”, também em cada um dos autores. Parece não serem necessários maiores esclarecimentos a respeito de quão interligadas são uma e outra questão; de qualquer forma, o que foi exposto tem valia pelo que reflete da distinção que há entre os autores quanto à posição da Nação e da sociedade nacional em seus pensamentos. Em Cardoso a questão das possibilidades de desenvolvimento prescinde da questão da Nação e a deixa na dependência apenas dos arranjos políticos internos corretos; quanto às condições internacionais, as do sistema capitalistas, estas parecem não constituir problema pois estão sempre lá, imutáveis. Já em Furtado ocorre algo diverso, pois o desenvolvimento somente pode ser entendido se trazer consigo a consolidação da sociedade nacional; tudo isso, porém, está inserido num todo maior, o sistema capitalista, e as injunções e determinações impostas por ele não podem ser eludidas. O resultado desse panorama é que o desenvolvimento é, na chave furtadiana, um processo dinâmico e repleto de tensões, constantemente repostas, e por isso mais complexo do que julga Cardoso. 
Mais uma vez retornamos ao ponto que é o objetivo precípuo desta dissertação. Como vimos, a partir da perspectiva aqui escolhida é possível traçar em cada pensamento uma linha por onde trafega a questão da Nação, linha essa que tem diferença considerável de Furtado a Cardoso e que tanto os capítulos precedentes quanto o que foi exposto até aqui tiveram o fito de explicitar. Fosse apenas por isso, o que desejo traçar já estaria suficientemente estabelecido e patente. Ocorre que tal linha não se detém aqui, antes segue adiante: isso quer dizer que a distinção acima referida persiste para além dos escritos analisados aqui e se repõe, na mesma proporção, nas formulações mais recentes dos referidos autores, sobretudo quando versam sobre as mudanças pelas quais passa o sistema capitalista internacional e, especialmente, sobre os efeitos dessas mudanças num país de desenvolvimento capitalista periférico ou dependente.

Desta feita, retomam-se os termos da discussão sobre as possibilidades do desenvolvimento brasileiro, apenas que agora diante da chamada "transnacionalização" ou, mais comumente, "globalização", o que arroja luz nova sobre a mesma matéria, o lugar da sociedade nacional. Nesse sentido, um estudo - ainda que muito rápido e bem menos acurado do que a relevância do assunto exige - desse novo momento das interpretações sobre o subdesenvolvimento e a dependência brasileira nessa nova quadra do capitalismo traz-nos mais subsídios para indicar que aquela perspectiva acerca da Nação, que esta dissertação vem perseguindo, mantém-se basicamente a mesma, seja para Furtado, seja para Cardoso, ainda hoje.

\section{A distinção reeditada: Nação, subdesenvolvimento, dependência e globalização}

O ensejo deste item é indicar que a distinção entre Furtado e Cardoso a respeito do lugar da Nação em suas respectivas interpretações do desenvolvimento capitalista brasileiro 
mantém-se ao longo de suas trajetórias teóricas e práticas e vem rebater na maneira como cada um deles equaciona a questão nacional diante da globalização. De partida, é forçoso esclarecer que com esse expediente não quero compreender como nossos autores lidam com as hodiernas mudanças estruturais pelas quais passa o sistema capitalista internacional — a "globalização", pela vulgata midiática —, isto é, como eles as explicam e como integram-nas em seus arcabouços teóricos; embora tal tarefa tenha sua relevância e constitua legítimo objeto de estudo, a questão aqui é um pouco outra, conforme exposto linhas acima. Nesse sentido, o que vem a ser tais mudanças econômicas estruturais e a explicação que lhes dão os referidos teóricos do desenvolvimento capitalista brasileiro tem pouco interesse, pois o que interessa é acompanhar como eles vislumbram os rebatimentos da "nova ordem internacional" sobre um país periférico e dependente como o Brasil. O que faz com que este trecho não esteja descolado do restante da dissertaçãoé a idéia de que, sob o aspecto que desejo evidenciar neste item, as perspectivas de Furtado e de Cardoso estão informadas pelos modos respectivos de interpretar o lugar da Nação e da sociedade nacional no desenvolvimento capitalista brasileiro tal qual visto até aqui; ou seja, a perspectiva de hoje é um reflexo daquela perspectiva básica de cada um dos autores, de modo que a primeira é mais um elemento que evidencia a segunda.

A natureza das mudanças estruturais pelas quais passa atualmente o sistema capitalista internacional é objeto de largas e longas discussões - quiçá devida à novidade do tema -, o que faz com que sua compreensão e sua explicação varie de estudioso a estudioso ${ }^{3}$. De qualquer modo, é possível esboçar um quadro básico, que aliás é aquele que está de certa maneira em Furtado e em Cardoso, cujo ponto nodal está na "transnacionalização" das atividades econômicas e na formação de grandes conglomerados empresariais, do que é resultado a transnacionalização da atuação dessas empresas, isto é, para além das fronteiras de seus países de origens; some-se a isso o aumento dos fluxos de investimentos internacionais e a transformação de parte da periferia capitalista em território de valorização de capitais (Hirst \& Thompson, 1998) ${ }^{4}$. Todavia, um outro aspecto desse

\footnotetext{
${ }^{3}$ Sobre a "globalização", em vários enfoques possíveis, veja Batista Jr. (1997a, 1997b), Beck (1998), Chesnais (1995), Fiori (1997), Harvey (1993) e Magalhães Fº (1998). Já sobre o Brasil no interior desse torvelinho, ver Gonçalves (1994), Singer (1996) e Teixeira (1994).

${ }^{4} \mathrm{O}$ trabalho de Hirst e Thompson é interessante pois procura pôr em termos claros o que há de efetivo na "globalização", sem cair na apologia de um "admirável mundo novo" nem dizer que ela não passa de uma falácia ideologizada dos capitalistas.
} 
processo que se assoma mais e mais é o do peso da finanças no sistema capitalista internacional: assim, o capital financeiro assume crescente importância (Belluzzo, 1997), ditando mesmo em grande medida os rumos do processo capitalista e de tal maneira que alguns estudiosos julgam lícito fazer referência a um "regime de acumulação predominantemente financeiro" (Chesnais, 1997) ou à "financeirização" como um novel "padrão sistêmico" do capitalismo contemporâneo (Braga, 1997) 5 .

Naturalmente que o processo de internacionalização do capitalismo é por demais amplo para ser caracterizado aqui; nesse sentido e como nosso foco não repousa sobre tal processo em si, podemos lançar mão genericamente da palavra "globalização" para referilo, com o que fica alertado que, apesar de sua falta de rigor, o vocábulo serve bem ao propósito de indicar as transformações capitalistas contemporâneas. Seja como for, conforme assinalei, não são as transformações capitalistas contemporâneas que nos interessam em si, mas sim suas conseqüências sobre o desenvolvimento capitalista brasileiro, particularmente tal qual visto por Furtado e Cardoso. Desta feita, o exposto acima permite vislumbrar os desafios impostos ao Brasil e aos demais país periféricos pelo processo capitalista contemporâneo, uma vez que as tendências deste parecem ir no sentido de borrar as fronteiras do espaço nacional e de solapar — ou ao menos dificultar bastante — as estratégias de desenvolvimento baseadas na integração nacional, que são substituídas no caso dos países capitalistas periféricos pela integração subordinada ao circuito econômico e financeiro internacional. Em poucas palavras, o risco que as mudanças do sistema capitalista internacional embute nesse processo é o de que a integração internacional torne-se mais atraente que a nacional justamente porque a acumulação capitalista desenrola-se mais e mais em patamar internacional.

É precisamente esse panorama que convém destacar aqui, por tudo que ele representa aos países periféricos (sobretudo Brasil). Esse rebatimento da globalização nos países periféricos e dependentes é bem retratado por Sampaio Jr.:

\footnotetext{
“Ao intensificar a concentração e a centralização de capitais, o desenvolvimento desigual do sistema capitalista mundial provocou deslocamentos no poder econômico e político que tenderam a minar as bases do Estado nacional burguês. No plano econômico, o cerne do problema está na dificuldade de harmonizar o caráter predatório da concorrência com a capacidade da sociedade nacional de preservar a coerência de seus sistemas produtivos e a reprodução de mecanismos de solidariedade
}

\footnotetext{
${ }^{5}$ Dos mesmos autores podem ser consultados Chesnais (1996) e Braga (1993).
} 
orgânica entre as classes sociais. No plano político, a questão central é que a disputa pelo monopólio das novas tecnologias e pelo controle dos mercados mundiais acirrou as rivalidades entre Estados nacionais. Tudo isto é agravado pelo fato de que a ausência de mecanismos supranacionais de coordenação das políticas econômicas dos países centrais reduziu o ritmo do processo de acumulação em escala mundial, exacerbando as pressões para a defesa da estabilidade das moedas nacionais" (Sampaio Jr., 1997: 13).

O problema que se coloca então é o da permanência do espaço nacional como locus da consolidação social, política, econômica e cultural da Nação e como ambiente de internalização autônoma da dinâmica capitalista internacional; num palavra, a manutenção ou não do poder do Estado nacional de exercer suas atividades normais, administrativas, de regulação da economia, da política, da vida em sociedade etc. Sendo assim, para um país cuja pretensão de desenvolvimento nacional sempre foi muito forte - inspirada em larguíssima medida pelo desenvolvimentismo que nasceu do dual-estruturalismo cepalinofurtadiano - as mudanças capitalistas contemporâneas surgem como momento crítico e gravoso, no qual as noções de subdesenvolvimento e de dependência têm sua atualidade demonstrada e, pode-se dizer, revivificada. Resta saber as consequiências, positivas e/ou negativas, que daí virão e, mais ainda, como elas são imaginadas e compreendidas por cada uma das perspectivas analíticas em escrutínio nesta dissertação. As diferenças entre a visão de Furtado e a de Cardoso estão na exata medida da diferença entre suas concepções sobre sociedade nacional no desenvolvimento capitalista brasileiro; na verdade, como já foi dito, as visões de um e outro hoje estão informadas e recebem a forma daquelas de ontem.

Analista atento e atualizado do capitalismo internacional - haja vista que ele sempre assinalou a importância dos condicionamentos externos ao subdesenvolvimento, sendo que este sempre foi estudado como um parte do sistema econômico mundial —, Furtado sabe os contornos que o capitalismo vai assumindo e os desafios daí derivados postos hoje ao desenvolvimento nacional de países periféricos como o Brasil, do que dão mostras seus textos mais recentes, que aliam análises internacionais e considerações sobre a situação brasileira. No início dos anos 1990 dizia ele que, com "o avanço da internacionalização dos circuitos econômicos, financeiros e tecnológicos, debilitam-se os sistemas econômicos nacionais" e que países de marcada heterogeneidade cultural e/ou econômica terão de enfrentar pesadas forças desarticuladoras (Furtado, 1992b: 57). Nesse mesmo texto Furtado aponta precisamente a configuração do quadro internacional atual e as conseqüências daí decorrentes, valendo a reprodução deste trecho: 


\begin{abstract}
"A estrutura internacional de poder evoluiu para assumir a forma de grandes blocos de nações-sede de empresas transnacionais que dispõem de rico acervo de conhecimentos além de pessoal capacitado. O intercâmbio internacional de serviços, particularmente os financeiros e tecnológicos, cresce em detrimento dos de bens tradicionais. Na dinâmica desse sistema, prevalecem as forças tendentes a reproduzir a atual clivagem desenvolvimento/subdesenvolvimento. Para escapar a esse sistema de forças articuladas planetariamente, é necessário que se conjugue vontade política fundada em amplo consenso social com condições objetivas que poucos países do Terceiro Mundo reúnem atualmente" (Furtado, 1992b: 58).
\end{abstract}

Ou seja, na opinião de Furtado a dinâmica capitalista atual vai no sentido de realimentar a "clivagem desenvolvimento/subdesenvolvimento"; quer dizer, dispensadas as apologias do mercado mundial livre, pleno de possibilidades para todos os países, o que há de fato é a tendência de que a configuração mundial de um centro e uma periferia seja reposta, apenas que agora insuflada pelas finanças internacionalizadas. Ademais, a globalização, ao menos do ponto de vista dos países periféricos e tal qual a percebe Furtado, significa menos uma "integração internacional" que probabilidade de estancamento do processo de integração nacional em suas dimensões política, social, cultural e, sobretudo, econômica. Para dizê-lo convenientemente, no entender do economista brasileiro pior será se os países periféricos simplesmente lançarem por terra, supostamente em favor do mercado externo, os efeitos positivos advindos do fomento do mercado interno.

\footnotetext{
"Os sistemas econômicos de grandes dimensões territoriais e acentuadas disparidades regionais e estruturais - Brasil, Índia e China aparecem em primeiro plano — dificilmente sobreviverão se perderem a força coesiva gerada pela expansão do mercado interno. Nesses casos, por mais importante que seja a inserção internacional, esta não é suficiente para dinamizar o sistema econômico. Num mundo dominado por empresas transnacionais, esses sistemas heterogêneos somente sobrevivem e crescem por vontade política apoiada em um projeto com raízes históricas" (Furtado, 1992b: 63).
}

Vê-se pois como no pensamento recente de Furtado permanece e mesmo fortalecese a idéia do Brasil como país ainda em formação, como conjunto tenso de possibilidades que, se bem aproveitado e respeitadas as peculiaridades nacionais, pode vir a se concretizar; porém, como tal conjunto não permanece estático no tempo, antes sofre os fluxos e refluxos da dinâmica histórica, a dificuldade está em que ele está cada vez mais estreito, na mesma medida em que as mudanças capitalistas avançam e o Estado nacional sofre modificações que põem em xeque noções extremamente valiosas para o dual-estruturalismo furtadiano, 
como as de políticas econômicas nacionais e de integração nacional. "Se deixarmos de lado toda referência a sistema econômico nacional e a produtividade social, a idéia mesma de política econômica perde seu significado corrente (...)" (Furtado, 1992a: 30). É evidente que para Furtado não se trata simplesmente de negar a integração econômica brasileira ao sistema capitalista internacional e querer a via de um desenvolvimento autárquico, mas sim de pretender indagar qual a posição do Brasil hoje nesta integração; noutros termos, o economista brasileiro entende que o novo quadro econômico internacional surgido com a globalização pode até possuir efeitos benéficos, mas é especialmente maléfico para países que não conseguiram sequer estruturar e sedimentar uma sociedade e uma economia minimamente integradas, quer dizer, com reduzida concentração de renda, diminuta heterogeneidade estrutural, políticas sociais em funcionamento adequado etc. - enfim, aquilo que o dual-estruturalismo preconizara em seus tempos áureos. Este ponto é importante, como o próprio Furtado o indica:

\footnotetext{
"Seria ingênuo ignorar que a evolução das técnicas conduz à planetarização dos circuitos econômicos sob o controle de empresas transnacionais. Mas como desconhecer que o esvaziamento dos sistemas decisórios nacionais será de conseqüências imprevisíveis para a ordenação política de vastas áreas do mundo, em particular para os países subdesenvolvidos de grande área territorial e profundas disparidades regionais de renda, como é o Brasil?" (Furtado, 1992a: 30).
}

Em suma, em sendo um país ainda por ser concluído (econômica, política e socialmente), Furtado entende que o panorama que espera o Brasil, a julgar pelo que se tem visto até então, é notadamente grave. E mais ainda, as tendências atuais do sistema capitalista internacional apontam no sentido da inconclusão ou mesmo da interrupção desse processo formativo nacional, fazendo do Brasil uma "construção interrompida".

\footnotetext{
"Na lógica da ordem econômica internacional emergente parece ser relativamente modesta a taxa de crescimento que corresponde ao Brasil. Sendo assim, o processo de formação de um sistema econômico já não se inscreve naturalmente em nosso destino nacional."; "Em um país ainda em formação, como é o Brasil, a predominância da lógica das empresas transnacionais na ordenação das atividades econômicas conduzirá necessariamente a tensões inter-regionais, à exacerbação de rivalidades corporativas e à formação de bolsões de miséria, tudo apontando para a inviabilização do país como projeto nacional" (Furtado, 1992a: 13 e 35, respectivamente).
}

A visão de Furtado a respeito dos efeitos da globalização sobre o desenvolvimento capitalista brasileiro é patente: muito mais deletéria que positiva, a globalização põe em xeque a formação do Brasil como uma integral sociedade nacional — atente-se para o fato 
de que Furtado não desiste de seu "projeto" nacional, porém sabe que ele torna-se dia a dia mais difícil. Seguramente o Estado nacional não deixará de existir nem sua importância para o processo de desenvolvimento ${ }^{6}$, contudo é igualmente certo - ao menos é assim que Furtado entende o processo — que hoje ele não é mais o ente plenipotenciário de outrora, de modo que idéias como "desenvolvimento nacional" ou "integração nacional", pelo que dependem do Estado nacional no esquema furtadiano, tornam-se francamente problemáticas. Problemáticas não no sentido de "incorretas" ou no de terem sido desmanchadas pela inexorabilidade do tempo, tornadas pois "obsoletas", mas no de que suas bases são fortemente abaladas pelos novos rumos do capitalismo internacional; e no caso de "bases", leia-se o Estado nacional. Portanto, tomando-se o tema a partir da perspectiva furtadiana, mais que um complicação teórica (na medida em que um dos esteios deste arcabouço interpretativo é modificado), a questão deste "novo" Estado é importante porque deixa expostas as dificuldades atuais com que o desenvolvimento capitalista brasileiro - que no caso de Furtado é antes de tudo nacional - se debate e que procura transpor para viabilizar este país como Nação.

Nesse sentido, a tendência do sistema capitalista internacional parece apontar numa direção que, para Furtado, é a oposta daquela da formação da sociedade nacional. De um lado, o canto de sereia da "integração internacional", de outro, a tentativa de integração nacional, ainda inconclusa; e o problema é bem esse: buscar a integração no "mercado globalizado", que é muito mais competitivo e hierarquizado, quando se tem a formação nacional ainda por terminar. $\mathrm{O}$ risco é terminarmos sem uma coisa ou outra.

\begin{abstract}
"A atrofia dos mecanismos de comando dos sistemas econômicos nacionais não é outra coisa senão a prevalência der estruturas de decisões transnacionais, voltadas para a planetarização dos circuitos de decisões. A questão maior que se coloca diz respeito ao futuro das áreas em que o processo de formação do Estado nacional se interrompe precocemente, isto é, quando ainda não se há realizado a homogeneização nos níveis de produtividade e nas técnicas produtivas que caracterizam as regiões desenvolvidas. As disparidades geográficas de um mesmo sistema econômico são uma característica do subdesenvolvimento, a qual surge nítida nos países de grande extensão territorial" (Furtado, 1992a: 24-25).
\end{abstract}

O que temos então é que, na visão de Furtado, aquela oposição entre subdesenvolvimento (alimentado pela dependência) e consolidação nacional tantas vezes assinalada é acirrada pela globalização, que a potencializa e a eleva a níveis extremamente

\footnotetext{
${ }^{6}$ Veja Singer (1997).
} 
danosos. Num passagem que capta bem a gravidade do momento que desejo destacar, Sampaio Jr. (1997: 21) aponta que,

\begin{abstract}
"Portanto, na fase atual do processo de desenvolvimento capitalista, as economias periféricas já não contam com a possibilidade de fuga para frente pela aceleração do crescimento econômico estratégia que abria espaço para que se avançasse no progresso de construção das bases materiais, sociais, políticas e culturais de um Estado nacional burguês. Sem possibilidade de controlar nem os fins nem os meios do processo de acumulação, a contradição entre dependência e desenvolvimento nacional torna-se aguda e ameaça transformar-se em antagonismo aberto" (Sampaio Jr., 1997: 21).
\end{abstract}

O que resultará dessa disjuntiva "Nação versus globalização" é algo que ainda se verá nos anos vindouros, porém Furtado adianta que, pelo panorama geral, o horizonte brasileiro não é nada tranqüilo. O resultado efetivo, porém, é uma grande interrogação. Como Furtado mesmo diz, "não ignoramos que o tempo histórico se acelera, e que a contagem desse tempo se faz contra nós. Trata-se de saber se temos um futuro como nação que conta na construção do devenir humano. Ou se prevalecerão as forças que se empenham em interromper o nosso processo histórico de formação de um Estado-Nação" (Furtado, 1992a: 35) ${ }^{7}$.

Vê-se pois como a Nação permanece como um dos eixos (se não o principal) do pensamento de Furtado. Resta patente também como a compreensão que o economista brasileiro tem (e sempre teve) dos condicionamentos postos pelo sistema capitalista internacional ao desenvolvimento capitalista brasileiro é atualizada aqui. Quer dizer, Furtado não elide o peso determinante que a dinâmica internacional tem para os rumos brasileiros, e é por isso que ele atenta sobremaneira para como a globalização vai solapando as possibilidades da sociedade nacional. Igualmente, é pleno de significado o fato de Furtado acreditar que, apesar das agruras diversas que lhe são impostas, é justamente pela via da idéia de Nação que se pode minorar as consequiências deletérias do capitalismo internacional. Não se trata, é preciso esclarecer, de investir em algo ferido de morte mas sim de evidenciar que apostar numa imaginada "integração internacional" a desmedro da integração nacional somente irá multiplicar os danos sociais, políticos, econômicos e culturais de um país ainda em formação, levando-o, no limite, à barbárie.

\footnotetext{
${ }^{7}$ Veja também Sampaio Jr. (1999: 437-446).
} 
"Na lógica da ordem econômica internacional emergente parece ser relativamente modesta a taxa de crescimento que corresponde ao Brasil. Sendo assim, o processo de formação de um sistema econômico já não se inscreve naturalmente em nosso destino nacional. O desafio que se coloca à presente geração é, portanto, duplo: o de reformar as estruturas anacrônicas que pesam sobre a sociedade e comprometem sua estabilidade, e o de resistir às forças que operam no sentido de desarticulação do nosso sistema econômico, ameaçando a unidade nacional" (Furtado, 1992a: 13). ${ }^{8}$

Essa mesma ordem de idéia está exposta no mais recente ${ }^{9}$ texto de Furtado (2000). Ali, embasando "reflexões sobre a crise brasileira", estão as mesmas idéias, noções e categorias furtadianas: "subdesenvolvimento", "desenvolvimento mimético", "Nação", o papel preponderante dos intelectuais etc.; todas servindo para a explicitação de que os problemas brasileiros atuais - a crise brasileira — têm origem naquele mesmo processo de subdesenvolvimento identificado por Furtado há décadas: a mesma reprodução de padrões de consumo de sociedades capitalistas centrais e a mesma modalidade de utilização do excedente econômico ${ }^{10}$. Como conseqüência, a exacerbação dos efeitos nocivos do subdesenvolvimento, ainda hoje.

\begin{abstract}
"Portanto, a crise que agora aflige nosso povo não decorre apenas do amplo processo de reajustamento que se opera na economia mundial. Em grande medida ela é o resultado de um impasse que se manifestaria necessariamente em nossa sociedade, a qual pretende reproduzir a cultura material do capitalismo mais avançado privando a grande maioria da população dos meios de vida essenciais. Não sendo possível evitar que se difundam, de uma ou outra forma, certos padrões de comportamento das minorias de altas rendas, surgiu no País a contrafação de uma sociedade de massas em que coexistem formas sofisticadas de consumo supérfluo e carências essenciais no mesmo estrato social, e até na mesma família (Furtado, 2000: 03).
\end{abstract}

Posto isso, o mais relevante a destacar é que, de modo ainda mais patente, é a Nação que Furtado busca manter como o ponto nodal das possibilidades do desenvolvimento capitalista brasileiro no bojo de uma globalização vista sem peias, subterfúgios,

\footnotetext{
${ }^{8}$ Interessante acrescentar que a resistência aos efeitos negativos da globalização virão também, segundo Furtado, da esfera cultural: "O freio a esse processo de integração [internacional] virá de fatores culturais, pois não será surpresa se grupos de população lutarem para preservar suas raízes culturais e valores específicos ameaçados de desaparecer pela homogeneização dos padrões de comportamento que a racionalidade econômica impõe". (Furtado, 1992a: 31)

${ }^{9}$ Ao menos para o momento de redação desta dissertação. Veja também Furtado (1994), no qual as mesmas idéias se reproduzem.

10 "É certo que a causa imediata da crise que acabrunha o país foi o forte desequilíbrio da balança de pagamentos para o qual concorreram fatores de origem interna e externa. Mas, que esperar de um processo de crescimento que derivava seu dinamismo da reprodução indiscriminada de padrões de consumo de sociedades que já alcançaram níveis de produtividade e bem-estar muitas vezes superiores aos nossos? Como não perceber que os elevados padrões de consumo de nossa chamada alta classe média tem como contrapartida a esterilização de parte substancial da poupança e aumenta a dependência externa do esforço de investimento?
} 
eufemismos ou superficialidade. Também neste texto, a exemplo dos anteriores, é a idéia de Nação ou sociedade nacional que pode contra-arrestar a tendência de acentuação das disparidades regionais, econômicas e sociais, os impasses culturais e as tensões políticas. A passagem seguinte mostra isso nitidamente, quer dizer, mostra a Nação ocupando o centro do pensamento de Furtado, de modo que sua interpretação mantém-se na qualidade de teoria da superação do subdesenvolvimento e de consolidação nacional, a um só tempo, conforme já apontado.

\begin{abstract}
"A globalização opera em benefício dos que comandam a vanguarda tecnológica e exploram os desníveis de desenvolvimento entre países. Isso nos leva a concluir que países com grande potencial de recursos naturais e acentuadas disparidades sociais — caso do Brasil — são os que mais sofrerão com a globalização. Isso porque poderão desagregar-se ou deslizar para regimes autoritários de tipo fascista como resposta às tensões sociais crescentes. Para escapar a essa disjuntiva temos que voltar à idéia de projeto nacional, recuperando para o mercado interno o centro dinâmico da economia. A maior dificuldade está em reverter o processo de concentração de renda, o que somente será feito mediante uma grande mobilização social. (...) Numa palavra, podemos afirmar que o Brasil só sobreviverá como nação se transformar numa sociedade mais justa e preservar sua independência política." (Furtado, 2000: 07, itálicos meus).
\end{abstract}

Para além do interesse mais geral que há na discussão que Furtado faz dos problemas brasileiros atuais, há aquele que diz respeito a esta dissertação. Ou seja, os escritos furtadianos mais recentes deixam claro que a Nação ainda é operante, muito operante, em seu pensamento e ocupa o mesmo lugar de relevância que outrora, a despeito dos avatares do sistema capitalista. Nesse sentido, não há como concordar com o argumento geral de M. O. Santos, que pretende ter demonstrado a falência do projeto furtadiano de integração nacional pela via do mercado interno (Santos*, 1998: 240), falência que teria sido reconhecida por Furtado mesmo ${ }^{11}$. Ora, o que vimos até aqui, conforme pretendi indicar, é a permanência da Nação como um dos eixos centrais do pensamento furtadiano, o que o texto de 2000 atesta cabalmente; é fato que o economista brasileiro reconhece as imensas dificuldades e tensões que a idéia de projeto nacional enfrenta hoje, porém tal reconhecimento não pode — nem tem como — ser tomado como

As tensões estruturais que daí resultam estão na origem das pressões inflacionárias incontroláveis. Nessas circunstâncias, o custo da estabilidade de preços tende a ser a recessão" (Furtado, 2000: 02).

${ }^{11}$ Diz Santos que "Não tardou para que Furtado esbarrasse na inviabilidade de seu projeto, derrota atestada pelo próprio autor, que percebia que o movimento de acumulação e reprodução do capital regido por uma lógica em absoluta contradição com a constituição da nação 'autônoma'. (...) Para a periferia capitalista, então, a consolidação da nação 'auto-sustentada' passa a ser, no mínimo, uma 'oportunidade' perdida" 
uma "derrota"; ao que parece, é justamente diante da gravidade que a "globalização" pode significar que a idéia de Nação ganha nova relevância na visão de Furtado.

Seja como for, a pretensão de indicar como a perspectiva furtadiana acerca dos efeitos das mudanças capitalistas sobre o Brasil ilumina sua concepção das relações entre centro e periferia e, sobretudo, seu entendimento do lugar da Nação (denotando uma continuidade) foi razoavelmente cumprida. Resta dizer que o mesmo expediente pode ser aplicado agora a Cardoso, com resultado similar — entenda-se, explicitando uma perspectiva a respeito da globalização que mostra que seu entendimento do sistema capitalista internacional e do lugar da Nação no desenvolvimento capitalista brasileiro é em essência o mesmo que o dos anos 1960 e 1970. Vale a pena examinar isso mais de perto.

Antes de tudo, cumpre dizer que a produção recente de Cardoso não tem o mesmo tamanho da de Furtado nem o mesmo estatuto: Furtado ainda reina na esfera dos trabalhos acadêmicos e estudos teóricos, embora saiba da tênue fronteira entre teoria e prática, enquanto Cardoso, como se sabe, há muito enveredou pelo caminho político-partidário, ou seja, obedece a critérios outros. Se bem esse aspecto deva ser lembrado, ele não invalida o teor do pensamento do Cardoso "político", posto que este não deixa de estar informado e baseado, nalguma medida, por seu conhecimento adquirido anos antes. Posto isso, o material dessa fase de Cardoso é constituído maioritariamente, pelo menos para o tema aqui em mira, por discursos e conferência e algumas entrevistas, cujo objeto central é a globalização e seus efeitos. Nesses, vistos em conjunto, o que ressalta é aquela mesma perspectiva que Cardoso sustentava em seus estudos sobre a dependência: uma visão "estática" (por assim dizer) do capitalismo internacional, no qual os antagonismos e as relações de poder e de hierarquia entre países são escamoteados; não se trata de fazer aqui considerações valorativas a respeito dessa visão hoje, mas apenas relacioná-la com o pensamento "acadêmico" de Cardoso e indicar como a Nação se encaixa aí da mesma maneira que se encaixava lá, nos anos de 1960 e 1970, conforme vimos. No geral, a idéia de Nação, de um Estado nacional, está presente, porém ela não é problematizada diante das tendências das mudanças contemporâneas do sistema capitalista internacional; mais uma vez, é como se nossa integração ao sistema capitalista fosse possível de ser realizada sem

(Santos*, 1998: 240-241). Note-se que a tese de Santos é anterior ao último texto de Furtado citado mais acima. 
impasses nem tensões, nem se cogita sobre o significado de uma inserção em posição subordinada. Como se vê, a mesma perspectiva de outrora.

S. Velasco e Cruz debruçou-se sobre esse material e é pertinente ver o que ele encontrou sobre a globalização no pensamento do Cardoso "político". Segundo Velasco e Cruz, a globalização aparece no discurso recente de Cardoso de modo bastante nebuloso e impreciso, comportando vários significados e características (Velasco e Cruz, 1998: 59-60). Por um lado, embora faça alusões aos fenômenos socioculturais, o que Cardoso privilegia mesmo é a faceta econômica da globalização, mas ainda assim de modo ambíguo: nesses termos, as mudanças capitalistas contemporâneas aparecem ora como benfazejas, ora como pesadas e ameaçadoras, embora seja o primeiro modo de apresentação que prevalece no mais das vezes - "Seja como for, no entender de Cardoso a globalização nos projeta no limiar de uma nova era" (idem: 63). Por outro lado, não fica patente qual é seu estatuto, pois ela é vista de modos diferentes. Ora como um processo histórico:

\begin{abstract}
"Em algumas sentenças ele [o termo globalização] denota um processo histórico — a totalidade das mudanças que estão transformando o capitalismo em algo ainda parcialmente indistinto, mas que, talvez, venha a constituir uma outra 'qualidade'. Este é o sentido que o conceito adquire, por exemplo, nesta passagem: 'A globalização está longe de ser um fenômeno que avança de modo uniforme no plano internacional. Seu ritmo obedece a movimentos variados. O paradigma financeiro, p. ex., é diferente do comercial. Neste último as resistências são muito maiores...' ". * (Idem: 63).
\end{abstract}

Ora como um estado ou uma configuração da economia internacional:

\begin{abstract}
"Já em outras, o termo globalização é usado para indicar uma configuração, um estado — o conjunto de condições que conferem à economia capitalista contemporânea um ordenamento inédito, como na afirmativa que se segue: 'Durante décadas, os países em desenvolvimento tentaram influenciar ... a construção de uma nova ordem internacional. A verdade é que ... essa nova ordem já estava sendo forjada e hoje atende pelo nome de Globalização, " ** (Idem: 63).
\end{abstract}

Ou então, por fim,

"Em alguns lugares, a globalização é um estado de coisas estabelecido, uma realidade pronta e acabada: 'Queiramos ou não a globalização econômica é uma nova ordem internacional'. Em outros, ela urge coimo um cenário — o desenho que se insinua no horizonte, o qual, em alguma

\footnotetext{
* Aqui Velasco e Cruz cita as pp. 21-22 de O impacto da globalização nos países em desenvolvimento: riscos e oportunidades, conferência lida por Cardoso no México em 20.02.1996.

** A citação usada por Velasco e Cruz provém da mesma conferência mencionada na nota anterior, porém à p. 23.
} 
medida, está ao nosso alcance alterar: '[os governantes] não podem simplesmente ignorar esses condicionantes da realidade contemporânea, [mas] têm o dever de buscar nas contradições e nas inconsistências ... do sistema em gestação estratégias capazes de reafirmar a prioridade do interesse nacional " ${ }^{* * * *}$ (Idem: 63-64).

São variadas, pois, as interpretações que Cardoso tem para lidar com as mudanças capitalistas atuais. Todavia, como sustenta Velasco e Cruz, tais ambigüidades assumem outro aspecto se interpretadas desde o plano político, retórico e pragmático, para o qual os discursos de Cardoso se dirigem. Nesse registro, a referida frouxidão dos conceitos indica uma variação entre "determinismo" e "voluntarismo", frouxidão valiosa, no caso do primeiro termo, quando se trata de desqualificar críticas como cegas às "necessidades do momento", ou então, no caso do segundo, quando se cuida de dar suporte político e econômico a setores determinados da economia nacional, argumentos utilizados conforme a necessidade do momento (Velasco e Cruz, 1998: 67-69).

Seja como for, interessa ressaltar outro ponto, de importância fundamental: na maioria das vezes, Cardoso entende a globalização como força irresistível do capitalismo, e nesse entendimento a Nação, mais uma vez, tem papel diminuto. Desta feita, Cardoso reifica a globalização e ratifica aquela sua concepção do sistema capitalista internacional (que vem desde os tempos dos estudos sobre a dependência) como um problema ou um condicionamento do desenvolvimento capitalista brasileiro aparentemente resolvido. A questão da integração nacional, central para Furtado, dá lugar em Cardoso para a questão de uma integração econômica regional (Mercosul etc.) ou mesmo internacional: a consecução desta como que solucionaria, superando, aquela.

Cumpre notar que esses mesmos aspectos do pensamento recente de Cardoso sintetizados por Velasco e Cruz encontram-se refletidos nalguma medida em outros lugares e ocasiões, especialmente a problemática nacional. Por exemplo, em entrevista concedida em 1996 e publicada em 1997, é nítido como a questão nacional referida às mudanças capitalistas contemporâneas aparece, em Cardoso, como um momento da questão internacional, ou melhor, o âmbito internacional é que deve resolver o nacional (Cardoso, 1997: 29-31). Noutro exemplo, isso é ainda mais claro; primeiro, ele reafirma sua idéia de

\footnotetext{
*** A primeira citação refere-se a Conseqüências sociais da globalização, conferência lida por na Índia em janeiro de 1996, p. 21, e a segunda a $O$ impacto ..., p. 21.
} 
que a humanidade vive um "novo Renascimento" e, depois, instado a responder se o "Brasil continua tendo um 'desenvolvimento dependente associado', Cardoso responde que

"É, continuo com essa tese. Mas isso não significa que não estejamos avançando. Estamos avançando sim, ainda que num quadro que não é definido por nós. O nosso projeto nacional deve ser o da integração regional. Daí a importância do Mercosul e de abrir as portas para o Chile. Não dá para pensar esse novo mundo pensando que o Brasil vai impor as regras ao Mercosul. Acabou a época das hegemonias regionais" (Cardoso, 2000: A 14 e A 15, itálicos meus).

Naturalmente que um estudo rigoroso do pensamento recente de Cardoso demandaria muito mais análises e muito mais material além do que está presente aqui; entretanto, minha intenção não é fazer tal estudo, de modo que o exposto é o bastante para assinalar - ainda que sucintamente - especificamente um aspecto, qual seja, a maneira pela qual Cardoso estrutura sua interpretação do processo de globalização capitalista e como a questão do lugar da Nação no desenvolvimento capitalista brasileiro é aí equacionado. E pelo que se viu, o entendimento de Cardoso hoje segue basicamente aquela mesma trilha apontada no segundo capítulo e na primeira parte deste.

A consolidação da sociedade nacional não era um problema nos estudos sobre a dependência de Cardoso, pois tratava-se apenas de inseri-la, ainda que subordinadamente, no circuito do sistema capitalista internacional. Ora, tal consideração somente poderia ser pacífica se partisse da perspectiva de um capitalismo internacional sem tensões nem crivado de acirradas disputas de poder, quer dizer, somente assim a inserção brasileira no capitalismo poderia ser vista como tranqüila e praticamente assegurada. E, diante do exposto linhas acima, o que é isso se não a compreensão que Cardoso tem hoje da globalização e do lugar da Nação aí? Os antagonismos capitalistas são apenas obstáculos superáveis e a integração da Nação nesse rol é possível e provável, sem impasses. Ou seja, como pretendi sustentar, a visão de Cardoso hoje a respeito do lugar da Nação no desenvolvimento capitalista brasileiro é basicamente aquela dos anos 1960 e 1970. Nesse sentido há, ao menos nesse item, uma continuidade irrefutável.

Posto isso, menos que fazer considerações valorativas sobre esta ou aquela interpretação, este trecho da dissertação pretende apenas indicar como hoje, nas análises que fazem das mudanças capitalistas contemporâneas, Furtado e Cardoso não estão nada mais que mantendo e continuando, na essência, suas abordagens originais sobre o 
desenvolvimento capitalista brasileiro e a questão nacional. Daí que, assim como lá, os referidos autores distanciam-se em pontos fundamentais. A nota forte na visão furtadiana radica na idéia de que a globalização acentua as disparidades econômicas e sociais entre centro e periferia, embora reconheça que um ou outro segmento social e econômico pode auferir vantagens desse processo; em Cardoso, diversamente, a globalização amplia as possibilidades de desenvolvimento ao abrir "janelas de oportunidades”, embora ele reconheça eventuais desigualdades nesse âmbito. Furtado não nega in totum a ocorrência de saldos positivos advindos da integração internacional, todavia ele crê que essa integração somente pode ser efetivada sem riscos políticos, econômicos e sociais se a integração nacional estiver razoavelmente consistente (caso contrário, os "abismos" inter e sobretudo intranacionais só crescerão de tamanho) — ou seja, a integração nacional antes da internacional; por seu turno, Cardoso crê que a integração nacional faz-se como um "momento" da integração internacional, quer dizer, a integração internacional, com suas infinitas possibilidades de ganhos, como que impulsiona e alimenta a integração nacional — efeitos deletérios virão não da integração internacional mas de sua ausência.

Em suma, cada qual a seu modo, Furtado e Cardoso hoje, diante da globalização, utilizam-se do quadro teórico e referencial que cada um montou para estudar e interpretar o desenvolvimento capitalista brasileiro, o que nos possibilita dizer que há uma linha de continuidade seguida num e noutro. Obviamente que não se trata de afirmar que a análise furtadiana atual segue dual-estruturalista tal qual em meados deste século (o que seria ignorar suas modificações, seja de moto próprio, seja incorporando críticas), tanto quanto não se pode tomar Cardoso hoje como teórico dependentista (o que seria não dar o devido peso à injunções e às condições próprias de suas funções política) ${ }^{12}$. Não obstante isso, o principal permanece: apontar que, mantendo-se ligados ou informados por suas teorizações anteriores, Furtado e Cardoso reproduzem atualmente, e quiçá da maneira a mais aguda,

\footnotetext{
${ }^{12}$ Em seu texto já citado, Velasco e Cruz também alerta para os desdobramentos apressados que as semelhanças entre o Cardoso de "ontem" e o de "hoje" podem suscitar: "Esta constatação [das semelhanças] poderia nos incitar ao comentário de que Cardoso pratica hoje, como político, a dependência que ele teorizou, anos atrás, como sociólogo. Mas essa afirmativa não seria de todo justificada. A 'teoria da dependência' surgiu num ponto determinado no tempo e no espaço. Pelas condições históricas que cercaram o seu aparecimento, ela veio associada a conteúdos político-ideológicos de caráter emancipatório, que se expressavam nas consequiências práticas que dela se extraíam, bem como nos termos em que era vasada [sic]. Mas a dimensão programática não lhe era essencial. Como guia para a análise de 'situações concretas', ela deveria poder iluminar, tanto os desenvolvimentos históricos tendentes à superação da dependência, quanto aqueles que viessem reforçar esta última em suas formas mais perversas” (Velasco e Cruz, 1998: 69).
} 
aquela distinção - ou ruptura — que venho tentando frisar durante toda esta dissertação. Distinção que, se é que alguma vez não o foi, é hoje sobretudo de cunho político — de decisões e opções políticas. 


\section{CONSIDERAÇÕES FINAIS}

O objetivo que pautou esta dissertação foi o de analisar as interpretações do desenvolvimento capitalista brasileiro fornecidas por Celso Furtado (através de seu dualestruturalismo) e por Fernando Henrique Cardoso (por intermédio de seus estudos sobre a dependência), dois dos principais momentos, se não os dois principais, da produção brasileira e latino-americana nas Ciências Sociais desde os anos 1950. Mais precisamente, o que procurei perseguir foi o lugar da Nação — da sociedade nacional, do desenvolvimento nacional, do Estado nacional - em cada uma das referidas interpretações, tomadas a partir de seus escritos mais importantes e percucientes, sem a pretensão de esgotá-las. Partindo-se da idéia de que existem continuidades e rupturas entre o pensamento cepalino-furtadiano e os estudos dependentistas, o que aqui ficou evidenciado é que o tema da Nação constitui justamente um desses pontos de ruptura, perceptível mesmo nos trabalhos mais recentes dos autores.

Vimos como Furtado, partindo de um amplo leque de influências e interlocuções (nem sempre admitidos), constrói seu esquema interpretativo do desenvolvimento capitalista brasileiro e, junto com ele, a noção de subdesenvolvimento, da mesma maneira que vimos como a idéia de Nação percorre toda a obra furtadiana e é sua preocupação primordial. Daí que constituição do Brasil como Nação e superação do subdesenvolvimento fundem-se em Furtado, conferindo notável radicalidade a sua teoria (posto que a própria ordenação do sistema capitalista, dividido entre um centro e uma periferia, deveria ser necessariamente questionado). Essa mesma preocupação e esse mesmo modo de interpretar o desenvolvimento capitalista brasileiro está nos trabalhos mais recentes de Furtado, que ali

deixa claro o que já estava patente em seus escritos do "auge do desenvolvimento": a centralidade da questão nacional em seu pensamento.

Cardoso inscreve-se na vaga crítica que sucedeu o apogeu do dual-estruturalismo e que ganhou força com as "promessas não cumpridas" pelo desenvolvimentismo a partir de 
meados dos anos 1960. Impulsionado pelos impasses e equívocos dual-estruturalistas (dos quais Furtado não escapou) e por um contexto histórico propício, Cardoso (a princípio em conjunto com Enzo Faletto) propôs a noção de dependência como mais adequada para analisar as relações entre países capitalistas. Daí que teríamos um desenvolvimento dependente e associado, isto é, a possibilidade de lograr desenvolvimento sem que os laços de dependência tivessem necessariamente que ser rompidos. Há Nação no esquema interpretativo de Cardoso - ele mesmo diz que seu interesse refere-se aos Estados nacionais - , porém essa Nação não é problematizada, quer dizer, sua inserção no sistema capitalista internacional é entendida como pacífica e passiva. Esta perspectiva, cunhada nos estudos sobre a dependência, não deixa de se refletir nas atividades político-partidárias atuais de Cardoso, embora, volto a dizer, não seja possível estabelecer uma linha direta e reta entre o sociólogo e o político e elidir as características de cada momento.

Depois de todo esse itinerário, torna-se ainda mais clara a distinção que há entre Furtado e Cardoso sob o aspecto investigado nesta dissertação. Ao passo que a interpretação que Furtado propõe do desenvolvimento capitalista brasileiro converte-se numa teoria da superação do subdesenvolvimento, a de Cardoso pode ser lida como uma teoria da inserção nacional subordinada ao sistema capitalista internacional. Por certo há pontos de continuidade entre Furtado e Cardoso, porém este especificamente é um no qual eles se afastam imensamente, tanto ontem quanto hoje.

De qualquer modo, não há como não aquilatar os méritos das referidas interpretações e, principalmente, de seus produtos, as noções de subdesenvolvimento e de dependência. Abordagens bastante profícuas que colaboraram sobremaneira para o descortino dos caminhos capitalistas brasileiros e latino-americanos e que hoje, diante da assim chamada globalização, reassumem a relevância que esteve um tanto encoberta até há alguns anos. Afinal, como pensar a posição do Brasil neste mundo globalizado? Não podem as interpretações aqui vistas ajudar nalguma medida? Um retorno às noções de subdesenvolvimento e de dependência não seria um bom começo de análise? Naturalmente que o modus operandi capitalista vem se metamorfoseando desde que os estudos furtadianos e os dependentistas, na vertente de Cardoso, foram feitos, e nesse sentido não há como não levar essa diferença de contextos em conta; porém, tal retorno seja talvez salutar por nos lembrar daquilo que por vezes nos esquecemos: que, apesar dos avanços, 
nunca deixamos de ser subdesenvolvidos e dependentes. Não se trata de propor uma visão derrotista - "fracassomaníaca" — do mundo e de nosso lugar nele, mas sim de tomar cuidado para não incorrer em arroubos demasiadamente otimistas. Desta perspectiva, nosso passado nunca pesou tanto quanto agora.

Talvez a idéia de um desenvolvimento capitalista periférico e, especialmente, de um desenvolvimento capitalista específico, peculiar, que segue rota diversa que aquela seguida pelos países centrais, que Furtado matizou exemplarmente, talvez esse seja um bom ponto de partida para a compreensão do desenvolvimento capitalista brasileiro hoje. Tanto mais porque, como vimos, o sistema capitalista internacional parece acentuar suas disparidades e desigualdades de um modo que dificulta a possibilidade de destruição dos grilhões do subdesenvolvimento como estava contida no esquema original do dual-estruturalismo. A pergunta que fica é se haverá espaço ainda para o exercício dessa singularidade brasileira, um espaço que vá além de um campo de valorização do capital para global players. Se é certo que há muito deixamos para trás a categoria de economia primário-exportadora, igualmente certo é que não conseguimos atingir um patamar sócio-econômico que nos permita acreditar havermos ultrapassado de todo as barreiras do subdesenvolvimento. Daí que, sem sermos nem uma coisa nem outra, a noção de um percurso sui generis seja uma boa pista a ser seguida.

Outra possibilidade é, como fez Singer (1998), aventar uma modalidade de dependência ligada à financeirização do capitalismo, uma "dependência desejada". Dado o primado das finanças no capitalismo contemporâneo, e posto que essa forma de capital implica em sérios constrangimentos às atividades regulatórias do Estado nacional, essa forma de dependência seria desejada porque assim abre caminho para fluxos internacionais de capitais de que mais e mais os países, sobretudo os periféricos, necessitam e estão a serviço ${ }^{1}$. Há que se pensar, contudo, que tipo de Estado nacional essa "dependência

\footnotetext{
1 "Do ponto de vista da situação de dependência, esta deixou de ser tolerada para se tornar desejada. Os governos de todos os países — desenvolvidos, semi-desenvolvidos ou poucos desenvolvidos — passaram a depender crescentemente do capital privado globalizado. Esta dependência é algo menor apenas nas grandes potências, cujas autoridades monetárias dispõem de algum controle sobre a taxa básica de juros e sobre o montante de crédito bancário e extra-bancário, podendo com estes instrumentos condicionar a movimentação dos capitais privados.(...) A diferença entre a dependência consentida — absolutamente geral no fim do século XIX e hoje vigente apenas nos países mais atrasados - e a dependência desejada é que a primeira prescinde da industrialização e da urbanização e a última visa completar estes processos para incorporar as nações dependentes ao $1^{\circ}$. Mundo. Não há, portanto, qualquer volta possível a uma normalidade liberal como a que vigorou no século XIX. A nova dependência do grande capital globalizado é desejada porque é vista como
} 
desejada" enseja, pois, como vimos, a noção mesma de dependência traz consigo a necessidade de um Estado nacional - sem este, fazendo a mediação entre os interesses externos e internos, teríamos qualquer outra relação entre países capitalistas centrais e os periféricos, menos dependência. De qualquer maneira, permanece a intenção de que a noção de dependência poderia talvez prestar bons serviços à compreensão desenvolvimento capitalista brasileiro.

Enfim, parece-me irrefutável a importância e a percuciência das interpretações de Furtado e de Cardoso para a análise do desenvolvimento brasileiro e, mais amplamente, para a explicação do Brasil. Daí que estudá-las e explorá-las é um passo necessário, esmiuçando suas tensões, impasses, avanços e, se é possível falar assim, seus erros e acertos. Foi o que tentei fazer aqui. Se esta dissertação conseguir contribuir para esse passo, minimamente que seja, terá cumprido amplamente sua pretensão de fundo. 


\section{BIBLIOGRAFIA}

BATISTA Jr., Paulo N. (1997a). Mitos da globalização. São Paulo: Instituto de Estudos Avançados/USP, Coleção Documentos n ${ }^{\circ}$ 52, Série Assuntos Internacionais.

(1997b). "O círculo de giz da 'globalização"”. Novos Estudos Cebrap. São Paulo, Cebrap, $\mathrm{n}^{\circ} .49$.

BECK, Ulrich (1998). ¿Qué es la globalización? Falacias del globalismo, respuestas a la globalización. Barcelona: Paidós.

BELLUZZO, Luís Gonzaga de M. (1995). "O declínio de Bretton Woods e a emergência dos 'mercados globalizados' ". Economia e Sociedade. Campinas, n’ 04.

(1997). "Dinheiro e as transfigurações da riqueza", In TAVARES, Maria da C. \& FIORI, José Luís (org.). Poder e dinheiro: uma economia política da globalização. $5^{\text {a }}$. ed., Petrópolis: Vozes, 1997.

BIELSCHOWSKY, Ricardo (1989). "Formação econômica do Brasil: uma obra-prima do estruturalismo cepalino", In Revista de Economia Política. São Paulo, vol. 9, n. 4, Outubro-Dezembro de 1989. Este texto consta como apêndice, ligeiramente modificado, em Bielschowsky (1996).

(1996). Pensamento econômico brasileiro: o ciclo ideológico do desenvolvimentismo. $3^{\text {a }}$. ed., Rio de Janeiro: Contraponto.

BRAGA, José Carlos de S. (1993). “A financeirização da riqueza: a macroestrutura financeira e a nova dinâmica dos capitalismos centrais". Economia e Sociedade. Campinas, $\mathrm{n}^{\circ} .2$.

(1997). "Financeirização global: o padrão sistêmico de riqueza do capitalismo contemporâneo", In TAVARES, Maria da C. \& FIORI, José Luís (org.). Poder e dinheiro: uma economia política da globalização. $5^{\text {a }}$. ed., Petrópolis: Vozes, 1997.

CARDOSO, Fernando Henrique (1964). Empresário industrial e desenvolvimento econômico no Brasil. São Paulo: Difusão Européia do Livro.

(1971). “' 'Teoria da dependência' ou análises concretas de situações de dependência?”. Estudos Cebrap. São Paulo, Cebrap, nº 01. 
(1973). O modelo político brasileiro e outros ensaios. $2^{\text {a }}$. ed., São Paulo: Difusão Européia do Livro.

(1974). "As contradições do desenvolvimento-associado". Estudo Cebrap. São Paulo, Cebrap, $\mathrm{n}^{\circ} .08$.

(1975a). Autoritarismo e democratização. $2^{\text {a }}$. ed., Rio de Janeiro: Paz e Terra.

(1975b). "Notas sobre o estado atual dos estudos sobre a dependência", In Cadernos Cebrap: Notas sobre Estado e dependência. São Paulo, Cebrap/Brasiliense, $\mathrm{n}^{\circ} .11$.

(1976). "Estatização e autoritarismo esclarecido: tendências e limites". Estudos Cebrap. São Paulo, Cebrap, $\mathrm{n}^{\circ} .15$.

(1979). "Hegemonia burguesa e independência econômica: raízes estruturais da crise política brasileira", In Furtado (1979).

(1980). "El atolladero de los regímenes autoritarios: el caso de Brasil". Revista Mexicana de Sociología. México-DF, ano XLII, vol. XLII, ${ }^{\circ}$. 03, Julho-Setembro de 1980.

(1993). As idéias e seu lugar: ensaios sobre as teorias do desenvolvimento. $2^{\mathrm{a}}$. ed., Petrópolis: Vozes.

(1997). "Estamos reorganizando o capitalismo brasileiro" (entrevista a Brasílio Sallum Jr.). Lua Nova. São Paulo, nº 39.

(2000). Entrevista a Folha de S.Paulo. São Paulo, edição de 27.05.2000, p. A 14.

\& FALETTO, Enzo (1973). Dependência e desenvolvimento na América Latina: ensaio de interpretação sociológica. $2^{\mathrm{a}}$. ed., Rio de Janeiro: Zahar.

$\&$ (1977). "Estado y proceso político en América Latina". Revista Mexicana de Sociología. México, ano 39, vol. 39, nº. 02, Abril-Junho de 1977.

CEPÊDA, Vera Alves (1998). Raízes do pensamento político de Celso Furtado: desenvolvimento, nacionalidade e Estado democrático. São Paulo, Dissertação de Mestrado, Departamento de Ciências Políticas, FFLCH/USP.

CHESNAIS, François (1995). "A globalização e o curso do capitalismo de fim-de-século". Economia e Sociedade. Campinas, IE/Unicamp, $\mathrm{n}^{\circ} .5$. (1996). A mundialização do capital. São Paulo: Xamã.

(1997). "A emergência de um regime de acumulação predominantemente financeiro". Praga - estudos marxistas. São Paulo, Hucitec, $\mathrm{n}^{\circ} .3$. 
CHILCOTE, Ronald H. (1983). "Teorias reformistas e revolucionárias de desenvolvimento e subdesenvolvimento", In Revista de Economia Política. São Paulo, vol. 3, n. 3, Julho-Setembro de 1983.

FALETTO, Enzo (1998). Los años sesenta y el tema de la dependencia. Texto apresentado no seminário "Teoria da dependência: 30 anos depois", Instituto de Estudos Avançados, Universidade de São Paulo, São Paulo/SP, 15 e 16 de Junho de 1998.

FAUSTO, Ayton (1971). "La nueva situación de dependencia y el análisis sociopolítico de Theotônio dos Santos". Revista latinoamericana de Ciências Sociales. Santiago do Chile, nº ${ }^{\circ}$ 1-2, Junho-Dezembro de 1971.

FERNANDES, Florestan (1978). Apontamentos sobre a 'teoria do autoritarismo'. São Paulo: Hucitec.

FIGUEIREDO, Ferdinando (1990). "As transformações do pós-guerra e o pensamento econômico da CEPAL", In Revista de Economia Política. São Paulo, vol. 10, n .4 (40), Outubro-Dezembro de 1990.

FIORI, José Luís (1993). Para uma Economia Politica do Estado brasileiro. São Paulo: IESP/FUNDAP (Texto para discussão/IESP, 11).

(1995). Em busca do dissenso perdido: ensaios críticos sobre a festejada crise do Estado. Rio de Janeiro: Insight.

(1997). "Globalização, hegemonia e império", In TAVARES, Maria da C. \& FIORI, José Luís (org.). Poder e dinheiro: uma economia política da globalização. $5^{\mathrm{a}}$. ed., Petrópolis: Vozes, 1997.

FURTADO, Celso (1963). Desenvolvimento e subdesenvolvimento. $2^{\text {a }}$. ed., Rio de Janeiro: Fundo de Cultura.

(1964). Dialética do desenvolvimento. $2^{\mathrm{a}}$. ed., Rio de Janeiro: Fundo de Cultura.

(1968). Subdesenvolvimento e estagnação na América Latina. 2ª . ed., Rio de Janeiro: Civilização Brasileira.

(1971). Teoria e politica do desenvolvimento econômico. $4^{\mathrm{a}}$. ed., São Paulo: Editora Nacional. (1974). O mito do desenvolvimento econômico. Rio de Janeiro: Paz e Terra. (org.) (1979). Brasil: tempos modernos. 3ª ed., Rio de Janeiro: Paz e Terra. (1980). Pequena introdução ao desenvolvimento: enfoque interdisciplinar. $2^{\mathrm{a}}$. ed., São Paulo: Ed. Nacional. 
(1982). Formação econômica do Brasil. 18ª ed., São Paulo: Editora Nacional. Terra.

(1984). Cultura e desenvolvimento em época de crise. Rio de Janeiro: Paz e

(1985). A fantasia organizada. Rio de Janeiro: Paz e Terra.

(1989). A fantasia desfeita. Rio de Janeiro: Paz e Terra.

(1992a). Brasil: a construção interrompida. $2^{\text {a }}$. ed., Rio de Janeiro: Paz e Terra.

(1992b). "Globalização das estruturas econômicas e identidade nacional", In Estudos Avançados. São Paulo, 6(16), 1992.

(1992c). Entrevista. Folha de S.Paulo. São Paulo, 19.07.92, pp. 6-10 e 6-11.

(1992d). "O subdesenvolvimento revisitado". Economia e sociedade. Campinas, IE/Unicamp, $\mathrm{n}^{\circ} .01$.

(1994). "A superação do subdesenvolvimento", In Economia e Sociedade. Campinas, IE/Unicamp, n. 3, Dezembro de 1994.

(1995). "O pensamento econômico latino-americano - entrevista de Celso Furtado a Carlos Mallorquín". Novos Estudos Cebrap. São Paulo, Cebrap, n . 41, 1995.

(1998). O capitalismo global. São Paulo: Paz e Terra.

(2000). Reflexões sobre a crise brasileira. Texto apresentado no seminário internacional "Novos paradigmas de desenvolvimento", São Paulo, Universidade de São Paulo, 13 e 14 de Junho de 2000.

GOLDENSTEIN, Lídia (1994). Repensando a dependência. Rio de Janeiro: Paz e Terra.

GONÇALVES, Reinaldo (1994). Ô abre-alas: a nova inserção do Brasil na economia mundial. Rio de Janeiro: Relume-Dumará.

GUIMARÃES, Maria Eugênia (1993). Modernização brasileira no pensamento de Celso Furtado. Campinas, Dissertação de Mestrado, Departamento de Ciências Sociais, IFCH/Unicamp.

(1999). Celso Furtado: a utopia da razão - um estudo sobre o conceito de subdesenvolvimento. São Paulo, Tese de Doutorado, Departamento de Sociologia, FFLCH/USP.

GURRIERI, Adolfo (1982). “La economía política de Raúl Prebisch”, In Prebisch (1982). 
HARVEY, David (1993). A condição pós-moderna: uma pesquisa sobre as origens da mudança cultural. $2^{\text {a }}$. ed., São Paulo: Loyola.

HIRST, Paul \& THOMPSON, Grahame (1998). Globalização em questão: a economia internacional e as possibilidades de governabilidade. Petrópolis: Vozes.

HODARA, Joseph (1987). "Orígenes de la CEPAL”, In Comércio Exterior. México, vol. 37, $\mathrm{n}^{\circ}$. 5, Maio de 1987.

IGLÉSIAS, Francisco (1971). "Celso Furtado: pensamento e ação". In: . História e ideologia. São Paulo: Perspectiva.

KAY, Cristóbal (1991). "Reflections on the Latin American contribution to Development Theory". Development and Change. Londres e Nova Déli, vol. 22, $\mathrm{n}^{\circ} .01$.

LÊNIN, Vladimir I. (1971). El imperialismo, etapa superior del capitalismo: ensaio popular. Buenos Aires: Anteo.

LOVE, Joseph (1990). "The origins of dependency analysis". Journal of Latin American studies. Cambridge, volume 22, parte I, Fevereiro de 1990.

MACEDO, Bernardo Gouthier (1994). As idéias de Raúl Prebisch sobre a industrialização periférica (1949-1954). Campinas, Dissertação de Mestrado, IE/Unicamp.

MACHADO, Luiz Toledo (1999). "A teoria da dependência na América Latina”. Estudos Avançados. São Paulo, nº 35.

MAGALHÃES F ., Francisco de B. B. (1998). "A hegemonia neoliberal: fim da história ou mito do eterno retorno?". Plural-Revista do curso de pós-graduação em Sociologia da FFLCH/USP. São Paulo, $\mathrm{n}^{\circ} .5$.

MALLORQUÍN, Carlos (1993). La idea del subdesarrollo: el pensamiento de Celso Furtado. México, Tesis doctoral, Estudios Latinoamericanos, Universidad Nacional Autónoma de México.

(1994). "Lucha, poder y desencanto: los primeros tiempos de Celso Furtado", In Marini \& Millán (1994).

(1998). "Celso Furtado et le structuralisme en économie". Cahiers du Brésil Contemporain. Paris, $\mathrm{n}^{\circ} \mathrm{s}$. 33/34. (Número dedicado a Celso Furtado: "Le development, qu'est-ce? L'apport de Celso Furtado").

MANTEGA, Guido (1989). "Celso Furtado e o pensamento econômico brasileiro". Revista de Economia Política. São Paulo, vol. 9, n . 4, Outubro-Dezembro de 1989.

(1995). A economia política brasileira. $8^{\text {a }}$. ed., Petrópolis: Vozes. 
MARINI, Ruy Mauro (1969). Subdesarrollo y revolución. México-DF: Siglo Veintiuno.

(1972). "Brazilian subimperialism". Monthly review. EUA, vol. 02, n. 09, Fevereiro de 1972.

(1978). "Las razones del neodesarrollismo (respuesta a F.H. Cardoso y J. Serra)”. Revista mexicana de Sociología. México-DF, ano XL, vol. XL, número extraordinário (E), 1978.

(1979). Dialéctica de la dependencia. 4a . ed., México-DF: Ediciones Era.

(1994). "La crisis del desarrollismo”, In Marini \& Millán (1994).

\& MILLÁN, Márgara (coord.) (1994). La teoría social latinoamericana. México: Ediciones El Caballito (Tomo II: Subdesarrollo y dependencia).

MELLO, João Manuel Cardoso de (1991). O capitalismo tardio: contribuição à revisão crítica da formação e do desenvolvimento da economia brasileira. 8 . ed., São Paulo: Brasiliense.

MORAES, Reginaldo de (1995). Celso Furtado: o subdesenvolvimento e as idéias da CEPAL. São Paulo: Ática. Trata-se da publicação, algo modificada, da tese de doutorado do autor.

MYRDAL, Gunnar (1960). Teoria econômica e regiões subdesenvolvidas. Rio de Janeiro: Instituto Superior de Estudos Brasileiros (ISEB). Originalmente trabalho de 1956.

(1962). O Estado do futuro: o planejamento econômico nos Estados de bemestar e suas implicações internacionais. Rio de Janeiro: Zahar. Originalmente trabalho de 1959.

NURKSE, Ragnar (1970). Problems of capital formation in underdeveloped countries and patterns of trade and development. New York: Oxford University Press. Trabalho de 1953.

O'BRIEN, Philip J. (1975). "A critique of latin american theories of dependency". In: OXAAL, Ivar et al. (org.). Beyond the sociology of development: economy and society in Latin America and Africa. Londres: Routledge \& Kegan Paul, 1975.

(1985). "Dependency revisited". In: ABEL, Christopher \& LEWIS, Carol M. (org.). Latin America, economic imperialism and the State: the political economy of the external connection from independence to the present. Londres: Athlone Press, 1985.

OLIVEIRA, Francisco de (1976). "A economia brasileira: crítica à razão dualista", In Seleções Cebrap 1. 2a . ed., São Paulo: Brasiliense/Edições Cebrap. 
(1983). "A navegação venturosa" (Introdução), In OLIVEIRA, Francisco de (org.). Celso Furtado: economia. São Paulo: Ática. (Coleção Grandes Cientistas Sociais, v. 33.).

(1986). "Celso Furtado e o pensamento econômico brasileiro", In Moraes, Reginaldo de et al. Inteligência brasileira. São Paulo: Brasiliense, 1986.

(1997). "Viagem ao olho do furacão: Celso Furtado e o desafio do pensamento autoritário brasileiro". Novos Estudos Cebrap. São Paulo, Cebrap, nº 48, 1997.

(1998). Periferia, subdesenvolvimento e radicalização anti-democrática. Texto preparado para o seminário "Repensando o capitalismo dependente: uma homenagem a Florestan Fernandes", na Universidade Federal de São Carlos, São Carlos (SP), de 31 de agosto a 04 de setembro de 1998. Manuscrito.

OSORIO, Jaime (1994). "Fuentes e tendencias de la teoría de la dependencia", In Marini \& Millán (1994).

PALMA, Gabriel (1987). "Dependencia y desarrollo: una visión crítica". In: SEERS, Dudley (org.). La teoría de la dependencia: una revaluación crítica. México-DF: Fondo de cultura económica. (Publicado anteriormente em versão menor como "Dependency: a formal theory of underdevelopment or a methodology for the analysis of concrete situations of underdevelopment?" World Development. Vol. 6, $\left.\mathrm{n}^{\circ} \mathrm{s} .7-8,1978\right)$.

PÉCAULT, Daniel (1998). "Celso Furtado et le politique: l'ecrivain comme un 'penseur' ". Cahiers du Brésil Contemporain. Paris, $\mathrm{n}^{\circ} \mathrm{s}$. 33/34. (Número dedicado a Celso Furtado: "Le development, qu'est-ce? L'apport de Celso Furtado").

PORTANTIERO, Juan Carlos (1989). “O marxismo latino-americano”. In: HOBSBAWM, Eric (org.). História do marxismo. 2 ${ }^{\mathrm{a}}$. ed., Rio de Janeiro: Paz e Terra, 1989.

PREBISCH, Raúl (1982). La obra de Prebisch en la CEPAL (selección de Adolfo Gurrieri). México: Fondo de Cultura Económica (2 volumes).

REINO, Jayme Estay (1994). "La concepción inicial de Raúl Prebisch y sus transformaciones", In Marini \& Millán (1994).

RODRÍGUEZ, Octavio (1981). Teoria do subdesenvolvimento da CEPAL. Rio de Janeiro: Forense-Universitária.

(1988). "O pensamento da CEPAL: síntese e crítica", In PEDRÃO, Fernando (org.). $O$ pensamento da CEPAL. Salvador: Organização dos Estados Americanos/Universidade Federal da Bahia/Ianamá, 1988.

\& BURGEÑO, Oscar \& HOUNIE, Adela \& PITTALUGA, Lucía (1995). 
"CEPAL: velhas e novas idéias". Economia e Sociedade. Campinas, $\mathrm{n}^{\circ} .5$ Dezembro de 1995.

ROSTOW, Walt W. (1978). Etapas do desenvolvimento econômico: um manifesto nãocomunista. 6 . ed., Rio de Janeiro: Zahar. Originalmente trabalho de 1959.

SADER, Emir (1997). "Nós que amávamos tanto O Capital", In O poder, cadê o poder?: ensaios para uma nova esquerda. São Paulo: Boitempo.

SAMPAIO Jr., Plínio S. de Arruda (1997). Entre a Nação e a barbárie: uma leitura das contribuições de Caio Prado Jr., Florestan Fernandes e Celso Furtado à crítica do capitalismo dependente. Campinas, Tese de Doutorado, IE/Unicamp.

(1999). “O impasse da formação nacional”, In Fiori, José Luís (org.). Estados e moedas no desenvolvimento das nações. Petrópolis: Vozes, 1999.

SANTOS, Theotônio dos (1969a). Socialismo o fascismo: el dilema latinoamericano. Santiago do Chile: Prensa Latinoamericana.

(1969b). "El nuevo carácter de la dependencia". In: MAR, José Matos (org.). La crisis del desarrollismo y la nueva dependencia. Buenos Aires: Amorrortu Editores, 1969.

(1969c). "La crisis de la teoría del desarrollo y las relaciones de dependencia en América Latina". In: JAGUARIBE, Hélio et al. La dependencia político-económica de América Latina. México-DF: Siglo Veintiuno, 1969.

(1970). "The structure of dependence". The american economic review. EUA, vol. LX, nº. 01, Março de 1970.

(1977). "Socialismo y fascismo en América Latina hoy". Revista mexicana de Sociología. México-DF, ano 39, vol. 39, nº. 01, Janeiro-Março de 1977.

(1994). "O desenvolvimento latino-americano: passado, presente e futuro. Uma homenagem a André Gunder Frank". Humanas. Porto Alegre, v. 17, n's. 1/2, Janeiro/Dezembro de 1994.

(1998). A teoria da dependência: um balanço histórico e teórico. Texto apresentado no seminário "Teoria da dependência: 30 anos depois", Instituto de Estudos Avançados, Universidade de São Paulo, São Paulo/SP, 15 e 16 de Junho de 1998.

SANTOS*, Maria Odete (1998). Nação e mundialização no pensamento de Celso Furtado. Campinas, Tese de Doutorado, Departamento de Sociologia, IFCH/Unicamp. 
SERRA, José \& CARDOSO, Fernando Henrique (1978). "Las desventuras de la dialéctica de la dependencia”. Revista mexicana de Sociología. México-DF, ano XL, vol. XL, número extraordinário (E), 1978.

SINGER, Paul (1996). "Perspectivas de desenvolvimento da América Latina". Novos Estudos Cebrap. São Paulo, Cebrap, ${ }^{\circ} .44$.

(1997). "Globalização positiva e globalização negativa: a diferença é o Estado". Novos Estudos Cebrap. São Paulo, Cebrap, nº 48.

(1998). De dependência em dependência: consentida, tolerada e desejada. Texto apresentado no seminário "Teoria da dependência: 30 anos depois", Instituto de Estudos Avançados, Universidade de São Paulo, São Paulo/SP, 15 e 16 de Junho de 1998.

STAVENHAGEN, Rodolfo (1974). "Sete teses equivocadas sobre a América Latina", In DURAND, José Carlos Garcia (org.). Sociologia do desenvolvimento. $2^{\text {a }}$. ed., Rio de Janeiro: Zahar, 1974.

SUNKEL, Osvaldo \& PAZ, Pedro (1970). El subdesarrollo latinoamericano y la teoria del desarrollo. México: Siglo XXI.

TEIXEIRA, Aloísio (1994). O ajuste impossível. Rio de Janeiro: Editora da UFRJ.

VELASCO E CRUZ, Sebastião C. (1998). Idéias do poder: dependência e globalização no discurso recente de Fernando Henrique Cardoso. Texto apresentado no seminário "Teoria da dependência: 30 anos depois", Instituto de Estudos Avançados, Universidade de São Paulo, São Paulo/SP, 15 e 16 de Junho de 1998.

WARREN, Bill (1973). "Imperialism and capitalist industrialization". New left review. EUA, $n^{\circ} .81,1973$.

WEFFORT, Francisco Corrêa (1971). "Notas sobre a 'teoria da dependência': teoria de classe ou ideologia nacional?’. Estudos Cebrap. São Paulo, Cebrap, n . 01, 1971. 